\title{
Collateral Incentives to Arrest
}

\author{
Elina Treyger*
}

\section{INTRODUCTION}

Alonzo King was convicted of rape as a result of a match between crime scene DNA and a DNA sample taken at his arrest for an unrelated assault. ${ }^{1}$ In Maryland v. King, the Supreme Court upheld the law that authorized the collection of King's DNA. Writing for the majority, Justice Kennedy emphasized the security-enhancing potential of DNA screening at arrest for even minor crimes:

[p]eople detained for minor offenses can turn out to be the most devious and dangerous criminals. Hours after the Oklahoma City bombing, Timothy McVeigh was stopped by a state trooper who noticed he was driving without a license plate. Police stopped serial killer Joel Rifkin for the same reason. One of the terrorists involved in the September 11 attacks was stopped and ticketed for speeding just two days before hijacking Flight 93 .

A vocal advocate of involving local law enforcement in federal immigration enforcement, Kris Kobach, similarly pointed out that several of the 9/11 terrorists had contacts with local law enforcement, after they had violated the conditions of their visas. ${ }^{3}$ Were police able to access databases that contained information about these individuals, they might

\footnotetext{
* Assistant Professor, George Mason University. This article benefited from comments and conversations with Aaron Chalfin, Rachel Harmon, Orin Kerr, Jason Kreag, Craig Lerner, Charles Loeffler, Eric Miller, Daniel Morales, Murat Mungan, Jeffrey Parker, Michael Rich, Stephen Rushin, Laurent Sacharoff, David Schleicher, Nirej Sekhon, Seth Stoughton, and Susan Yeh. I am also grateful to the participants of the 2013 Virginia Junior Faculty Forum, the 2013 Manne Faculty Forum, CrimFest 2014, and the DC area criminal law professors' scholarly gathering for their input. Abby Uzupis and Catherine Burke provided superior research assistance.

1. Maryland v. King, 133 S. Ct. 1958, 1965 (2013).

2. Id. at 1971 (Kennedy, J., concurring) (quoting Florence v. Bd. of Chosen Freeholders, 132 S. Ct. $1510,1520(2012))$.

3. Kris W. Kobach, The Quintessential Force Multiplier: The Inherent Authority of Local Police to Make Immigration Arrests, 69 ALA. L. REV. 179, 188 (2005) ("Had the federal government possessed information regarding the hijackers' immigration violations and possible terrorist connections, and had that information been distributed to police officers via the NCIC system, the terrorist plot that claimed nearly 3,000 lives might have been derailed." (footnote omitted)).
} 
have discovered that the individual they detained for a traffic violation was also a dangerous criminal or a deportable non-citizen. With these discoveries, made possible by integrating disparate data sources, disasters would be averted, crimes solved, and the rule of law vindicated.

The rise of increasingly encompassing and interoperable databases presents a tantalizing opportunity to combine criminal law enforcement with other public policy goals. ${ }^{4}$ These databases raise important questions regarding privacy and expanding government surveillance, which have attracted growing scholarly attention. ${ }^{5}$ Making these new tools available to state agents upon arrest also raises questions about their influence on the exercise of the arrest power. Scholars have noted that access to such databases creates potential for police abuse of discretion, notably with regard to racial inequalities. ${ }^{6}$ This Article advances this discussion. It situates the problems posed by on-arrest screening regimes in the broader context of the proper use and misuse of the discretionary authority to arrest. It defines a category of improper influences on arrest decisions-"collateral incentives to arrest"- that are of particular concern. And it identifies what precisely is objectionable about collateral incentives as a matter of normative legal principles and as a practical matter, using two illustrative on-arrest screening regimes, Secure Communities and DNA collection laws. Under Secure Communities, fingerprints taken at arrest by any local law enforcement agency (LEA) are automatically screened against the Department of Homeland Security's (DHS) database of known and potential immigration violators. ${ }^{7}$ Federal and state DNA collection laws provide for the involuntary collection of DNA samples from some arrestees, which are screened against databases containing DNA samples from arrestees and convicts as well as forensic samples from unsolved crime scenes.

4. See Margaret Hu, Biometric ID Cybersurveillance, 88 IND. L.J. 1475 (2013) (exploring the rise of mass biometric databases and their expanding uses). The FBI's Criminal Justice Information Services (CJIS) promises that due to its ongoing data gathering and processing efforts, "[t]he world's largest repository of criminal fingerprints and history records is being searched in a flash by investigators and police professionals working to catch crooks and terrorists." Criminal Justice Information Services, FBI, http://www.fbi.gov/about-us/cjis (last visited Apr. 22, 2015).

5. See, e.g., Laura K. Donohue, Technological Leap, Statutory Gap, and Constitutional Abyss: Remote Biometric Identification Comes of Age, 97 MINN. L. ReV. 407, 412-14 (2012); Christopher Slobogin, Panvasive Surveillance, Political Process Theory, and the Nondelegation Doctrine, 102 GEO. L.J. 1721 (2014).

6. See, e.g., Kevin Lapp \& Joy Radice, A Better Balancing: Reconsidering Pre-Conviction DNA Extraction from Federal Arrestees, 90 N.C. L. REV. ADDENDUM 157, 166 n.62 (2012).

7. See infra notes $40-45$ and accompanying text. 
Programs such as Secure Communities and laws such as those authorizing DNA collection on arrest offer collateral benefits-some desirable result beyond prosecution for the crime of arrest. That is, an arrest by local LEAs anywhere in the country now carries with it the potential of promptly identifying and deporting immigration violators. And an arrest for a qualifying offense in most states now carries with it the potential to solve a cold case or deter a recidivist offender from future crimes for which DNA might be recovered. Collateral benefits provide law enforcers with collateral incentives that are relevant to the discretionary decision to arrest particular individuals. The incentives set up by these screening regimes are "collateral" because (i) they hold out benefits that are largely uncorrelated with the suspect's probability of guilt for the crime of arrest, and (ii) the probability of reaping these benefits is largely independent of the suspect's guilt of, or prosecution for, the crime of arrest. To the extent law enforcers value the prospect of screening, the automatic availability of such makes arrests of some suspects more attractive than others, for reasons unconnected with their guilt, culpability, or the state's interest in pursuing charges for the crime of arrest.

This Article provides a framework that defines collateral incentives, distinguishes them from less distortive influences on arrest decisions, and generates expectations about their empirical effects on arrest patterns. Scholarly attention to the police use of discretion is, of course, not new; Stephanos Bibas, for instance, recently remarked that police discretion is not in itself a problem, but "unchecked, unreviewable, and potentially idiosyncratic discretion" is. ${ }^{8}$ In Part II, I explain in greater detail what makes incentives collateral and suggest that systematic incentives to exercise discretion in certain ways present a problem greater than idiosyncratic influences, arising from the inevitable variability in police officers' preferences.

Why are collateral incentives to arrest objectionable? One might well think that the public interest is served by a more effective enforcement of the immigration laws and the identification of criminals who perpetrated unsolved crimes. DHS officials emphasize that the program enables a more efficient detection of deportable non-citizens, but "does not in any way change local jurisdiction's existing law

8. Stephanos Bibas, Bulk Misdemeanor Justice, 85 S. CAL. L. REV. PostsCRIPT 73, 75 (2013), http://lawreview.usc.edu/wp-content/uploads/slideshow/Bibas-PS-Final-PDF.pdf. 
enforcement or fingerprinting policies, procedures, or practices." ${ }^{\text {T }}$ The assumption behind Secure Communities is "that LEAs continue to enforce the criminal law in exactly the same manner as they did before Secure Communities was activated." 10 The King majority similarly maintains that the benefits of DNA matching are obtained without changing law enforcement practices because "DNA collection is not subject to the judgment of officers whose perspective might be 'colored by their primary involvement in the often competitive enterprise of ferreting out crime." "11 In short, the discourse surrounding these policy innovations tends to present arrests as useful tools that can be put to various social purposes at no additional cost. ${ }^{12}$ An obvious fact is elided in this exposition: the decision to arrest may be influenced by the officer's awareness of the screening regimes and his assessment of the likelihood that the offender he is confronting is a dangerous recidivist or an immigration violator.

Even if police were influenced by collateral incentives, what of it? The decision to arrest is, after all, discretionary. Police have no general duty to arrest and may lawfully arrest anyone for just about any reason once probable cause is present. ${ }^{13}$ This article offers two interrelated reasons to resist the proliferation of collateral incentives. The first reason, explored in Part III, is normative, based on a familiar principle that originated at common law but has survived into the modern era as the dominant standard to guide the discretionary decisions to arrest. That principle - the "prosecution principle"-holds that police decisions to arrest ought to be guided by the interest in prosecution for the crime of arrest. Collateral incentives, by definition, steer police away from that purpose. Of course, police routinely arrest for a variety of reasons, and

9. See ICE Office of the Director, Protecting the Homeland: ICE Response to the Task Force on Secure Communities Findings and Recommendations, DeP'T OF HOMELAND SEC. 11 (Apr. 27, 2012), http://www.dhs.gov/xlibrary/assets/hsac/ice-response-to-task-force-on-secure-communities .pdf [hereinafter DEP'T OF Homeland SEC.]; Frequently Asked Questions (FAQs): What are the benefits of Secured Communities?, IMMigRATION AND CUSTOMS ENFORCEMENT, http://www.ice .gov/secure_communities/faq.htm (last visited Apr. 22, 2015).

10. DEP'T OF HOMELAND SEC., supra note 9, at 10-11.

11. Maryland v. King, 133 S. Ct. 1958, 1970 (2013) (quoting Terry v. Ohio, 392 U.S. 1, 12 (1968)).

12. See Ken Wallentine, Collection of DNA Upon Arrest: Expanding Investigative Frontiers, THE POLICE CHIEF (Jan. 2010), http://www.policechiefmagazine.org/magazine/index.cfm ?fuseaction=display_arch\&article_id=1982\&issue_id=12010 ("DNA collection upon arrest will save lives, prevent violent crime by recidivists, save costly investigative resources, improve identification procedures, reduce misidentification, reduce convictions based on false confessions, and clear numerous cold cases.").

13. See infra Part III.C.2. 
the prosecution principle does not demand legal sanctions to root out every other motive underlying arrests. Nonetheless, systematic incentives to arrest for collateral benefits are in tension with the principled legal foundations of the arrest power - in particular, when they are created by means other than explicit state legislative expansion of that power.

The second reason to resist the proliferation of collateral incentives, addressed in Part IV, is practical. Collateral incentives are liable to affect arrest patterns in ways that differ from the effects of many other dubious influences. Collateral incentives should be expected to have one or both of two effects: a redistributive effect on the pool of arrestees, including along ethno-racial lines, and an adverse effect on arrest quality. Critics of marrying immigration enforcement to local policing consistently allege that it leads to targeting of Hispanics. ${ }^{14}$ And courts and scholars express a similar concern about the impact of DNA collection. $^{15}$ For a subset of arrests, as I demonstrate, collateral incentives are likely to result in both greater unwarranted inequality in arrest patterns and lower quality arrests. Moreover, although the literature tends to worry most about undue influences on discretion with regard to high-discretion petty crimes, I offer reasons why we should also expect consequences with regard to serious crimes.

\section{Defining Collateral InCENTIVES}

The power to arrest is one of the most fundamental forms of the state's power to coerce. As recent controversies surrounding the police

14. E.g., Aarti Kohli et al., Secure Communities by the Numbers: An Analysis of Demographics and Due Process, Chief Justice EARL WARREn InSt. On LaW \& Soc. POL'Y (Oct. 2011), https:// www.law.berkeley.edu/files/Secure_Communities_by_the_Numbers.pdf; Secure Communities ("SComm"), ACLU (Sept. 28, 2012), https://www.aclu.org/immigrants-rights/immigration-enforce ment/secure-communities-s-comm.

15. United States v. Pool, 621 F.3d 1213, 1232 (9th Cir. 2010) (Lucero, J., concurring) (noting "a substantial danger that law enforcement personnel will use the DNA-testing regime as a pretext for obtaining evidence against individual suspects"), vacated, 659 F.3d 761 (9th Cir. 2011); People v. Buza, 129 Cal. Rptr. 3d 753, 780 (Cal. Ct. App. 2011) (cautioning that DNA collection "might provide an incentive to pretextually arrest a person from whom the police desire a DNA sample"), withdrawn, 262 P.3d 854 (Cal. 2011), and vacated, 302 P.3d 1051 (Cal. 2013); Lapp \& Radice, supra note 6, at 175 (warning that "DNA collection triggered by any arrest quickly leads to a DNA database of men of color.”); Wayne A. Logan, Policing Identity, 92 B.U. L. REV. 1561, 1586, 1589 (2012) (warning that "[w]ith no limit on the pre-conviction collection of identity evidence, police will . . . be free to exponentially populate DNA databases."); see also Simon A. Cole, Fingerprint Identification and the Criminal Justice System: Historical Lessons for the DNA Debate, in DNA AND THE CRIMINAl Justice System: The TeChNOlogy of Justice $63-89$ (David Lazer ed., 2004). 
use of force in Ferguson, Missouri, and Staten Island, New York, remind us, this power to deprive individuals of their liberty is accompanied by the power to use force, including lethal force. ${ }^{16}$ The decision to exercise the power to arrest ${ }^{17}$ rests, to a large extent, within the discretion of the officer. ${ }^{18}$ Discretion in this realm means, among other things, that police may choose to arrest for relatively petty violations or select whom to arrest for arbitrary, unjustifiable reasons. The Supreme Court and lower courts have long recognized this discretion, and the concomitant potential for its misuse, ${ }^{19}$ which is often explicitly tolerated. For instance, in her dissent in Atwater v. City of Lago Vista, the case upholding police authority to make custodial warrantless arrests for fineonly misdemeanors, Justice O'Connor underscored the "grave potential for abuse" 20 created by the power to arrest anyone for common, petty violations. The majority did not deny that abuses are possible, but explained that the appropriateness of a constitutional remedy depended, as Justice Souter put it, on "how bad the problem is out there." 21 So long as the abuses of discretion to arrest are kept within some acceptable levels, the Atwater majority intimated, these must be tolerated as unavoidable incidents of discretion.

In Atwater, as in other cases, the Court pointed to constraints, legal and institutional, which function to contain the magnitude of "the problem" and channel police discretion towards legitimate purposes. ${ }^{22}$ The key constraints on the abuse of discretion as well as unlawful arrests stem from the Fourth Amendment's probable cause requirement itself. ${ }^{23}$

16. See, e.g., Yoni Bashan, Comparing the Michael Brown and Eric Garner Cases, WALL ST. J. (Nov. 25, 2014, 9:33 PM), http://www.wsj.com/articles/comparing-the-michael-brown-and-ericgarner-cases-1416969202. For an overview of the constitutionally permissible use of force in effecting an arrest, see 3 Wayne R. LaFave, Search \& Seizure: A Treatise on the Fourth AMENDMENT § 5.1(d) (5th ed. 2013).

17. By arrests in this context, I mean "custodial arrests," rather than a brief detention at the scene promptly followed by release. See LAFAVE, supra note 16, at $\S 5.1$ (a) ("In United States $v$. Robinson, the Court came up with the seemingly redundant phrase 'custodial arrest' to distinguish those arrests followed by release at the scene," whether the latter are technically characterized as arrests or temporary seizures).

18. See, e.g., Foley v. Connelie, 435 U.S. 291, 298 (1978) ("the exercise of police authority [with regard to arrests, inter alia] calls for a very high degree of judgment and discretion").

19. Id. ("the abuse or misuse of [discretionary authority] can have serious impact on individuals.").

20. Atwater v. City of Lago Vista, 532 U.S. 318, 372 (2001) (O’Connor, J., dissenting).

21. Transcript of Oral Argument at 20, Atwater v. City of Lago Vista, 532 U.S. 318 (2001) (No. 99-1408).

22. Atwater, 532 U.S. at 353.

23. Id. at 352 ("So far as [warrantless misdemeanor] arrests might be thought to pose a threat to the probable-cause requirement, anyone arrested for a crime ... is entitled to a magistrate's review 
Other constraints, which courts invoke when they decline to impose discretion-limiting rules on police, derive from other sources: the Supreme Court has pointed to the Equal Protection Clause as a safeguard against discriminatory enforcement; ${ }^{24}$ Justice Souter invoked "good sense" that the police themselves possess that it is in their own "interest... to limit petty-offense arrests, which carry costs that are simply too great to incur without good reason," as well as "the political accountability. . . of most local lawmakers and law-enforcement officials. $" 25$ Other courts have noted the prosecutorial screening function $^{26}$ and civil suits. ${ }^{27}$ In I.N.S. v. Lopez-Mendoza, where the Court declined to apply the Fourth Amendment exclusionary rule to deportation proceedings, it did so in part in reliance on mechanisms of internal discipline: the INS "ha[d] its own comprehensive scheme for deterring Fourth Amendment violations." 28 The expectation is that, by and large, these constraints are sufficient to deter unlawful arrests, and to generally incentivize police to make arrests for the "right" reasons and on proper grounds. Should these safeguards fail, however, some Supreme Court Justices expressed the inclination to reconsider decisions such as Atwater: as Justice Ginsburg noted, joined by three others,

of probable cause within 48 hours.").

24. E.g., Whren v. United States, 517 U.S. 806, 813 (1996) ("[t]he constitutional basis for objecting to intentionally discriminatory application of laws is the Equal Protection Clause ...."); Holland v. City of Portland, 102 F.3d 6, 11 (1st Cir. 1996) ("[An] equal protection challenge to an arrest, despite probable cause existing, might yet be entertained ...." (citation omitted)); United States v. Scopo, 19 F.3d 777, 786 (2d Cir. 1994) (Newman, J., concurring) ("[T]he Equal Protection Clause has sufficient vitality to curb most of the abuses" that are unsanctioned by the Fourth Amendment).

25. Atwater, 532 U.S. at 352-53; see also State v. Lopez, 873 P.2d 1127, 1135 (Utah 1994) ("Admittedly, police officers must decide which one of many traffic offenders to stop. However, this decision is, for the most part, channeled by the desire of the police to apprehend the most serious offenders.").

26. E.g., United States v. Causey, 834 F.2d 1179, 1181 (5th Cir. 1987) (explaining that bad intent on the part of the police is irrelevant, because "[i]t is the prosecutor's intent that determines whether one who has been arrested on a warrant is prosecuted for that offense, not that of the police"); Smiddy v. Varney, 803 F.2d 1469, 1472 (9th Cir. 1986) (noting that "[t]he possibility of less than perfect investigative conduct on the part of the police" will be checked by the "prosecutor [who] has a duty to measure the facts in the report by legal standards and decide whether they add up to probable cause to prosecute").

27. Scopo, 19 F.3d at 786 (Newman, J., concurring) ("[o]fficers who misuse the authority we approve today may expect to be defendants in civil suits seeking substantial damages for discriminatory enforcement of the law.").

28. I.N.S. v. Lopez-Mendoza, 468 U.S. 1032, 1044-45 (1984); see also Eric J. Miller, Detective Fiction: Race, Authority, and the Fourth Amendment, 44 ARIZ. ST. L.J. 213, 222-23 (2012) (discussing the Supreme Court's faith in mechanisms of police self-regulation and professionalism in cases withdrawing the exclusionary rule for certain violations). 
should "experience demonstrate[] 'anything like an epidemic of unnecessary minor-offense arrests,' I hope the Court will reconsider its recent precedent." ${ }^{29}$ This Part elaborates the character of collateral incentives, and demonstrates that these safeguards should be expected to fail more often when police act on such incentives than if they act on other ulterior motives frequently discussed by scholars and courts.

\section{A. The Arrest Calculus}

To appreciate the effects of collateral incentives on police exercise of discretion, it is useful to formalize a stylized cost-benefit arrest calculus. Police care about the number of arrests they make, a common measure of productivity. ${ }^{30}$ And police care about enforcement costs, including effort. Beyond that, it is not easy to figure out what exactly the police are "maximizing" in making arrests. ${ }^{31}$ What can be said at a high level of generality is that officers seek to maximize "arrest value." That is, they seek to make the arrests of highest value to them at least cost. What makes an arrest "valuable" to a particular officer is not wholly predictable, and as a result, there is little we can say about an optimal set of arrests for each officer. ${ }^{32}$ There is, however, something we can say

29. Arkansas v. Sullivan, 532 U.S. 769, 773 (2001) (Ginsburg, J., concurring); see also LopezMendoza, 468 U.S. at 1050 (declining to apply the exclusionary rule to removal proceedings, but noting that the Court's "conclusions concerning the exclusionary rule's value might change, if there developed good reason to believe that Fourth Amendment violations by INS officers were widespread.").

30. There is ample evidence that arrests are treated as one measure of productivity by LEAs. See e.g., Floyd v. City of New York, 959 F. Supp. 2d 540, 595-97 (S.D.N.Y. 2013), appeal dismissed (Sept. 25, 2013) (presenting evidence that police felt pressure to "increase arrests" based on a 2008 survey of NYPD retirees, and reviewing other evidence of supervisors directing officers to meet numerical enforcement goals "backed by the threat of negative consequences"); Justin Fenton, Baltimore Officer Pleads Guilty to Armed Drug Conspiracy, BALT. Sun (Mar. 11, 2013, 8:42 PM), http://www.baltimoresun.com/news/maryland/crime/blog/bs-md-ci-police-officer-plea-richburg20130311,0,6845283.story\#ixzz2amOISgV3 (explaining that the illegal actions of a Baltimore police officer were driven by the need "[t]o rack up arrests and look good for his bosses"); Justin Peters, Do Arrest Quotas Encourage Police Officers to Break the Law?, SLATE (Mar. 15, 2013, 9:00 AM), http://www.slate.com/blogs/crime/2013/03/15/kendell_richburg_baltimore_police_do_arrest_ quotas_encourage_cops_to_break.html (reviewing several public scandals surrounding alleged arrest quotas).

31. Daniel Richman makes this point with regard to prosecutors: "I can only throw up my hands and beg the reader's indulgence for my failure to figure out precisely what prosecutors or agents seek to maximize. Convictions? Sentence-years? Deterrence? Agency prestige? Lifetime earnings? Leisure? My provisional assumption is that every prosecutor . . . is impelled by a broad variety of motives ...." Prosecutors and Their Agents, Agents and Their Prosecutors, 103 CoLUM. L. REV. 749, 758 (2003).

32. Even within a single unit, what makes arrests valuable likely differs among individual officers. See, e.g., Peter Moskos, COP In THE HoOd: My YeAr POLICING Baltimore’s EAstern 
about arrest decisions for any one offense or a class of comparable offenses.

The value police derive from making an arrest can be disaggregated into two components, the "intrinsic" and the "extrinsic." I posit here that the "intrinsic" value of the arrest hinges on the possibility of prosecution of the arrestee on the basis of conduct that prompted the arrest. Part III defends this proposition at greater length; for the time being, it is just a presumption about the core interests served by arrests. In this regard, police may derive some benefit from the fact of making a lawful arrest. They may derive a further benefit from a fruitful arrest, or an arrest that in fact leads to prosecution and a possible conviction. The expected intrinsic value of any arrest is the sum of the benefit of a lawful arrest, discounted by the probability that probable cause is lacking, and the benefit of a fruitful arrest, discounted by the probability of nonprosecution. ${ }^{33}$ It is reasonable to assume that the intrinsic benefits of arrest are the same across suspects for the same offense or class of violations. $^{34}$ The quality of the arrest is a function of its evidentiary basis, and dismissal by the magistrate or non-prosecution are qualitybased constraints on police arrest decisions. ${ }^{35}$ Insofar as police care

DISTRICT 136-45 (2008) (describing heterogeneity in arrest behaviors among officers, describing some officers in a squad as "high-arrest officers" and others as "low-arrest officers," and reporting that some officers intentionally make no arrests for a particular set of offenses).

33. There is evidence that police care about prosecution to some extent, and are thus responsive to prosecutorial screening. See, e.g., George F. Cole, The Decision to Prosecute, in Rough Justice: PERSPECTIVES ON LOWER CRIMINAL COURTS 127 (John A. Robertson ed., 1974) (noting that "rejection of too many cases can have serious repercussions affecting the morale, discipline, and workload of the force"); Joseph Goldstein, Prosecutor Deals Blow to Stop-and-Frisk Tactic, N.Y. TIMES (Sept. 25, 2012), http://www.nytimes.com/2012/09/26/nyregion/in-the-bronx-resistance-toprosecuting-stop-and-frisk-arrests.html?pagewanted=all (reporting on the Bronx District Attorney's new policy to interview every officer making trespass arrests, and declining to automatically prosecute, with the result that trespass arrests had fallen by a third). Police departments' internal rules may also impose costs on police officers if the D.A. rejects the charges sought by the officer, for example, Houston Police Dep't General Order 500-7 (requiring the officer to give details and explain D.A.'s reasons for rejecting officer's attempt to file charges, and providing for supervisory review when "the charges are rejected because of alleged mishandling by an officer").

34. As noted, little can be said about the relative intrinsic value of arrests across different offenses or offense types.

35. Low quality of arrests is a major reason for non-prosecution. See Peter GreEnwood ET al., Prosecution of Adult Felony Defendants in los Angeles County: A Policy PERSPECTIVE 66-68 (1973) (finding that insufficiency of evidence is a leading reason for rejection of felony charges); Michael Edmund O'Neill, Understanding Federal Prosecutorial Declinations: An Empirical Analysis of Predictive Factors, 41 AM. CRIM. L. REV. 1439, 1459 tbl.10 (2004) (finding that in $22 \%$ of cases, prosecutors give the weakness of evidence as the reason, and in another $8 \%$ that no crime was committed); see also Rachel A. Harmon, The Problem of Policing, 110 MICH. L. REV. 761, 805 (2012) ("If an officer accumulates accusations of dishonesty or bias that would have to be disclosed, prosecutors will sometimes pressure his police chief to reassign him 
about the lawfulness and the fruitfulness of an arrest, they will seek to make higher quality arrests.

Police may also derive some extrinsic benefit from making an arrest, which is anything perceived as a benefit beyond that of a lawful or fruitful arrest. Such a benefit may arise from external incentives, such as a rule that pays a premium to officers for every arrest. It may also arise purely from internal motives, such as the satisfaction an officer might feel from arresting a personal enemy. The expected extrinsic value of any given arrest is the probability that its extrinsic benefit materializes, discounted by the probability that the officer suffers some sanction for the arrest, such as a civil suit or a disciplinary action related to the unlawful arrest.

The total expected value of an arrest is the sum of its intrinsic and extrinsic components, further discounted by the probability that the arrest will lead to some legal challenge, such as on the basis of equal protection or state racial profiling laws. ${ }^{36}$ One may justifiably conclude that civil suits for constitutional violations, whether on the basis of unlawful arrests or on equal protection grounds, are infrequent, ${ }^{37}$ while constraints internal to the criminal justice system-i.e., no-probable cause determinations, non-prosecutions, and departmental discipline - are more common, and are thus more energetic constraints on police activity. ${ }^{38}$

rather than have him work cases in which he could become a key trial witness ... [C]hiefs often comply and move the officer to a less appealing administrative assignment.").

36. Because sanctions based on these bases may apply even to lawful (legally sufficient) and fruitful arrests, as well as legally insufficient arrests, it is the total value derived from an arrest that is diminished by this prospect.

37. The Equal Protection Clause (EPC) does not constrain as much as it might, due to the high burden of proof on the plaintiff. See United States v. Armstrong, 517 U.S. 456, 465 (1996) ("The claimant must demonstrate that the ... policy 'had a discriminatory effect and that it was motivated by a discriminatory purpose."' (citation omitted)). Claims that the EPC places no meaningful limits on criminal enforcement discretion have long been commonplace. See, e.g., Daniel J. Givelber, The Application of Equal Protection Principles to Selective Enforcement of the Criminal Law, 1973 U. ILL. L. FORUM 88, 90 (1973) ("[J]udicial application of the equal protection clause in this area is grudging. Present doctrine affords neither relief to those claiming to be the victims of abusive selective enforcement nor control over selective enforcement decisions."); David A. Harris, "Driving While Black" and All Other Traffic Offenses: The Supreme Court and Pretextual Traffic Stops, 87 J. CRIM. L. \& CRIMINOLOGY 544, 551-52 (1997) (explaining why equal protection offers little redress for unequal policing). Claims that civil suits for unlawful searches and seizures are ineffective are likewise common. See, e.g., David J.R. Frakt, Fruitless Poisonous Trees in A Parallel Universe: Hudson v. Michigan, Knock-and-Announce, and the Exclusionary Rule, 34 FLA. ST. U. L. REV. 659, 691-96 (2007).

38. For evidence that internal discipline, based in particular on Early Intervention Systems (EIS), affects officers' conduct, see SAMUEL S. WALKER ET AL., U.S. DEP'T OF JUSTICE, EARLY WARning Systems: Responding to THE Problem POLICE OfFicer (2001), available at https:/www.ncjrs.gov/pdffiles1/nij/188565.pdf. On the importance of departmental discretion 
Thus, I focus the discussion on the constraints that are internal to the criminal justice system, rather than the (lesser) possibility of legal challenges.

Plainly, police officers make decisions to arrest for many extrinsic benefits unconnected with the prospects of actually prosecuting the arrestee for the crime of arrest. Not all of these reasons are equally problematic. The extrinsic benefit of an arrest may or may not be (i) correlated with $^{39}$ or (ii) legally and institutionally dependent on the quality of arrest. Collateral incentives to arrest exist when the realization of extrinsic benefits is both uncorrelated with and legally and institutionally independent of the quality of arrests. To say that a benefit is legally independent means that no rule of law deprives the police of the benefit if an arrest is unlawful. Institutional independence, in turn, refers to the independence of the benefit from internal disciplinary sanctions for unlawful or fruitless arrests. The likelihood of a disciplinary sanction depends on, among other things, whether the LEA shares the extrinsic benefit influencing officers to make arrests. In this light, external incentives may be contrasted with subjective, idiosyncratic motives: as a general matter, officers acting on incentives created by rules or institutions applicable to all should be disciplined less often than officers acting on idiosyncratic motives. By contrast, some extrinsic benefits may be described as merely "ulterior," rather than wholly collateral, because to reap those benefits police must still be attentive to arrest quality due to correlation of the benefit with guilt, or legal or institutional dependence.

\section{B. Immigration and DNA Screening as Collateral Incentives}

As suggested, the immigration and DNA screening regimes create extrinsic benefits, which affect law enforcers' arrest incentives. Secure Communities is not the first innovation that automates detection of immigration violators or links federal law enforcement to local criminal law enforcement, and the concerns about collateral incentives raised here apply to some extent to certain earlier programs, as well as some

generally, see Nirej S. Sekhon, Redistributive Policing, 101 J. CRIM. L. \& CRIMINOLOGY 1171 (2011); Jeffrey S. Nowacki, Organizational-Level Police Discretion: An Application for Police Use of Lethal Force, CRime AND DelinQuency, Nov. 2011; Barbara E. Armacost, Organizational Culture and Police Misconduct, 72 GEO. WASH. L. REV. 453 (2004).

39. To be more precise, correlation in this context is between signals of guilt of the crime of arrest and signals that the extrinsic benefit is likely to materialize. 
initiatives by localities to obtain immigration information from DHS. ${ }^{40}$ But, the Secure Communities program is the last and most comprehensive step in the federal government's automation of immigration screening. The DHS operates IDENT, a database which contains biometric data on a variety of known and potential immigration violators. ${ }^{41}$ Fingerprints taken by law enforcement agencies are routinely transmitted to the FBI for a criminal background check. ${ }^{42}$ Between 2008 and 2013, Secure Communities linked IDENT to FBI's IAFIS in every U.S. county, allowing these fingerprints to be checked against IDENT as well. A fingerprint match leads immigration officials to investigate further. $^{43}$ If immigration officials decide to initiate deportation proceedings against the arrestee, historically, a detainer is issued to the LEA requesting that the suspect be detained for up to 48 hours for the U.S. Immigration and Customs Enforcement (ICE) to assume custody. ${ }^{44}$ Local law enforcers may perceive the program to deliver a benefit in one of two ways: screening may identify individuals who will in fact be placed in deportation proceedings by ICE, thereby removing immigration violators from the jurisdiction irrespective of charges against them; and, in the case of individuals who otherwise would be charged, held, and

40. For an overview of evolving use of immigration databases, see Anil Kalhan, Immigration Policing and Federalism Through the Lens of Technology, Surveillance, and Privacy, 74 OHIO ST. L.J. 1105, 1131-34 (2013); for an overview of local initiatives to detect immigration violators, see Monica W. Varsanyi et al., A Multilayered Jurisdictional Patchwork: Immigration Federalism in the United States, 34 L. \& POL'Y 146 (2011).

41. Dep't of Homeland Sec., Office of the Inspector General, Communication Regarding Participation in Secure Communities, OIG-12-66 (Revised), 3 nn.2-3 (June 23, 2014), http://www.oig.dhs.gov/assets/Mgmt/2012/OIG_12-66_Jun14.pdf. For a more detailed explanation of how records are entered into the database, see Privacy Impact Assessment for the Automated Biometric Identification System (IDENT), DEP'T OF HOMELAND SEC. 11-15 (Dec. 7, 2012), http://www.dhs.gov/sites/default/files/publications/privacy/PIAs/privacy_pia_usvisit_ident_appendi xj_jan2013.pdf.

42. FBI's IAFIS (Integrated Automated Fingerprint Identification System) database has been operational since 1999. Integrated Automated Fingerprint Identification System, FBI, http://www. fbi.gov/about-us/cjis/fingerprints_biometrics/iafis/iafis (last visited Apr. 22, 2015).

43. Officers of the Law Enforcement Support Center (LESC) further investigate the individual's immigration status; LESC's response is then forwarded to the relevant ICE field office, and routed back to the arresting LEA. See DeP'T OF Homeland SEC., Secure Communities, http://www.ice.gov/secure_communities/ (last visited Apr. 22, 2015).

44. A detainer is a request by immigration officers to hold the individual. See Kevin R. JOHNSON ET AL., UNDERSTANDING IMMIGRATION LAW 84 (2009). As part of recent policy changes, DHS Secretary Jeh Johnson directed ICE to replace detainers "with requests for notification (i.e., requests that state or local law enforcement notify ICE of a pending release during the time that person is otherwise in custody under state or local authority)." Jeh Johnson, Secure Communities, 1, 2 (2014) [hereinafter Johnson Memo], http://www.dhs.gov/sites/default/files/publications/14_1120_ memo_secure_communities.pdf. 
possibly incarcerated by the local authorities, the prospect of deportation potentially saves local law enforcement resources. Although in connection with President Obama's executive action on immigration in late 2014, DHS announced that Secure Communities is to be "discontinued," the transmission of fingerprints, screening, and the potential for deportation of some immigration violators remain in place. ${ }^{45}$

The centerpiece of the DNA screening regimes is CODIS, which contains over 10 million DNA profiles, collected by local, state and federal law enforcement officials during criminal investigations (the forensic profiles) and from individuals arrested for or convicted of crimes. $^{46}$ The federal government and 30 states have enacted laws providing for involuntary DNA collection from individuals arrested for some crimes, requiring no warrant or additional justification. ${ }^{47}$ After a digital profile of the arrestee's DNA sample is created, it is added to the DNA database and analyzed for matches to existing profiles. In fifteen states, DNA collection is limited to serious felonies; in nine states, collection encompasses all felonies; and in eight states, it extends also to certain misdemeanors. ${ }^{48}$ Calls for expanding coverage to more crimes are common. ${ }^{49}$

The following sections illustrate that the realization of benefits promised by the immigration and some, if not all, DNA screening regimes are largely uncorrelated with and independent of the quality of arrests, and demonstrate how collateral incentives differ from some

45. Johnson Memo, supra note 44, at 1. By directing ICE to "discontinue" Secure Communities, Secretary Johnson meant that ICE should not seek deportation of every non-citizen identified, but to follow existing enforcement priorities, which focus on individuals with prior criminal convictions. See also DEP'T OF Homeland SEC., FY 2014 ICE Immigration Removals: Patterns \& Demographics, n.1 http://www.ice.gov/removal-statistics\#ft2 (last visited Apr. 25, 2015). If the changes are implemented, this means that local police cannot expect that every deportable noncitizen would in fact be deported, but that expectation remains reasonable for a considerable subset.

46. In the federal database, 1,922,415 samples were arrestee DNA profiles and 565,159 were forensic profiles as of July 2014. See CODIS-NDIS Statistics, FBI, http://www.fbi.gov/aboutus/lab/biometric-analysis/codis/ndis-statistics (last visited Apr. 22, 2015).

47. See Nat'l Conference of State Legislatures, DNA Arrestee Laws (2013), http://www.ncsl.org/Documents/cj/ArresteeDNALaws.pdf [hereinafter NCSL].

48. See id.; Julie Samuels et al., Collecting DNA From Arrestees: Implementation Lessons, 270 NAT'L INST. JUST. J. 18, 20 (2012), https://www.ncjrs.gov/pdffiles1/nij/238484.pdf.

49. See, e.g., House Research Org., Texas House of Representatives, Should Texas Expand Its DNA Arrestee Database?, Focus REPORT, Mar. 24, 2014, http://www.hro.house.state.tx.us/pdf/ focus/DNA83-8.pdf (discussing proposed bills in Texas to broaden DNA collection on arrest for misdemeanors); Jaime Adame, Will Okla. Authorities Collect DNA from the Accused?, OKLA. WATCH (Dec. 21, 2013), http://oklahomawatch.org/2013/12/21/will-okla-authorities-collect-dnafrom-the-accused/ (discussing proposed bill in Oklahoma to broaden DNA collection on arrest for all felonies and some misdemeanors). 
merely ulterior considerations that influence the exercise of arrest discretion.

\section{Non-correlation}

Consider the familiar notion of "statistical discrimination," which entails using group traits as one basis for selecting targets for enforcement on account of perceived disparities in offending between identifiable groups. ${ }^{50}$ The practice is a particularly controversial one when the groups are ethno-racially defined, but the relevant group trait need not be ethnicity or race: age and gender, for instance, are major predictors of criminal offending, and police routinely focus on young males for this reason. ${ }^{51}$ Statistical discrimination would lead an officer to focus on a person suspected of crime A because he is a member of the group thought to have higher offense rates for that same crime A. ${ }^{52}$ One may justifiably harbor a number of serious misgivings about statistical discrimination; however, if statistical discrimination is based on an accurate assessment of differential offending, it leads police to focus on suspects statistically more likely to be guilty of the crime of arrest.

\section{a. Immigration Screening}

Now compare statistical discrimination to profiling on the basis of the extrinsic benefit created by on-arrest immigration screening-the

50. See, e.g., John Knowles et al., Racial Bias in Motor Vehicle Searches: Theory and Evidence, 109 J. POL. ECON. 203, 205 (2001).

51. Objections to statistical discrimination are many: profiling on any group traits is controversial, inter alia, because it is in tension with individualized suspicion, and profiling on the basis of race burdens innocent members of the profiled group disproportionately. See, e.g., Albert W. Altschuler, Racial Profiling and the Constitution, 2002 U. CHI. LEGAL F. 163, 167 (2002); David Cole, Discretion and Discrimination Reconsidered: A Response to the New Criminal Justice Scholarship, 87 GEO. L.J. 1059, 1082-83 (1999); Bernard E. Harcourt, Henry Louis Gates and Racial Profiling: What's the Problem? 8 (John M. Olin Law \& Economics, Working Paper No. 4822009, 2009), available at http://papers.ssrn.com/sol3/papers.cfm?abstract_id=1474809. For the present purposes, I imply nothing about the justifiability of the practice, but employ it solely as a contrast to the operation of collateral incentives.

52. For a formal treatment of disparities in arrest rates due to differential perceived rates of offending, see Aleksandar Tomic \& Jahn K. Hakes, Case Dismissed: Police Discretion and Racial Differences in Dismissals of Felony Charges, AM. L. \& ECON. REV. 110 (2008); see also Harcourt, supra note 51, at 17-18 (explaining that selecting on differential offense propensity should lead to the overrepresentation of the higher-offending group in the arrestee population relative to the group's offending rate, and that this overrepresentation becomes worse overtime if police "then rel[y] on the evidence of the resulting correctional traces - arrests, convictions, supervisions - in order to reallocate future law enforcement resources"). 
identification of a deportable person and a high chance of their deportation. Insofar as we have good empirical evidence, the probability of an individual's deportability is generally uncorrelated with arrest quality. The emerging scholarly consensus is that immigrants, whether authorized or not, are less prone to crime than natives. ${ }^{53}$ That generalization does not apply across the board: notably, it is not the case for criminal violations of immigration laws themselves, or a few offenses to which the undocumented are peculiarly susceptible, such as document fraud or unlicensed operation of a motor vehicle when eligibility for drivers' licenses is restricted. However, for the vast majority of crimes, immigrant status as the signal of deportability is uncorrelated with the signal of criminality, and most crimes of arrest for the undocumented will be for crimes that are unrelated to criminal immigration law violations. $^{54}$

Sometimes police can identify a suspect as foreign-born, a reasonable indicator for non-citizens. Often police cannot directly

53. See Ramiro Martinez, Jr. \& Matthew T. Lee, On Immigration and Crime, in 1 CRIMINAL Justice 2000-The NATURe OF CRime: Continuity AND ChANGE, 485, 496 (Gary LaFree et al. eds., 2000), http://permanent.access.gpo.gov/lps5244/Vol.\%201/02j.pdf ("[Th]e major finding of a century of research on immigration and crime is that... immigrants nearly always exhibit lower crime rates than native groups."); Rubén G. Rumbaut, Undocumented Immigration and Rates of Crime and Imprisonment: Popular Myths and Empirical Realities, IDEAS IN AM. Policing, April 2009, at 126 (finding that "the lowest incarceration rates among Latin American immigrants are seen for the least educated groups, who are also the groups who account for the majority of the undocumented: the Salvadorans[,] Guatemalans [], and the Mexicans"); Robert J. Sampson, Op-Ed., Open Doors Don't Invite Criminals, N.Y. TIMES (Mar. 11, 2006), http://www.nytimes. com/2006/03/11/opinion/11sampson.html (describing results of his study that revealed that Latin American immigrants are less violent and less likely than the second and third generations to commit crimes even when they live in dense communities with high rates of poverty); see also Laura J. Hickman and Marika J. Suttorp, Are Deportable Aliens A Unique Threat to Public Safety? Comparing the Recidivism of Deportable and Nondeportable Aliens, 7 CRIMINOLOGY \& PUB. POL'Y 59 (2008). A growing body of social-science literature also indicates that higher concentrations of immigrants do not correlate with higher crime rates. See, e.g., John M. MacDonald et al., The Effects of Immigrant Concentration on Changes in Neighborhood Crime Rates, 29 J. QUANTITATIVE CRIMINOLOGY 191 (2013); Jacob I. Stowell et al., Immigration and the Recent Violent Crime Drop in the United States: A Pooled, Cross-Sectional Time-Series Analysis of Metropolitan Areas, 47 CRIMINOLOGY 889 (2009).

54. While DHS did not collect systematic data on crimes of arrest under Secure Communities, it did collect that data for about $44 \%$ of those removed as a result of Secure Communities during fiscal year 2011 and the first half of 2012: 37\% of arrests were for traffic offenses, $12 \%$ were "dangerous drug" offenses, $10 \%$ were various assault offenses, and $40 \%$ were "other" offenses, a category that includes many common crimes such as larceny, burglary, fraud, obstructing the police, weapon offenses, robbery, and smuggling. In sum, a typical arrest that ultimately resulted in a deportation was for a range of crimes, most of which are unrelated to those to which the undocumented are particularly susceptible. U.S. GOV'T ACCOUNTABILITY OFFICE, GAO-12-708, Secure Communities: Criminal Alien Removals Increased, But Technology Planning IMPROVEMENTS NEEDED 22-24 (2012), available at http://www.gao.gov/products/GAO-12-708. 
identify all foreign-born, and the indicator most commonly cited as employed by police seeking deportable immigrants under current demographic conditions is Hispanic or Latino ethnicity. Focusing on Hispanic ethnicity alone is also not likely to be an informative signal of guilt for many crimes in many jurisdictions.

Hispanic involvement in crime has been understudied due to a historic dearth of ethnicity data. ${ }^{55}$ Insofar as ethnicity data has become available, it shows that incarceration rates, and certain arrest rates, for Hispanics have become higher than those of Whites over the past two decades, but lower than those of Blacks. ${ }^{56}$ However, more systematic research suggests that for many crime categories, the inference that Hispanic involvement in crime is higher than that of White nonHispanics is unwarranted. Incarceration statistics overstate Hispanic offending for a combination of reasons: first, as criminologists caution in general, disparities in official statistics "may reflect biases in the way criminal justice institutions treat different racial and ethnic groups rather than differences in actual offending. ${ }^{, 57}$ Beyond that, the growing population of undocumented immigrants leads to an underestimate of the Hispanic population in the numerator, thus overestimating rates, ${ }^{58}$ second, the most crime-prone group-young males-is larger in the Hispanic than non-Hispanic population, which assures higher offense

55. Fewer data sources report Hispanic ethnicity than race. See Jeffrey D. Morenoff, Racial and Ethnic Disparities in Crime and Delinquency in the United States, in ETHNICITY AND CAUSAL MECHANISMS 139-40 (Michael Rutter and Marta Tienda eds., 2005).

56. See, e.g., Jacob I. Stowell et al., Latino Crime and Latinos in the Criminal Justice System: Trends, Policy Implications, and Future Research Initiatives, 4 RACE \& SOC. ProBS. 31, 32 (2012).

57. R. Richard Sampson et al., Social Anatomy of Racial and Ethnic Disparities in Violence, 95 Am. J. Pub. Health 224, 224 (2005); Robert J. Sampson \& J.L. Lauritsen, Racial and Ethnic Disparities in Crime and Criminal Justice in the United States, in ETHNICITY, CRIME, AND Immigration: Comparative and Cross-National Perspectives, Crime and Justice 324 (M. Tonry ed., 1997) ("Findings based on official data such as arrest statistics published by the FBI's Uniform Crime Reports (UCR) are limited to the extent that apprehended offenders differ in some way from nonapprehended offenders (e.g., because of racial bias)."); Morenoff, supra note 55, at 149 (the "major criticism of official records is that they confound differences in the likelihood of arrest and conviction that may result from bias in the criminal justice system"). Importantly, because immigration prosecutions have come to occupy a large share of federal criminal cases, the incarcerated Latino population has increased considerably, giving a not entirely accurate impression that Latinos are more crime prone. See Stowell et al., supra note 56, at 34 (arguing that for these reasons, "it is somewhat premature to conclude that this is suggestive of the fact that Latinos have a higher propensity to engage in criminal violence").

58. See, e.g., Darrell Steffensmeier et al., Reassessing Trends in Black Violent Crime, 1980 2008: Sorting out the "Hispanic effect" in Uniform Crime Reports Arrests, National Crime Victimization Survey Offender Estimates, and U.S. Prisoner Counts, 49 CRIMINOLOGY 197, 208-09 n.5 (2011). 
rates $;{ }^{59}$ and finally, there is evidence that Hispanic defendants are more likely to be sentenced to a term of imprisonment and for longer sentences compared to other groups, which assures Hispanic overrepresentation among the incarcerated. ${ }^{60}$ Studies that draw on sources beyond raw official data almost uniformly find that Hispanic involvement in violent crime is lower than Black involvement, while the comparison to White rates is more complex. Some evidence suggests that Hispanic violence falls "(somewhere) between White and Black levels," ${ }^{\prime}$ and other evidence suggests that Hispanic violence is lower or comparable to White levels. ${ }^{62}$ Hispanic involvement in violent crime, moreover, differs considerably across national origins: there is evidence that Mexican Americans, for instance, exhibit lower rates of violence than White Americans, whereas Puerto Ricans exhibit higher rates. ${ }^{63}$ Because the national origins of the Hispanic population differ considerably across the country, the dominant Hispanic population in many jurisdictions would be no more predisposed towards violent offending than non-Hispanic Whites. With regard to other crime categories, there is evidence that overall illicit drug use among Hispanic youths is not very different from that of Whites, ${ }^{64}$ and for Hispanic immigrants specifically, drug use is

59. Id.

60. E.g., Darrell Steffensmeier \& Stephen Demuth, Ethnicity and Judges' Sentencing Decisions: Hispanic-Black-White Comparisons, 39 CRIMINOLOGY 145, 161 (2001) (finding that in Pennsylvania courts, "White defendants are treated most leniently," and "Hispanic defendants are treated most harshly" with regard to decisions to incarcerate and sentence length, controlling for a host of factors including criminal history and offense levels); Andrew Golub et al., The Race/Ethnicity Disparity in Misdemeanor Marijuana Arrests in New York City, 6 CRIMINOLOGY \& PUB. POL'Y 131, 149 (2007) (finding that in New York City, "Black (10\%) and Hispanic (10\%) [marijuana in public view] arrestees were much more likely to be sentenced to time served [in jail] than White (4\%) MPV arrestees").

61. Steffensmeier et al., supra note 58, at 201 (citing studies).

62. Sampson et al., supra note 57, at 224 (finding that the odds of violence were $85 \%$ higher for Blacks compared to Whites, whereas Latino violence was 10\% lower); Darrell Steffensmeier et al., Scope and Conceptual Issues in Testing the Race-Crime Invariance Thesis: Black, White, and Hispanic Comparisons, 48 CRIMINOLOGY 1133, 1154 (2010) (showing that Hispanic rates of arrest for homicide, aggravated assault, forcible rape, and robbery are nominally higher than for Whites, and concluding that rates are "comparable"). There is evidence that concentrations of Latinos at the aggregate level are associated with lower levels of crime rates for certain crimes. See, e.g., Stowell et al., supra note 53, at 31 (finding that "the concentration of Latinos tends to be associated with lower levels of homicide victimization").

63. Sampson, supra note 57; see also Toya Like-Haislip, Racial and Ethnic Patterns in Criminality and Victimization, in THE OXFORD HANDBOOK OF ETHNICITY, CRIME, AND IMMIGRATION 107, 122 (2013) (reviewing studies).

64. Lloyd D. Johnston et al., Demographic Subgroup Trends for Various Licit and Illicit Drugs, 1975-2009, MONITORING THE FUTURE OCCASIONAL PAPER SERIES 7 (2010), http://www.monitoringthefuture.org/pubs/occpapers/occ73.pdf. 
lower than for other demographic groups. ${ }^{65}$ Less is known about ethnicity disparities for less serious offending, but there is no good evidence to support a general conclusion that Hispanics are more likely to offend than all other ethnic groups. In sum, for many crimes, arrests influenced by the prospective arrestees' likely deportability will lead police to focus on suspects who are not more likely to be guilty of the crime of arrest compared to members of other demographic groups.

\section{b. DNA Collection}

Whether the interest in obtaining a DNA sample leads police to focus on suspects based on features that do not correlate with guilt of the crime of arrest is a more complex question. The interests commonly said to be served by DNA collection go beyond the interest in identification of the individual and his criminal history emphasized by the Supreme Court in Maryland v. King. ${ }^{66}$ DNA collection and analysis also provides the extrinsic benefit of solving unsolved crimes by means of matches ("cold hits") between the arrestee's DNA profile and that collected at an unsolved crime scene. ${ }^{67}$ Importantly, DNA collection also serves simply to insert DNA profiles into the database, so as to deter and detect any further crimes by the DNA donor. ${ }^{68}$

65. Charles M. Katz et al., Assessing the Relationship Between Immigration Status and Drug Use, 28 JusT. Q. 541, 560 (2010) (finding that (Hispanic) illegal immigrants in Maricopa County, Arizona, were "significantly less likely to use marijuana, methamphetamine, or any illicit drug when compared to US citizens"); Enrico A. Marcelli, An Estimate of the Level and Determinants of Illicit Drug Use Among Unauthorized Latino Immigrant Arrestees in California, 31 J. DRUG IssuES 487, 503 (2001) (finding that unauthorized Latino immigrant arrestees in California were less likely to use drugs than citizens).

66. Maryland v. King, 133 S. Ct. 1958, 1971 (2013).

67. A "cold hit" in the DNA database is a more likely event than a fingerprint match to prints lifted from a crime scene. See Haskell v. Harris, 669 F.3d 1049, 1064 (9th Cir. 2012). Studies suggest that adding arrestee profiles to CODIS likely increases the number of "hits" and aids more investigations, although the true effect of additional arrestee profiles is obscured by the fact that many such profiles would have been added after conviction. See Julie E. Samuels et al., Collecting DNA at Arrest: Policies, Practices, and Implications, The Urban Inst. Just. Pol'y CTR. 51 (2013), http://www.urban.org/uploadedpdf/412831-Collecting-DNA-at-Arrest-Policies-Practicesand-Implications-Report.pdf; Matthies Goulka et al., Toward a Comparison of DNA Profiling and Databases in the United States and England, RAND CORP. (2010), http://www.rand.org/ content/dam/rand/pubs/technical_reports/2010/RAND_TR918.pdf.

68. See, e.g., Haskell, 669 F.3d at 1064 ("The mere existence of the DNA database creates a strong deterrent effect.... [I]t is much easier for a criminal to cover his fingerprints than it is to prevent any DNA from being left at a crime scene. A felony arrestee is less likely to commit another crime in the future if he knows that his DNA is catalogued in the State database." (citations omitted)). The DNA expunction laws in principle diminish the value of the latter interest to the police; however, as noted above, placing the burden of expungement on the arrestees ensures that 
To think about the correlation issue, I borrow the terms Kaye and Smith use: "target" crimes are those for which "biological trace evidence might be found" and retained in databases, and "collection" crimes are those that trigger DNA collection on arrest. ${ }^{69}$ The incentives created by DNA collection would not be fully collateral if signals of guilt for target crimes were correlated with signals of guilt for collection crimes. Whether such a correlation exists depends on what set of crimes trigger DNA collection, ${ }^{70}$ and on what police treat as a signal of guilt of the target crimes. A few considerations ought to create serious doubts about the relevant correlation.

Prior offenders are more likely to commit additional crimes than people who have never offended, and prior arrests are a strong predictor of future arrests. ${ }^{71}$ These regularities might suggest that, all else being equal, a person who is (accurately) believed to have committed crimes in the past is more likely to be guilty of another crime than a person who has no criminal past. If so, then police arresting suspected prior offenders because they hope to collect and match their DNA for some target crime may be statistically justifiable, a practice of statistical discrimination. This is, however, misleading: a criminal with particular criminal experience may not be more likely to commit a specific crime than either other criminals, or non-criminals.

Consider a case in which both the collection and target crime consist of rape only. Faced with two otherwise indistinguishable suspects, if police were to arrest the one with a prior rape history, they would be acting on a signal correlated with guilt of the new rape. However, matters become more complicated when the set of "collection" crimes is expanded: for example, suppose the target crime is still rape only, but collection crimes now include robbery, car theft, and gambling. A suspected rapist may be more likely to commit another rape, but he is not

many profiles remain. Paradoxically, the possibility that a profile has been expunged may create incentives to repeatedly arrest the same suspects for DNA collection, since collection at one point does not guarantee that the profile remains in the database.

69. D. H. Kaye \& Michael E. Smith, DNA Identification Databases: Legality, Legitimacy, and the Case for Population-wide Coverage, 2003 WIS. L. REV. 413, 420 (2003).

70. See supra note 48 and accompanying text.

71. See, e.g., Robert J. Sampson \& John H. Laub, Crime and Deviance in the Life Course, 18 ANN. REV. SOC. 63, 69 (1992) ("There is ample evidence that antisocial behavior is relatively stable across stages of the life course."); Patrick A. Langan \& David J. Levin, Recidivism of Prisoners Released in 1994, Bureau of Just. StAT. Special RePORT, NCJ 19342710 (June 2002), http:/www.aci-adc.com/images/Recidivism/RecidivismofPrisonersReleased1994.pdf ("The number of times a prisoner has been arrested in the past is a good predictor of whether that prisoner will continue to commit crimes after being released."). 
more likely to commit robbery, car theft, or gambling than someone with a different criminal history. Research finds that a degree of "specialization" exists for many common serious offenses. ${ }^{72}$ The rapist may still be more likely than a non-offender to commit one of these crimes, because there is some positive cross-correlation among different crimes. And for some crimes, serious prior offenders do not appear to have a statistical advantage: as the Bureau of Justice Statistics finds, convicts whose crimes warranted a prison sentence-i.e., the kinds of serious crimes for which traceable DNA evidence is likely to exist-are rearrested "almost exclusively for a felony or a serious misdemeanor." Yet, as more crimes qualify for collection, the correlation between the relatively static set of target crimes and the expanding set of collection crimes inevitably becomes weaker. And the incentives created by DNA collection do not lead police to focus only on suspected rapists when investigating rape or related crimes; they are, instead, incentives to focus on suspected criminals when contemplating arrest for any crime triggering DNA collection. ${ }^{74}$

Thus far, it has been assumed that police have a well-founded belief, though not based on legally sufficient evidence, that a specific person they arrest for a collection crime is also guilty of a target crime. It seems just as likely, if not more likely, that police may be influenced by the availability of DNA collection even in the absence of such a unique suspect. Suspects identified through CODIS have considerably longer criminal histories than suspects identified through other means. ${ }^{75}$ If police were to attempt to distinguish among suspects on the basis of their likelihood to turn up in CODIS one way or another, they would logically opt for the usual suspects, viewed as most likely to commit crimes repeatedly. The usual suspects, as many justifiably worry, are more

72. That is, a robber is more likely than others to commit robberies, which means a rapist is less likely than the robber to do so. For a quantification of specialization, see Langan \& Levin, supra note 71 .

73. Id. at 1 .

74. The relevant correlation is likely to become weaker as repeat offenders cycle through the system. The only group police would find useful to target is criminals who have either not been arrested post-collection law or had their samples expunged, but are nevertheless suspected of being uncaught repeat offenders.

75. In one study of 500 crime scenes, "[s]uspects identified using DNA evidence had substantially more serious criminal histories than those identified through traditional investigation. Suspects identified by DNA averaged 2.9 prior felony convictions and 5.6 prior felony arrests, compared with 0.9 prior felony convictions and 1.7 prior felony arrests for suspects identified using traditional investigation in the control group." John K. Roman et al., The DNA Field Experiment: Cost-Effectiveness Analysis of the Use of DNA in the Investigation of High-Volume Crimes, THE URBAN INST. 4 (Apr. 2008). 
often than not characterized in racial and class terms. ${ }^{76}$ Thus, the worries expressed by experts that "DNA collection triggered by any arrest quickly leads to a DNA database of men of color," 77 one that "reflects the race, class, and geographic biases embedded in police and judicial practices." $" 78$

Aside from the problem of race- and class-based inequalities, is there reason to think that selecting suspects on this basis correlates with arrest quality for any given collection crime? The extent to which race (or any comparable, broad social trait) correlates with repeat offending differs across crimes. As Sampson and Lauritsen note in their review of criminological studies, "there are certain offenses for which each [race] is overrepresented. For instance, Whites are disproportionately arrested for driving while intoxicated, and Asians are over-represented in arrests for illegal gambling. Blacks are consistently more likely to be arrested for crimes of violence," ${ }^{, 79}$ and as Morenoff adds, Blacks are underrepresented in other liquor law violations. ${ }^{80}$ Most studies on offense rates and reoffending are based on official statistics, which are likely to reflect existing law enforcement biases. ${ }^{81}$ Nonetheless, even with such biases, there are differences across crime types. Studies based on sources other than official data also show that Black youths are less likely to use drugs compared to other groups. ${ }^{82}$ In general, Black-White race disparities are greatest for violent crimes, and are less pronounced or absent for other crimes. ${ }^{83}$

As noted, target crimes for which crime scene samples are databanked are predominantly serious violent crimes. Collection crimes, however, are considerably broader in many jurisdictions, with initiatives to broaden them further afoot. ${ }^{84}$ Profiling on race because of its perceived correlation with serious violent criminal offending may

76. See Charis E. Kubrin \& Eric A. Stewart, Predicting Who Reoffends: The Neglected Role of the Neighborhood Context in Recidivism Studies, 44 CRIMINOLOGY 165, 166 (2006) (reviewing the empirical literature finding that minority offenders are more likely to recidivate).

77. Lapp \& Radice, supra note 6, at 175.

78. Cole, supra note 15 .

79. See Sampson \& Lauritsen, supra note 57, at 311, 325.

80. Morenoff, supra note 55, at 148.

81. See supra note 57.

82. Johnston et al., supra note 64 , at 7 .

83. Id.; Like-Haislip, supra note 63, at 126 (while it is "reasonable to conclude that minorities, particularly African Americans and American Indians, are disproportionately often serious crime ... offenders[,] [r]acial and ethnic variations are less pronounced for other crimes, such as illicit drug use and delinquent behavior").

84. See supra note 49. 
correlate with the probability of guilt of other violent crimes, but not with the probability of guilt for other collection crimes. ${ }^{85}$ Thus, as the set of collection crimes becomes broader, indicia of general suspicion of recurring criminality become less informative for more and more arrests. Since there are more arrests for minor than serious crimes, the incentives created by DNA collection laws, in jurisdictions where misdemeanors or all felonies trigger collection, are largely collateral. ${ }^{86}$

The consequences of these incentives are likely to resemble, in some respects, those of one familiar modern policing strategy. Frank Zimring describes the problem of "two-stage selection" in the context of aggressive street police tactics such as "hot spot" policing in New York City. ${ }^{87}$ As Zimring explains, "the street patrol officer is concentrating on potential robbers and burglars when selectively enforcing marijuana laws," and thus, "will select 'the usual suspects' not for pot but for street

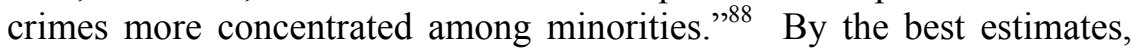
the rates of marijuana violations are not significantly different across races. ${ }^{89}$ And marijuana arrests under this policing strategy became distinctly racially skewed. ${ }^{90}$ As there is little evidence that robbers or burglars are more likely to be guilty of marijuana crimes than other people, hot spot policing involved police in a pursuit of an extrinsic benefit that was likely uncorrelated with the guilt for the crimes of arrest.

85. Some studies also found that minority offenders are more likely to specialize in an offense, which further suggests that profiling on one target crime is not an informative signal of guilt for different types of collection crimes. See Todd A. Armstrong \& Chester L. Britt, The Effect of Offender Characteristics on Offense Specialization and Escalation, 21 JusT. Q. 843, 862 (2004) (finding "that non-white offenders may show a relatively greater likelihood, when compared to white offenders, to specialize in a variety of offenses"); Christopher J. Sullivan, et al., Rethinking the "Norm" of Offender Generality: Investigating Specialization in the Short-Term, 44 CRIMINOLOGY 199, 210 (2006) (summarizing studies of distinctions in specialization patterns across race).

86. It is important to note that even limiting collection to felonies includes a very broad set of crimes. See, e.g., Brief for the ACLU et al. as Amici Curiae Supporting Respondent at 4, Maryland v. King, 133 S. Ct. 1958 (2013) (No. 12-207) ("California, for example, seizes and searches the DNA of everyone arrested for any felony, including crimes such as stealing $\$ 250$ worth of fruits or nuts from a farmer's field, unlawfully subleasing a car, or simple drug possession. The federal government takes DNA from persons arrested even for minor misdemeanors ....”).

87. Franklin ZimRIng, The City that Became SAFE 123 (2012).

88. Id.

89. See, e.g., Amanda Geller \& Jeffrey Fagan, Pot as Pretext: Marijuana, Race, and the New Disorder in New York City Street Policing, 7 J. EMPIRICAL Legal Stud. 591, 606 (2010) (citing evidence of comparable rates of marijuana use across races); Like-Haislip, supra note 63, at 118-20 (reviewing multiple studies based on two major national surveys, which consistently show lower rates of use of most illicit drugs by Black teenagers than by White teenagers).

90. See, e.g., Bernard E. Harcourt \& Jens Ludwig, Reefer Madness: Broken Windows Policing and Misdemeanor Marijuana Arrests in New York City, 1989-2000, 6 CRIMINOLOGY \& PUB. POL'Y 165 (2007); Golub et al., supra note 60. 


\section{Legal Independence of Arrest Quality}

Even if the likelihood of realizing an extrinsic benefit is uncorrelated with the likelihood of prosecution for the crime of arrest, a legal dependence of the former on the latter would discipline officers into making lawful arrests. In the case of marijuana arrests noted above, police are selecting arrestees on a basis not likely correlated with guilt. But if their goal is incapacitating supposed dangerous criminals, police have incentives to ensure that the arrests are at least lawful and maybe even prosecutable. To take another example, scholars and commentators have long criticized the search incident to lawful arrest (SILA) doctrine on the grounds that it encourages pretext arrests. ${ }^{91}$ The possible discovery of evidence of a (usually more serious) crime for which police lack a sufficient quantum of suspicion is an extrinsic benefit of making an arrest for a (usually minor) crime. Even if suspicion as to the more serious crime is a worthless signal of guilt of the crime of arrest, the police must still care about the lawfulness of the arrest to avoid the exclusion of any discovered evidence. While these extrinsic benefitsincapacitating dangerous offenders and discovery of evidence, respectively - may not be correlated with the guilt of the crime of arrest, they are still legally dependent on the quality of arrest.

While the relevant law is evolving, extrinsic benefits created by the immigration and at least some DNA screening regimes are largely legally independent of arrest quality. As Wayne Logan documents, information discovered as a result of screening has been treated as "identity evidence," a species subject to different rules from ordinary evidence. ${ }^{92}$ Thus, at present, it is uncertain that even an illegal arrest would imperil these benefits, and more likely that information discovered as a result of either screening regime can be used regardless of the arrest's legality.

91. See Wayne A. Logan, Street Legal: The Court Affords Police Constitutional Carte Blanche, 77 IND. L.J. 419, 441-42 (2002) ("[T] he per se authority to search upon any arrest provides officers a compelling, volume-based incentive to execute custodial arrests for minor offenses so that they can uncover evidence for 'good busts' (that is, those leading to more serious prosecutions)."); United States v. Robinson, 414 U.S. 218, 248 (1973) (Marshall, J., dissenting) (there is "always the possibility that a police officer, lacking probable cause to obtain a search warrant, will use a traffic arrest as a pretext to conduct a search").

92. Logan, supra note 15 , at 1587. 


\section{a. Immigration Screening}

The benefits of immigration screening are at present unrelated to the lawfulness of the arrest, because the screening typically occurs before the arrest's lawfulness is determined: fingerprints are taken at booking and a detainer may issue before the legal basis for the arrest is evaluated. ${ }^{93}$ Even if the arrest is not backed by probable cause, or charges are either not filed or dismissed, federal immigration officials may take custody of an arrestee and place him in deportation proceedings. ${ }^{94}$ While some confusion remains about the reach of INS v. Lopez-Mendoza, ${ }^{95}$ the key Supreme Court decision on point, as a general matter, even if the identification of an individual as an immigration violator was obtained through an unlawful arrest, his identity (including his immigration file) is not suppressible in a deportation hearing. ${ }^{96}$ Because even an unlawful

93. The independence of the merits of the arrest was a proverbial feature, not a bug. See DEP'T OF HOMELAND SEC., OfFice OF THE InSPECTOR GEN., OIG-12-64, OPERATIONS OF UNITED STATES IMMIGRATION AND CUSTOMS ENFORCEMENT'S SECURE COMMUNITIES 6 (Apr. 5, 2012), http://www.oig.dhs.gov/assets/Mgmt/2012/OIG_12-64_Mar12.pdf ("Earlier identification meant that ICE could remove aliens with prior convictions or immigration violations regardless of the current charges against them" (emphasis added)); see also Ingrid V. Eagly, Criminal Justice for Noncitizens: An Analysis of Variation in Local Enforcement, 88 N.Y.U. L. REV. 1126, 1150 (2013) ("Because immigration authorities have taken the position that federal deportation proceedings can effectively preempt local criminal prosecutions, sometimes defendants who post criminal bond will be deported before their criminal case is fully adjudicated.").

94. The DHS decision to initiate immigration proceedings often comes before any test or confirmation of police officers' finding of probable cause. See, e.g., United States v. Uriostegui, 420 F. Supp. 2d 1260, 1261-62 (M.D. Ala. 2006).

95. In Lopez-Mendoza, 468 U.S. 1032 (1984), one defendant challenged the use of his identity to commence deportation proceedings. Another defendant sought to have the evidence linking him to his immigration record suppressed. The Supreme Court rejected both claims on the grounds that " $[t]$ he 'body' or identity of a defendant or respondent in a criminal or civil proceeding is never itself suppressible as fruit of an unlawful arrest, even if it is conceded that an unlawful arrest, search, or interrogation occurred." Id. at 1039. As to the challenged identifications, the Court held that "evidence derived from ... [unlawful] arrests need not be suppressed in an INS civil deportation hearing." Id. at 1051. Confusion remains as to whether the "'body" or identity" statement quoted above "simply recognizes an established jurisdictional rule, i.e., that an unlawful arrest does not deprive a court of jurisdiction over the arrestee, or, instead, whether the statement establishes a blanket rule that a defendant's identity - and any evidence related to that identity-is never suppressible." United States v. Hernandez-Mandujano, 721 F.3d 345, 351 (5th Cir. 2013). The confusion mostly relates to the use of fingerprints and the immigration file to which they are linked in criminal cases.

96. In civil removal proceedings, courts read Lopez-Mendoza to mean that illegally obtained fingerprints and the immigration records recovered thereby are almost never excludable. See, e.g., The Role of the Exclusionary Rule in Removal Hearings, 126 HARV. L. REV. 1633 (2013); Jennifer M. Chacón, A Diversion of Attention? Immigration Courts and the Adjudication of the Fourth and Fifth Amendment Rights, 59 DUKE L. REV. 1563, 1624 (2010) (noting that "in many removal proceedings, the nature of the evidence illegally seized ensures that even when suppression occurs, the noncitizen will still be removable"). The Supreme Court in Lopez-Mendoza "left open the 
arrest will not ordinarily affect the outcome of a subsequent removal proceeding, ${ }^{97}$ the probability of the extrinsic benefit materializing does not legally depend on the quality of that arrest.

\section{b. DNA Collection}

The question of whether the interest in gathering DNA is dependent on the lawfulness of the arrest does not have an unambiguous or a uniform answer across jurisdictions. ${ }^{98}$ For instance, Maryland's DNA collection law allowed for the DNA sample to be taken right after arrest, but did not allow it to be processed or placed in a database before arraignment. $^{99}$ About a third of those states with such laws authorize collection and analysis only after a judicial determination of probable cause or an arraignment, which assures legal dependence; however, in close to two-thirds of such states collection occurs in the course of booking, before probable cause is determined. ${ }^{100}$

For the latter set of jurisdictions, would police lose the benefit of the DNA evidence if it is determined that the arrest is unlawful after a sample is taken, as suggested by some scholars? ${ }^{101}$ The benefits can be lost first through expungement (or expunction) of the profile and the

prospect that suppression may nonetheless be available in removal proceedings for egregious violations of the Fourth Amendment...." James L. Buchwalter, Unconstitutional Search or Seizure as Warranting Suppression of Evidence in Removal Proceeding, 40 A.L.R. Fed. 2d 489, ๆ 6 (2009). While some courts acknowledge that suppression may be available in cases of egregious violations, very few cases had actually found such violations. See, e.g., Pretzantzin v. Holder, 725 F.3d 161, 171 (2d Cir. 2013); Lopez-Rodriguez v. Mukasey, 536 F.3d 1012, 1015 (9th Cir. 2008); see also Chacón, supra note 96, at 1614 (discussing cases).

97. In deciding Lopez-Mendoza, the Court presumed that most arrests leading to deportation proceedings would be made by federal immigration officers (then INS), and that constitutional violations could be prevented by institutional internal discipline. See Lopez-Mendoza, 468 U.S. at 1044 (referring to the INS's "comprehensive scheme for deterring Fourth Amendment violations"). The introduction of Secure Communities (and prior similar initiatives) means that arrests triggering removal proceedings are now more commonly made by local and state law enforcers, which has led some to question the continuing vitality of Lopez-Mendoza. See, e.g., Chacón, supra note 96.

98. The Supreme Court explicitly declined to address the question whether such collection is still warranted if probable cause to arrest was absent because the Maryland law required a finding of probable cause for the arrest before DNA collection occurs. Maryland v. King, 133 S. Ct. 1958, 1967 (2013).

99. Md. Code AnN., Pub. SAfety §2-504(d)(1) (LexisNexis 2011).

100. Compare CAL. PENAL CODE $\S \S 296.1(\mathrm{a})(1)(\mathrm{A}), 299$ (West 2012) (mandating DNA collection immediately upon arrest), with 730 Ill. COMP. STAT. 5/5-4-3 (a-3.2) (2012) (calling for DNA collection within 14 days of indictment, a preliminary hearing finding probable cause, or a waiver of a preliminary hearing).

101. David H. Kaye, Drawing Lines: Unrelated Probable Cause as a Prerequisite to Early DNA Collection, 91 N.C. L. REV. ADDENDUM 1, 8-9 (2012). 
sample that should in principle follow a fruitless arrest. However, even if the arrestee were ultimately acquitted of the crime or never prosecuted, the DNA sample and profile are retained unless conditions set by the jurisdiction's expungement law are met. While in seven states the expungement of DNA profiles is the responsibility of state authority, most states place the responsibility for initiating expungement on the arrestee. ${ }^{102}$ As a matter of practice, when individuals bear the burden, few expungements occur. ${ }^{103}$

More directly, the police can also lose the benefit through suppression in a future prosecution for the crime discovered or solved through DNA screening, and in Maryland, whose DNA collection law was upheld in King, there is a statutory provision to that effect. ${ }^{104}$ North Carolina has a similar prohibition, and two other states have weaker provisions, prohibiting the use of DNA matches after the sample was ordered to be expunged. ${ }^{105}$ In the absence of statutory constraints, as Logan demonstrates, there is confusion surrounding the availability of the exclusionary remedy for "identity evidence," or evidence of who the person is and any kind of record to which he can be linked, ${ }^{106}$ based in part on Lopez-Mendoza and in part on Hudson v. Michigan. ${ }^{107}$

102. Samuels et al., supra note 67 , at 20 .

103. Id. at 18 (concluding on the basis of interviews with lab technicians and data provided by the states that "that expungements are rare in states where the individual bears the burden"); see also People v. Buza, 180 Cal. Rptr. 3d 753, 761-62 (Cal. Ct. App. 2014) (“The expungement process ... is neither quick nor guaranteed... The arrestee must submit a request to the trial court and prosecutor of the county where the arrest occurred and to the DOJ's DNA Laboratory; the court must then wait 180 days before it can grant the request; the court has discretion to grant or deny the request and its order is not reviewable by appeal or by writ. The DNA Act appears to allow the prosecutor to prevent expungement merely by objecting to the request." (citations omitted)); for an overview of state expungment procedures and an argument for automatic expunction, see Catherine A. Burke, Suspicionless DNA Collection from Arrestees Violates the Fourth Amendment, but Easier Expunction of DNA Records Can Help Mitigate the Harm (Jan. 9, 2013) (unpublished manuscript), available at $\mathrm{http}$ ://papers.ssrn.com/sol3/papers.cfm?abstract_id=2261499.

104. Md. Code. AnN., Pub. SAfETy $§ 2-511$ (West Supp. 2011).

105. Ala. CODE § 36-18-25 (2013); COlO. ReV. StAT. § 16-23-105 (Supp. 2013); N.C. GEN. STAT. § 15A-266.3A (Supp. 2013).

106. Logan, supra note 15, at 1581-86. Most cases addressing the issue of identity evidence deal with fingerprints, but many courts presume a "clear analogy between fingerprinting and DNA identification under the DNA Act." Haskell v. Harris, 669 F.3d 1049, 1060 (9th Cir. 2012). Case law dealing specifically with DNA and cold hits has yet to take shape. For an overview of identity evidence cases generally, see LAFAVE, supra note 16 , at $\S 11.4(\mathrm{~g})$.

107. For a discussion of Lopez-Mendoza, see supra note 95; Hudson v. Michigan, 547 U.S. 586, 591 (2006) (the exclusionary rule is "applicable only "where its remedial objectives are thought most efficaciously served'- that is, "where its deterrence benefits outweigh its substantial social costs." (citations omitted)). 
Some courts will suppress the identity of the defendant selectively, only if an illegal arrest "was purposefully exploited for the objective of obtaining fingerprints," " courts hold flatly that "the exclusionary rule does not apply to evidence to establish the defendant's identity in a criminal prosecution." 109 Since the defendant's "identity" has come to include not just the name and vitals, but also the criminal history to which his identity matches, under this approach, a DNA match discovered after an illegal arrest can still be used to support prosecution. In sum, in those jurisdictions where collection is permitted at booking and expungement is not automatic, the probability of an unlawful arrest compromising the expected benefit of a DNA match is low. ${ }^{110}$

\section{Institutional Independence of Arrest Quality}

Even if the extrinsic benefit is uncorrelated with and legally independent of arrest quality, its pursuit may be curtailed by institutional discipline. Scholars such as Nirej Sekhon and Rachel Harmon have recently drawn attention to the importance of departmental discretion in shaping arrest patterns. ${ }^{111}$ For instance, police departments determine the geography of enforcement and may use their discretion to police minority neighborhoods more intensely, resulting in unwarranted

108. United States v. Olivares-Rangel, 458 F.3d 1104, 1115-16 (10th Cir. 2006); see also United States v. Garcia-Beltran, 389 F.3d 864, 865 (9th Cir. 2004).

109. United States v. Farias-Gonzalez, 556 F.3d 1181, 1189 (11th Cir. 2009). As noted supra note 95, there is disagreement as to whether Lopez-Mendoza "simply recognizes an established jurisdictional rule ... or, instead, whether the statement establishes a blanket rule that a defendant's identity - and any evidence related to that identity - is never suppressible." United States v. Hernandez-Mandujano, 721 F.3d 345, 351 (5th Cir. 2013) (Jolly, J., concurring). Three Circuits concluded that a defendant's identity is never suppressible. See United States v. Bowley, 435 F.3d 426, 430-31 (3d Cir. 2006); United States v. Navarro-Diaz, 420 F.3d 581, 588 (6th Cir. 2005); United States v. Roque-Villanueva, 175 F.3d 345, 346 (6th Cir. 1999). Four other Circuits interpreted Lopez-Mendoza as stating purely a jurisdictional rule. See Pretzantzin v. Holder, 725 F.3d 161, 166-67 (2d Cir. 2013); United States v. Oscar-Torres, 507 F.3d 224, 228-29 (4th Cir. 2007); Olivares-Rangel, 458 F.3d at 1106; United States v. Guevara-Martinez, 262 F.3d 751, 754 55 (8th Cir. 2001).

110. This conclusion pertains to both the interest in a "cold hit" and an interest in populating the database to increase chances of a "future" match. If a DNA match occurs far in the future, presumably the unlawful arrest that led to the extraction of the sample may be challenged and adjudicated under the same legal principles. It is even more unlikely that suppression will result for such a distant future match on account of the "attenuation of taint" doctrines.

111. Sekhon, supra note 38; Harmon, supra note 35, at 805 ("[I]nternal processes provide the most commonly used remedy for misconduct and, in many jurisdictions, interact with other remedies, such as ... external review of administrative remedies by an auditor or civilian oversight agency.”). 
disparities in arrest rates. Likewise, agency-level receptivity to collateral benefits would loosen the disciplinary constraints on individual officers' pursuit thereof, contrary to the hopes of the Supreme and lower courts.

Consider an officer with idiosyncratic personal preferences, such as animus towards some identifiable social groups. Even if that officer himself does not value lawful or fruitful arrests, he is likely to be constrained from acting on his preferences. Because the extrinsic benefit - the psychic satisfaction of harassment - accrues only to the officer, and the wasted arrests impact the departmental record, such an officer is likely to be disciplined by his department. Departmental discipline may not nullify the extrinsic benefit, but it is a cost to the arresting officer that diminishes the expected value of the arrest.

By contrast, an LEA that is interested in the extrinsic benefit is unlikely to sanction its officers for pursuing that benefit. At the extreme, consider an agency that itself sets up collateral incentives by encouraging arrests for non-prosecutorial purposes such as order maintenance and street control: officers in such an agency are unlikely to suffer any discipline for illegal arrests made pursuant to this policy. ${ }^{112}$

While LEAs may not overtly encourage arrests for the sake of deportations, LEAs' interest in immigration enforcement predates Secure Communities. Certainly not every LEA would be equally accommodating of its officers' pursuit of this collateral benefit. ${ }^{113}$ Yet, an active interest in immigration enforcement over the past fifteen or so years on the part of some LEAs has been documented and analyzed in "crimmigration" scholarship. ${ }^{114}$ Within the past decade, some LEAs have voluntarily participated in immigration enforcement under the auspices of federal-local partnerships, of which the so-called " $287(\mathrm{~g})$ " programs and the Criminal Alien Program (CAP) are most prominent. ${ }^{115}$

112. For a real example of such dynamics, see, for example, Bielevicz v. Dubinon, 915 F.2d 845,849 (3d Cir. 1990) (describing policy of routine arrests for public intoxication for social control reasons with no intention of prosecution in Pittsburgh, and reporting that "[n]ot only were no safeguards implemented to prevent illegal arrests for public drunkenness, but the City also followed an express policy of not investigating - or even accepting — complaints regarding alleged pretextual arrests under the charge.... [R] eports of illegal public intoxication arrests were the only category of complaints that his Office did not accept").

113. See Eagly, supra note 93 (demonstrating that LEAs differ in their approaches towards immigration enforcement).

114. See, e.g., Chacón, supra note 96, 1579-95 (2010); Cristina M. Rodriguez, The Significance of the Local in Immigration Regulation, 106 MICH. L. REV. 567, 591-92 (2008).

115. Section $287(\mathrm{~g})$ of the Immigration and Nationality Act authorizes the Secretary of Homeland Security to deputize and train local law enforcement agencies to perform certain functions of federal immigration officers, at local expense. 8 U.S.C. $\$ 1357$ (g) (Supp. 2014). The Criminal 
Moreover, some LEAs adopted unilateral policies of contacting ICE when a foreign-born person is encountered in the course of other enforcement activities. ${ }^{116}$ A survey of 489 agencies carried out largely prior to the automation of immigration screening, for example, finds that a large share of law enforcement agencies went to the extra effort of initiating immigration status inquiries: $87 \%$ of police chiefs and $89 \%$ of county sheriffs reported a policy or practice of checking immigration status for those arrested for a violent crime, and 51\% and $67 \%$ respectively, for first-time offenders arrested for a nonviolent crime. ${ }^{117}$ Some law enforcement organizations such as the National Sheriffs' Association and the Major County Sheriffs' Association publicly supported local involvement in enforcement, and approved of the automation of immigration information. ${ }^{118}$

Likewise, law enforcers have long expressed interest in using biometric information to facilitate their ability to match offenders to unsolved offenses. In an earlier era, law enforcement moved swiftly to create a universal fingerprint database, and conducted fingerprint "drives," asking citizens to volunteer their fingerprints. ${ }^{119}$ The same has occurred with DNA, as police resort to "dragnets" seeking consent from people to provide their DNA to the police in the interest of more

Alien Program (CAP) is predominantly carried out by federal officers, but relies on local actors to facilitate ICE access to foreign-born inmates. See Doris Meissner et al., Immigration Enforcement in the United States: The Rise of a Formidable Machinery, 2013 Migration Policy Inst. 1, 105 (2013), available at http://www.migrationpolicy.org/research/immigration-enforcement-unitedstates-rise-formidable-machinery.

116. E.g., Miranda-Olivares v. Clackamas Cnty., No. 3:12-cv-02317-ST, 2014 WL 1414305, at *1 (D. Or. Apr. 11, 2014) (Clackamas County Jail had a "policy of notifying ICE when a foreign born [sic] person is brought to the Jail on a warrant or probable cause charge"). The section of Arizona's SB 1070 that contained such a policy was the only one to survive the constitutional challenge in Arizona v. United States, 132 S. Ct. 2492, 2507-10 (2012). See ArIZ. Rev. Stat. AnN. $\S 11-1051$ (B) (2012) (requiring state officers to make a "reasonable attempt ... to determine the immigration status" of any person they stop or arrest on some other legitimate basis if "reasonable suspicion exists that the person is ... unlawfully present in the United States," and provides that "[a]ny person who is arrested shall have the person's immigration status determined. ...").

117. Varsanyi et al., supra note 40.

118. Memorandum from the Major County Sheriffs' Ass'n to Members of Congress (June 20, 2013), http://www.mcsheriffs.com/pdf/news/mcsa_immigration_position_paper_final.pdf; Position Paper on Comprehensive Immigration Reform, 2013 NAT'L SHERIFFS' ASS'N 1, 2 http://www.sheriffs.org/sites/default/files/uploads/documents/GovAffairs/NSA\%20CIR\%202013\%2 0FINAL.pdf (asking for “[i]ncreased funding for ICE's Criminal Alien Removal Programs, such as 287(g) and Secure Communities"). By contrast, some police organizations are more ambivalent. E.g., Law Enforcement Leaders Oppose Federal Mandate to Engage in Immigration Enforcement, 2013 NAT'L IMMIGRATION LAW CTR. 4, http://democrats.judiciary.house.gov/sites/demo crats.judiciary.house.gov/files/documents/LEA1307.pdf.

119. See Cole, supra note 15 , at 12 . 
effective law enforcement. ${ }^{120}$ LEAs are also engaged in creating local "rogue" DNA databases that are not subject to laws governing the use of CODIS. ${ }^{121}$ Proponents of DNA collection laws are explicit that the purpose of these laws is to fight crime and resolve open cases, rather than mere identification, the interest identified by the Supreme Court. ${ }^{122}$ Almost all of Maryland's 130 LEAs supported the DNA collection law on the grounds that the state's "compelling interest in entering and maintaining DNA information in CODIS" is geared towards the "detect[ion of] recidivist acts and actors," location of "missing and unidentified persons," and even "deterring crime" via "[n]ews reports of successful investigations," in addition to identification of arrestees. ${ }^{123}$ Populating the database or solving cold cases is the kind of benefit that redounds to the agency as a whole, and is likely to compensate for lower quality arrests. Disciplinary measures for the potentially unlawful arrest influenced by the prospect of DNA collection should not be frequent.

In sum, Secure Communities and at least some DNA collection laws set up incentives to arrest on bases uncorrelated with arrest quality. And benefits they provide are largely legally and institutionally independent of the same. With regard to DNA collection laws, the most problematic are jurisdictions that both have expansive sets of collection crimes, do not require a finding of probable cause before collection or analysis, and do not provide for automatic expungement: at present, this set consists of

120. E.g., Kohler v. Englade, 470 F.3d 1104, 1107 (5th Cir. 2006) (case arising out of an investigation that involved asking over " 600 men... to collect oral saliva swabs for DNA comparison."); Troy Duster, DNA Dragnets and Race: Larger Social Context, History, and Future, 21 GenEWATCH 1, at 3 (Dec. 2008), http://www.councilforresponsiblegenetics.org/Gene Watch/GeneWatchPage.aspx?pageId=56\&archive=yes (describing several large-scale dragnets for DNA samples).

121. See e.g., David M. Jaros, Preempting the Police, 55 B.C. L. REv. 1149, 1777 (2014); Joseph Goldstein, Police Agencies are Assembling Records of DNA, N.Y. TIMES (June 12, 2013), http://www.nytimes.com/2013/06/13/us/police-agencies-are-assembling-records-of-dna.html? pagewanted=all.

122. E.g., Maryland v. King, 133 S. Ct. 1958, at 1985 (2013) (Scalia, J., dissenting) ("The Governor of Maryland, in commenting on our decision to hear this case, said that he was glad, because "[a]llowing law enforcement to collect DNA samples ... is absolutely critical to our efforts to continue driving down crime,' and 'bolsters our efforts to resolve open investigations and bring them to a resolution."').

123. Brief of Md. Chief of Police Ass'n et al., at 9-10, 12, Maryland v. King, 133 S. Ct. 1958 (2013) (No. 12-207), 2013 WL 179942, at *9-10, 12. Indeed, in the opinion of the California Court of Appeals, which invalidated California's DNA collection law, "DNA taken at the time of arrest is not intended to be used, and cannot usefully be employed, to verify the arrestee's identity; it is intended to be used and is in fact employed to investigate the arrestees' possible involvement in criminal conduct unrelated to the crime of arrest and to add to the DNA database for purposes of future crime-solving." People v. Buza, 231 Cal. App. 4th 1446, 1480 (2014). 
Alabama, ${ }^{124}$ Arizona, Kansas, Louisiana, South Carolina, and South Dakota, all of which collect for some misdemeanors; and Alaska, North Dakota, and Ohio, all of which collect for all felonies. ${ }^{125}$ These database-screening regimes are not the only or first policy innovations that set up systematic collateral incentives. ${ }^{126}$ A nationally-available fingerprint database was among the first innovations to present similar concerns: it enabled police to learn about arrestees' criminal records and outstanding warrants, and to facilitate future investigations by matching latent fingerprints from the crime scene to existing records. ${ }^{127}$ Moreover, collateral incentives are not limited to technological innovations. Certain "New Policing"" 28 strategies also generate such incentives. Insofar as "zero tolerance" or "order maintenance" policing aims primarily to demonstrate police intolerance for visible public-order violations, police are led to discount the intrinsic value of arrests. ${ }^{129}$ If the dominant aim of

124. Alabama's law is not a paradigmatic involuntary collection law, in that it appears to allow arrestees to refuse to provide a sample without penalty. ALA. CODE $\S 36-18-25$ (2013). It is less clear that arrestees are made aware of their right to refuse, or how common such refusals are as a matter of practice.

125. See NCSL, supra note 48. California's law, which authorized collection and analysis for all felonies prior to the determination of probable cause and did not provide for automatic or easy expungement, was declared unconstitutional under state law. As that California court noted, independence of the quality of the arrest was one of the dangers of the law: "there is no check on the discretion of the officers who make the arrests that create the opportunity for DNA sampling until after the sample may have been used for investigative purposes.” Buza, 231 Cal. App. 4th at 1489.

126. For example, judges worried in 1987 that "[c]urrent technology" would enable officers "who desire to arrest an individual" to do so by "merely leaf[ing] through the files or turn[ing] to the computer to determine whether they can find some reasons to arrest a suspect for whose arrest they otherwise lack probable cause." United States v. Causey, 834 F.2d 1179, 1189-90 (5th Cir. 1987) (Rubin, J., dissenting).

127. See Cole, supra note 15 , at 63-89.

128. See Philip B. Heymann, The New Policing, 28 Fordham UrB. L.J. 407 (2000) (using "New Policing" to describe a complex of policing strategies including "Broken Windows," hot-spot policing, community policing, and zero tolerance, among others).

129. The extrinsic, symbolic value of arrests under order maintenance strategies to signal police readiness to enforce the law generally may be gleaned from James Q. Wilson and George L. Kelling's renowned article. George L. Kelling \& James Q. Wilson, Broken Windows: The Police and Neighborhood Safety, ATLANTIC MonTHLY (Mar. 1, 1982), http://www.theatlantic.com/ magazine/archive/1982/03/broken-windows/304465/?single_page=true. To deter "serious street crime," they argued, it is important to disrupt unserious "disorderly behavior" by "the rowdy teenager, or the importuning beggar." Id. Some police departments interpreted theories such as Kelling and Wilson's to mean that arrests for disorderly behavior will prevent serious crimes; thus, many "New Policing" strategies relied on arrests for extrinsic reasons. See, e.g., Heymann, supra note 128, at 429 (Noting that “'Broken Windows' policing . . justified very large numbers of ... misdemeanor arrests"). To be sure, such an interpretation is not inevitable, as many experts, including Kelling and Wilson themselves, have argued that Broken Windows strategies are best pursued without resorting to arrests. See Architect of Broken Windows Defends His Theory (Jan. 26, 2015), http:/www.thetakeaway.org/story/revisiting-broken-windows-theory/ ("The idea that 'broken windows' is, at least as I perceived it and have worked to implement it, that it's focused on 
the police is to get disorderly people off the street, whether charges for violating any specific law are sustainable becomes less important. ${ }^{130}$

By contrast, other motivations for arrests, even if normatively dubious, do not present the same systematic challenges as collateral incentives. Idiosyncratic personal preferences, such as animus towards identifiable social groups, may present an extrinsic psychic benefit to particular officers, but the benefit should at some point be outweighed by the cost of departmental discipline. SILA doctrine may create incentives to arrest in hopes of finding evidence of other crimes, but the pursuit of that benefit is legally constrained by the exclusionary rule. And not all New Policing strategies predicated on an extrinsic benefit of arrests create collateral incentives. For example, New York Transit Police's famous policy of combatting significant subway crime by arresting farebeaters did not present truly collateral incentives. In that context, the explicitly acknowledged extrinsic benefit - catching subway robberswas in fact correlated with guilt of fare-beating: "most subway robbers weren't paying the fare, and a good number of them were caught" through this strategy. ${ }^{131}$ Although these, and many other, considerations routinely influence arrest decisions, unlike collateral incentives, these phenomena are more amenable to the traditional, quality-based constraints that channel discretion, and should not be expected to systematically skew arrest outcomes.

\section{The PURPose OF ARREST AND DisCRETIONARY POWER}

So far, I have posited that the core purpose of arrests is prosecutorial, and implied that deviations from that purpose are misuses of arrest authority. This Part offers historical and jurisprudential support for that

getting arrests is really a serious misconception.” (quoting Kelling)).

130. For instance, Wilson and Kelling recount an example of a Newark officer engaged in such policing: "Drunks and addicts could sit on the stoops, but could not lie down. People could drink on side streets, but not at the main intersection... Persons who broke the informal rules ... were arrested." Id. For empirical evidence that this strategy led police to discount arrest quality, see Jeffrey Fagan and Garth Davies, Street Stops and Broken Windows: Terry, Race, and Disorder in New York City, 28 FoRdHAM URB. L.J. 457, 476 (2000) ("The result [of order-maintenance policing, or OMP] was a vast increase in misdemeanor arrests, but also a sharp decline in their quality and sustainability in court. ... As arrests increased under OMP, the rate at which prosecutors declined to pursue these cases rose dramatically.").

131. See William Bratton, Great Expectations: How Higher Expectations for Police Departments Can Lead to a Decrease in Crime, in MEASURING What MATTERS, NAT'L INST. OF JUSTICE, 13 (July 1999), https://www.ncjrs.gov/pdffiles1/170610-1.pdf (pointing out the dramatic decreases in the rates of subway crime). 
proposition, and articulates the normative problem presented by collateral incentives to arrest.

\section{A. Discretion and the Prosecution Principle}

Discretion wielded by law enforcers has long attracted scholarly attention. ${ }^{132}$ Whether discretion is intentionally vested in the hands of a state actor, ${ }^{133}$ or exists of necessity, ${ }^{134}$ how it is used is rarely a matter of indifference. An express grant or toleration of pure discretion, unguided by principle or standards, is rare, and seems on its face to be anathema to the rule of law. Instead, an actor vested with discretionary authority is ordinarily guided by some public interest or purpose. The relevant purpose could be broadly or narrowly defined. For instance, in making bail decisions, the judicial officer is typically directed to use his discretion to advance the "primary purpose of bail," which is to assure the charged individual's appearance in court. ${ }^{135}$ In other contexts, the actor is expected to use his discretion towards the end of doing "what is just and proper under the circumstances,"136 such as in the case of prosecutorial discretion. Whether narrowly or broadly defined, some uses of discretionary authority are clearly contrary to the purposes guiding that authority. Thus, an abuse of discretion occurs when

132. The scholarly literature is too vast and rich to do it justice in a footnote. For a few classic works of lasting influence dealing with police discretion, see KENNETH CULP DAVIS, POLICE Discretion (1975); SAmuel Walker, TAming the System: The Control of Discretion in CRiminal Justice 1950-90 (1993); EgON BitTner, Aspects OF POLICE WORK (1990).

133. For a virtue-based defense of discretion, see Josh Bowers, Legal Guilt, Normative Innocence, and the Equitable Decision Not to Prosecute, 110 COLUM. L. REV. 1655, 1669 (2010) (articulating a defense of discretion on "aretaic" grounds of "moral particularism"); on the inevitability of discretion, see William J. Stuntz, The Pathological Politics of Criminal Law, 100 MICH. L. REV. 505, 580 (2001) ("Even in a world where all crimes are to be enforced across the board, across-the-board enforcement cannot mean that everyone is arrested. Someone must identify the system's targets," and "careful review of each" is virtually impossible); on the social optimality of discretion, see Steven Shavell, Optimal Discretion in the Application of Rules, 9 AM. L. \& ECON. REV. 175, 176 (2007) ("If it would be socially desirable for decisions to depend upon the information bound up in the unincluded variables [i.e. not specified in the law], giving discretion to [officials] may be beneficial.").

134. Discretion exists of necessity because it is impossible to craft any rule that precludes the need for judgment or decision.

135. E.g., People v. Norman, 252 Cal. App. 2d 381, 411-12 (Cal. Ct. App. 1967). State penal codes commonly provide for specific considerations that ought to weigh in the judges' decision, for example, CAL. Penal CODE $§ 1275$ (a)(1) (West Supp. 2014) ("In setting, reducing, or denying bail, a judge ... shall take into consideration the protection of the public, the seriousness of the offense charged, the previous criminal record of the defendant, and the probability of his or her appearing at trial or at a hearing of the case.").

136. See, e.g., Burdeshaw v. Snell, 365 F. Supp. 2d 1194, 1202 (M.D. Ala. 2005). 
authority that is legally allotted to an actor is manifestly used to thwart the values that justified that authority. Some abuses of discretion are sanctionable by law but many lesser abuses - or, to use a broader term, misuses - of it are not.

Discretionary authority involved in arresting is multi-dimensional. The particular concern in this article is with the individual officer's affirmative decision to make a custodial arrest, rather than taking another enforcement action or no action. While the law of arrest differs in its particulars across jurisdictions, it leaves that decision largely to the discretion of the arresting officer, once the criteria legally justifying an arrest are met. ${ }^{137}$ The purposes that should guide police discretion in this respect are rarely made explicit. It is easy enough to state what justifies an arrest as a legal matter, but not for what reasons, and on the basis of what considerations such arrests ought to be made. As Surell Brady observes, "the purposes of arrest often are unarticulated, the standards for the exercise of the decision to arrest are virtually nonexistent, and the requirement of a nexus between millions of arrests and legitimate state interests does not exist." $" 138$

The lack of an articulated standard should lead us neither to the conclusion that there are no guiding principles for the discretion to arrest, nor to the conclusion that the guiding principles are as broad as a directive to pursue the "public interest." Indeed, to many influential scholars active through the 1960s, such as Wayne LaFave, it appeared to have been more or less settled that arrests "made for purposes other than the sole legitimate objective of prosecution" represented misuses of the discretion to arrest. ${ }^{139}$ As Frank Remington put it, "[i]n the 1960s the formal law seemed clearly to say that the police responsibility was to arrest those who violate the law, not to decide if and when to enforce the criminal code. The formal law also seemed to say, although less clearly,

137. For felony arrests, the legal requirement is at minimum probable cause for an arrest in public, and a warrant for an arrest inside the home. Legal standards for misdemeanor arrests differ across jurisdictions, with some retaining the requirement that the misdemeanor be committed in the presence of the officer to justify arrests. Some statutes further spell out what officers should consider in deciding whether to cite or make a custodial arrest for minor violations or misdemeanors, once the decision to take some enforcement action is made. E.g., KY. REV. STAT. § 431.015 (West Supp. 2013) (officer should issue a citation instead of an arrest "if there are reasonable grounds to believe that the person ... will appear to answer the charge.").

138. Surell Brady, Arrests Without Prosecution and the Fourth Amendment, 59 MD. L. REV. 1, 27-28 (2000).

139. LAFAVE, supra note 16, at $§ 9.1(\mathrm{e})$; WAYNE R. LAFAVE, ARREST: THE DECISION TO TAKE A SUSPECT INTO CUSTODY 438 (1965) [hereinafter LAFAVE, ARREST] (suggesting that "the practice of arresting for purposes other than prosecution," although common, is "not authorized by law"). 
that the only proper function of arrest was to take custody of an offender for purposes of prosecution." 140 The decision to arrest, in other words, should always be made at least in contemplation of prosecution.

What does it mean to say that arrest decisions ought to be guided by an interest in prosecution? At the very least, it implies the following propositions. The officer should intend to complete all the procedural steps required of him to ensure that the arrestee can be prosecuted. One thing that is inevitably required of him is a showing of the evidentiary basis to believe the arrestee committed the crime for which he is arrested. Because the evidence on the basis of which the arrest was made should support prosecution, the contemplated charges should be for the conduct on the basis of which the arrest is made (if not precisely for the offense identified by the arresting officer). Arresting for the purpose of prosecution implies further that considerations irrelevant to prosecution are improper grounds on which to base arrest decisions. To the extent an officer is basing his decision to arrest on something irrelevant to prosecution, he is not acting in the interests of the latter purpose. What considerations are irrelevant to prosecution is a complex question, but it can be answered in the abstract without classifying each factor that ever influenced arrest decisions. Relevant considerations likely go beyond those facts that comprise probable cause strictly speaking, but evidentiary reasons that signal probability of guilt and culpability are plainly relevant. The suspect's astrological sign, place of origin, or officer's personal animosity are plainly not, unless these factors somehow figure in the description of a specific suspect. ${ }^{141}$ I will refer to the claim that decisions ought to be guided by an interest in prosecution as the "prosecution principle" for short.

Even prior to the 1960s, when LaFave and Remington asserted the viability of the prosecution principle as a matter of law, police routinely made arrests for other purposes and on irrelevant bases. ${ }^{142}$ Police certainly do so today, and the law provides for almost no real sanctions for so doing. And prosecution does not actually follow a very high share

140. Frank J. Remington, LaFave on Arrest and the Three Decades That Have Followed, 1993 U. ILL. L. REV. 315, 316 (1993).

141. Difficult questions might be asked about characteristics such as unemployment, appearance, or bad character, which might raise the probability of charges and a successful prosecution as an empirical matter, but are irrelevant as a matter of law. For the present purposes, I sidestep these concerns and presume these kinds of factors are irrelevant to the likelihood of successful prosecution.

142. LAFAVE, ARREST, supra note 139, at 438 (documenting a variety of non-prosecutorial purposes for arrests). 
of arrests. One might conclude that the prosecution principle articulated by LaFave, Remington, and others has no relevance for contemporary policing. This, I suggest, is an unwarranted conclusion.

While legislative action has explicitly extended the permissible purposes of arrests to a limited extent, the prosecution principle retains normative force in policing jurisprudence. What changed over time are the legal consequences of arrest made in contravention of that principle. In the following sections, I offer a reductive account of the origins and evolution of the prosecution principle in jurisprudence, to demonstrate its contemporary relevance. In an era when officers had little occasion for discretionary decisions, that principle generated robust, enforceable limits on arrest practices. With the emergence of modern professional police forces and the increasing scope for police discretion, the legal limits on arresting behavior deriving from that principle became quixotic, and faded away. The prosecution principle as normative principle, however, persists in the background of policing and criminal jurisprudence as a guide for police discretion, rather than a legal mandate. Instead of legally sanctioning contrary arresting behavior as in the past, the prosecution principle is now best viewed as channeling arresting behavior towards the same ends. The prosecution principle is an aspiration. ${ }^{143}$ As such, it is not a demand that police act on the purest of motives, but solely that they be guided by it in the absence of explicit legislative authorization to arrest for other purposes. That aspiration is evoked when the Supreme Court refers to "the state of mind which is hypothecated by the reasons which provide the legal justification for the officer's action" ${ }^{144}$ in the context of arrests.

143. Nonetheless, some scholars have made or implied reasonable arguments that the principle is implicit in the Fourth Amendment or the Due Process guarantees. See Brady, supra note 138, at 27-28 (arguing that the Fourth Amendment requires that arrests constitute unreasonable seizures if the state as a whole is not willing or capable of prosecuting most arrestees). Thomas Davies has consistently argued that "the historical record actually indicates that the American Framers intended to preserve common-law arrest and search standards - standards that appeared to be settled and uncontroversial during the framing era-in the 'law of the land' and 'due process of law' clauses ... and in the 'due process of law' clause of the federal Fifth Amendment." Thomas Y. Davies, How the Post-Framing Adoption of the Bare-Probable-Cause Standard Drastically Expanded Government Arrest and Search Power, 73 LAw \& ConTEMP. PROBS. 1, 4-5 (2010) [hereinafter Davies, Bare-Probable-Cause]; Thomas Y. Davies, Correcting Search-and-Seizure History: NowForgotten Common-Law Warrantless Arrest Standards and the Original Understanding of "Due Process of Law”, 77 Miss. L.J. 1, 9 (2007) [hereinafter Davies, Correcting History]. If Davies is correct, then the prosecution principle, part of that common-law arrest law, is also one which the Framers intended to preserve.

144. Scott v. United States, 436 U.S. 128, 138 (1978). 


\section{B. The Evolution of the Prosecution Principle}

1. The Reign of the Prosecution Principle

The common law of arrest, as it stood during the Founding era, offered little room for discretion with regard to arrest - and thus, little room for the misuse of discretion. Common law definitions of arrests were explicit that this deprivation of liberty is intended to make possible the prosecution of criminals for their crimes. Blackstone defined arrest as "the apprehending or restraining of one's person, in order to... answer to an alleged or suspected crime." 145 The authority of constables, the early law enforcers, was largely ministerial: they were tasked with the execution of judicial warrants and did not conduct criminal investigations. ${ }^{146}$ Constables as well as private individuals did have a limited authority to make warrantless arrests on their own initiative. However, these occasions presented few opportunities to freely decide whether or not to arrest, and all the incentives favored arrests that would lead to prosecution and conviction.

Warrantless arrest authority was predicated on the crime having been committed in fact. ${ }^{147}$ Constables and private persons were authorized to arrest for a felony if the arrested person was actually guilty - that is, eventually convicted, or for a felony committed in fact in their presence, or if the felony was committed in fact and there was a "probable cause of suspicion" that the arrestee committed it. ${ }^{148}$ Thomas Davies offers convincing evidence that "warrantless misdemeanor arrests were limited to instances in which the guilt of the arrestee was plain because the arresting person actually witnessed the commission of the offense-the 'committed-in-the-presence-of' requirement," and the misdemeanor was an on-going "breach of the peace." 149

145. 4 William Blackstone, COMmentaries *289 (emphasis added).

146. Davies, Correcting History, supra note 143, at 28 ("Constables, the primary peace officers of that period, did not possess the sort of discretionary ex officio arrest authority that modern police officers exercise.... [T] he constable acted with the full authority ... of the law only when he acted pursuant to a judicial warrant." (emphasis added)).

147. Thomas Y. Davies, The Fictional Character of Law-and-Order Originalism: A Case Study of the Distortions and Evasions of Framing-Era Arrest Doctrine in Atwater v. Lago Vista, 37 WAKE FOREST L. REV. 239, 321 (2002) [hereinafter Davies, Fictional Originalism] ("no arrest could be lawful unless it was based on a sworn accusation that a specific crime had been committed in fact"').

148. Thomas Y. Davies, Recovering the Original Fourth Amendment, 98 MicH. L. REv. 547, 631-34 (1999) [hereinafter Davies, Original Fourth Amendment].

149. Davies, Fictional Originalism, supra note 147, at 324-25 (2002) (citing sources). 
Constables or private individuals were severely constrained in their ability to decide when to make an arrest and for what purpose. Warrantless arrests that were legally justified were often also mandated. With regard to felonies, in Blackstone's words, "[a]ny private person (and $\alpha$ fortiori a peace-officer) that is present when any felony is committed is bound by the law to arrest the felon."150 While witnessed felonies gave rise to a duty to arrest, arrests for unwitnessed felonies presented a risk of liability in trespass for an unlawful arrest, as well as lawful resistance by the arrestee. ${ }^{151}$ Liability for unlawful arrests was even broader for misdemeanors. ${ }^{152}$ Thus, the decision whether or not to make an arrest in any given instance was greatly limited by these duties and liabilities.

It was also taken for granted that a lawful arrest would be promptly followed by prosecution. ${ }^{153}$ The committal procedure employed at the time required that anyone who made a felony arrest:

promptly take the arrestee to a justice of the peace for the justice to decide whether to bail the arrestee, commit him to prison, or release him. The justice was required to take and record, in writing, the sworn information of the complainant... and any additional witnesses the complainant could provide. In effect, this procedure put some pressure on a complainant to offer prima facie, sworn proof of the guilt of the arrestee contemporaneously with the arrest. ${ }^{154}$

There was no room for the arresting person to release the arrestee without formally beginning prosecution, because doing so would subject

Although the scope of common law misdemeanor arrest authority remains contested, a question that was at the heart of Atwater v. City of Lago Vista, 532 U.S. 318 (2001), the substance of the disagreement matters little for the present purposes.

150. 4 William Blackstone, COMMENTARIES *293 (emphasis added).

151. Davies, Original Fourth Amendment, supra note 147, at 625 ('“'Unlawful' (unjustified) arrests ... exposed the officer to lawful resistance ....").

152. Davies, Fictional Originalism, supra note 147, at 324, 325 (2002) ("Acquittal of the arrested person following a warrantless misdemeanor arrest meant that the arrest was unlawful and an actionable trespass," and "[a] person who made a warrantless misdemeanor arrest that did not comply with the committed-in-the-presence-of, during-the-commission-of, breach-of-the-peace, or similar requirements was exposed to trespass liability for an unlawful arrest regardless of the conviction of the misdemeanant.").

153. Davies, Correcting History, supra note 143, at 57-58 identifies a few potential exceptions: flight of a suspected felon, hue and cry, and temporary arrest authority of night watchmen with respect to night walkers. An arrest of the "dangerously insane" was another exception. See infra notes 209-210 and accompanying text.

154. Davies, Bare-Probable-Cause, supra note 143, at 13 n.39; see also Gerstein v. Pugh, 420 U.S. 103, 114 (1975) ("At common law it was customary, if not obligatory, for an arrested person to be brought before a justice of the peace shortly after arrest."). 
him to liability for illegal arrest. Likewise, there was little room to investigate post-arrest, since proof of guilt was required promptly thereafter. Moreover, other incentives reinforced the imperative to arrest in every permissible instance and to abstain when the arrest could be unlawful: constables were paid in a fee-per-service basis, rather than a salary, which encouraged every arrest that would not result in liability. And private individuals paid fees to initiate prosecutions, which further discouraged false arrests. ${ }^{155}$ In short, the common law of arrest in the Founding era and the Early Republic effectively "enforced" the prosecution principle, rendering unlawful many arrests that were not followed by prosecution, and supported by incentives that discouraged arrests not resulting in conviction.

The law of arrest became more permissive just as American cities were inaugurating professional police forces. ${ }^{156}$ Nonetheless, midnineteenth and early twentieth century cases were explicit about the purposes that justify the arrest power. For example, a North Carolina court explained that arrests are necessary because "[i]t concerns the public that all who commit felonies should be punished," and thus, "provided there be proof that a felony has been committed," "an officer ... may justify the arrest of a suspected person for the purpose of bringing him before a committing magistrate."157 Relying on common law authorities such as Coke, Blackstone, and Hale, courts declared that "if felony is done, and one hath suspicion upon probable matter that another is guilty of it, he may arrest the party so suspected, to the end that he may be brought to justice." $"$ Another court was explicit that the prosecution principle is a legal imperative: some arrests "may be [made] without a warrant, but it is only for the purpose of taking the offender before a Magistrate. He may be taken and detained, until he can be committed to the custody of the law. The arrest is for no other purpose." 159

155. Eric H. Monkkonen, History of Urban Police, 15 CrIME \& JUST. 547, 550-52 (1992) (citing literature).

156. See id. at 553 ("Uniformed police spread across the United States to most cities... between 1850 and 1880."); Davies, Correcting History, supra note 143, at 191 (dating the "creation" of police discretion to the withering of the committed-in-fact requirement and the acceptance of "bare" probable cause).

157. Brockway v. Crawford, 48 N.C. 433, 437-39 (1856).

158. Martin v. Houck, 141 N.C. 317, 322 (1906) (quoting Ashley's Case, 12 Coke, 90); see also Rohan v. Sawin, 59 Mass. 281, 285 (1850) (explaining why peace officers were granted greater arrest authority than ordinary citizens, and stating that this authority is "for the purpose of detaining the party to await further proceedings under a complaint on oath and a warrant thereon.").

159. Long v. State, 12 Ga. 293, 318 (1852). 
Notably, the prosecution principle was treated as a legal imperative even after the rise of urban police created some space for discretion. For instance, in an 1878 Massachusetts case, an action was brought against the town constable, who arrested the plaintiff without a warrant for drunkenness in a public place, but then released him. The constable never made a complaint against the drunk or sought a warrant for his arrest, and the plaintiff then sued for false imprisonment. The court held that an arrest "was only authorized as preliminary to a complaint and judicial proceeding, and that the officer making such arrest was liable to an action for assault and false imprisonment if he omitted to take the party arrested before the proper tribunal and to complain against him for the crime of drunkenness."160 Although the statute invoked by the constable was couched in permissive, discretionary terms, ${ }^{161}$ the court declined to interpret the statute in a way that would "change the purpose of the arrest when made" and grant the officers "a discretion so wide and so liable to abuse." " "[T] detain the person arrested in custody for any purpose other than that of taking him before a magistrate is illegal," as another court held. ${ }^{163}$ Thus, nineteenth and early twentieth century police officers were liable in tort, or even criminally liable, ${ }^{164}$ when they made arrests for purposes other than commencing prosecutions.

160. Phillips v. Fadden, 125 Mass. 198, 200 (1878).

161. Id. at 200-01 ("Whoever is found in a state of intoxication in a public place ... may be apprehended by any ... [peace] officer.... The officer may then make a complaint against him for the crime of drunkenness." (citation omitted)).

162. Id. at 201 ("When the Legislature provides for an arrest by a peace-officer, we must understand that the arrest intended is such as is incident to the service of legal process. The custody is to be temporary only, to continue until the party arrested is in a condition proper for his appearance in court. The provision, that the officer may then make a complaint for the crime of drunkenness, only means that he need not make the complaint until then.").

163. Newhall v. Egan, 28 R.I. 584, 589 (1908) (citing cases); see also Brock v. Stimson, 108 Mass. 520, 522 (1871) ("The statute authorizes the arrest without a warrant, only as a preliminary step towards taking the prisoner before a court"); Caffrey v. Drugan, 144 Mass. 294, 295 (1887) ("It is still the duty of the officer to make complaint after having arrested without a warrant."); Doherty v. Shea, 320 Mass. 173, 175 (1946) ("The person arrested has the right to be brought before the court.").

164. People v. Fick, 89 Cal. 144, 153 (1891) ("[I]f [the appellant] did not make the arrest in good faith, and ... carried [a woman] into Placer county without any intention of taking her before the magistrate issuing the warrant, ... and did not in fact take her before any magistrate, then they must find him guilty [of kidnapping]."). 


\section{The Rise and Recognition of Police Discretion}

Well into the twentieth century, these cases continued to be cited as precedential authority. ${ }^{165}$ By the turn of the century, police forces became well-entrenched in cities, and took on the investigative functions that were previously the province of the judicial magistrates. Arrests made for the purposes of investigation clearly contravened the prosecution principle because "arrest, even on probable cause, [was] not properly a vehicle for the investigation of crime." 166 Spurring police to use arrests even more creatively, modern police were tasked with functions "unexpected by their original creators."167 In addition to investigation and arrests of known offenders, "police took in tramps, returned lost children by the thousands, ... . enforced sanitation laws," and "dispensed forms of welfare in response to the pressing demands of citizens." 168 This expansion in functions brought with it many opportunities to misuse the arrest power. ${ }^{169}$ And by all accounts, police embraced these opportunities, commonly "us[ing] their own judgment about when to arrest and for what purpose."170

For decades, police discretion remained below the radar of courts and legislatures. ${ }^{171}$ As a result, "the great majority of arrests by police officers [we]re illegal under the letter of the law."172 For example, though officers were generally sanctioned by the law for releasing arrestees, the practical pressures to do so became "irresistible:" in an attempt to guard themselves, police made prisoners sign an agreement

165. See, e.g., Doherty v. Shea, 320 Mass. 173, 175 (1946) ("[T]he failure of the officer or someone in his behalf, to make a complaint against [the arrestee] renders the officer liable for false imprisonment." (citing Phillips v. Fadden, 125 Mass. 198, 200-01 (1878))).

166. James E. Hogan \& Joseph M. Snee, The McNabb-Mallory Rule: Its Rise, Rationale and Rescue, 47 GEO. L. J. 1, 23 (1958).

167. Monkkonen, supra note 155 , at 554.

168. Id. at 554-55 (concluding that police virtually became "city servants as well a crimecontrol officers").

169. As Monkkonen notes, the rise of the uniformed police officer (1850s-1880s) also made these more visible to the community, and community members were able to ask them for aid in noncriminal matters. Id. at 551.

170. WALKeR, supra note 132, at 10; Ronald J. Allen, The Police and Substantive Rulemaking: Reconciling Principle and Expediency, 125 U. PA. L. REV. 62, 63 (1976) ("[T]here has been a growing realization that the cop on the beat often exercises discretion in his decision to invoke or not to invoke the criminal process."); see also CULP DAVIS, supra note 132, at 1-3.

171. See Wayne LaFave, The Police and Nonenforcement of the Law-Part I, 1962 WIS. L. REV. 104 (1962).

172. Sam Warner, The Uniform Arrest Act, 28 VA. L. REV. 315, 315 (1941-1942). 
not to sue them. ${ }^{173}$ Among others, LaFave and Kenneth Culp Davis documented arrests of drunks, prostitutes, gamblers and transvestites to control disorder, to punish, and sometimes to provide social services (as in the case of prostitutes, who could be medically examined in custody). ${ }^{174}$ Barrett's study of California arrests in 1960 found that 28.5 percent of all arrested for felonies were released without the filing of formal charges. ${ }^{175}$ Police releases were attributable to a particularly problematic use of arrests "for investigation" or "on suspicion." 176 As the Supreme Court would soon recognize in Terry v. Ohio, the practices amounted to "the wholesale harassment by certain elements of the police community, of which minority groups, particularly Negroes, frequently complain." 177

The "wide gulf between the law and the practices of the police"178 narrowed only slowly in the first few decades of the twentieth century. In the 1930s, the Uniform Arrest Act proposed a limited set of circumstances where a police officer could release a prisoner lawfully, while still cautioning against "indiscriminate release[s]." " And a few legislatures adopted laws to the same effect. ${ }^{180}$ Even in relaxing the legal implications of the prosecution principle, the Uniform Arrest Act reaffirmed its normative force: an "officer ... should not be encouraged to arrest precipitously by being permitted to repent on the way to the station." "181 A few legislatures also followed the Arrest Act in recognizing detentions for questioning to determine whether an arrest should be made, presaging Terry seizures. ${ }^{182}$ But a real recognition of police discretion did not come until the ABF Survey of the

\footnotetext{
173. Id. at 337-38.

174. See LAFAVE, ARrest, supra note 139, at 450-82; Culp DAVIS, supra note 132, at ch. 1.

175. Edward L. Barrett, Jr., Police Practices and the Law_From Arrest to Release or Charge, 50 CALIF. L. REV. 11, 33 (1962).

176. A review of practices of the DC police in 1960-61 found that "in almost every case the person arrested for investigation was searched, and photographed and finger-printed for the police files," in over twenty percent the person was taken from his or another's home, and "approximately fifty-five per cent were held for more than four hours." Yale Kamisar, Report and Recommendations of the Commissioner's Committee on Police Arrests for Investigation, 76 HARV. L. REV. 1502, 1506 (1963).

177. Terry v. Ohio, 392 U.S. 1, 14 (1968); see also CULP DAVIS, supra note 132, at 14-20 (describing arrests made intentionally to harass).

178. Barrett, supra note 175 , at 21 n.53.

179. Warner, supra note 172, at 338.

180. Barrett, supra note 175 , at 24 .

181. Warner, supra note 172 , at 338 .

182. Barrett, supra note 175,24 n.61.
} 
Administration of Criminal Justice in the 1950 s, ${ }^{183}$ with the Supreme Court's reckoning with the same arriving even later.

\section{The Terry Division of Labor}

Terry v. Ohio was key in accommodating the realities of modern policing to the historical prosecution principle. The salient dimensions of the decision are its dispensation with probable cause and the adoption of a lower standard of suspicion for a category of lesser intrusions, and the reliance on constitutional reasonableness. A less conspicuous aspect of the decision was to implicitly reaffirm the prosecution principle. By contrast with the brief seizure and "frisk" in Terry, full-scale arrests, as the Court emphasized, are a "wholly different kind of intrusion upon individual freedom," which "is inevitably accompanied by future interference with the individual's freedom of movement." 184 An arrest "eventuate[s] in a trip to the station house and prosecution for crime," and heralds the "the initial stage of a criminal prosecution ... intended to vindicate society's interest in having its laws obeyed."186 The Court cited LaFave for this proposition, suggesting agreement with his contention about the purposes of arrests. ${ }^{187}$

The Court recognized that seizures short of arrests were necessary precisely because a legitimate need, such as "a perfectly reasonable apprehension of danger[,] may arise long before the officer is possessed of adequate information to justify taking a person into custody for the purpose of prosecuting him for a crime." ${ }^{188}$ The Court chose to recognize a distinct set of seizures to allow the police to serve this legitimate need - by implication preserving the traditional prosecutorial purposes of full arrests. The decision created a division of labor within the universe of personal seizures, where "the interests each [kind of intrusion] is designed to serve are .. . quite different."189 This division of labor meant that police may not pursue the interests that justify only

183. Allen, supra note 170, at 63; WALKER, supra note 132, at 6 ("[P]rior to the late 1950 s, [even] the leading experts in the field barely acknowledged [the] existence [of discretion].").

184. Terry v. Ohio, 392 U.S. 1, 26 (1968) (emphasis added).

185. Id. at 16 (emphasis added).

186. Id. at 26 (emphasis added).

187. Id. at $26 \mathrm{n} .22$; in pages cited by the Court, LaFave suggests, inter alia, that arresting "for purposes other than prosecution," such as the "administration of certain social services" is of "doubtful propriety." LAFAVE, ARREST, supra note 139, at 12.

188. Id. at $26-27$.

189. Id. at 26 . 
temporary seizures by means "that approach the conditions of arrest."190 In Justice Brennan's words, "[a] brief detention is usually sufficient as a practical matter to accomplish all legitimate law enforcement objectives with respect to individuals whom the police do not have probable cause to arrest."191

Terry represented both a concession and a much needed accommodation to the realities of modern policing. It allowed the police the space to "enforce" laws for which prosecution is not deemed necessary - whether it is because police do not think the administrative costs of a full arrest are worth it or because they believe that a temporary seizure will in fact prevent or disrupt criminal conduct and serve public order. Indeed, merely disrupting crimes without prosecution characterized police strategies with regard to vice, public order offenses such as public drinking, or gang-related ordinances at the time, and the Terry division of labor accommodated these approaches. ${ }^{192}$

Of course, crime prevention and disruption are not the only common non-prosecutorial goals of modern policing. Police acquired new functions outside investigation and criminal law enforcement-notably community caretaking and peacekeeping - which are now broadly accepted institutional purposes of the police. ${ }^{193}$ One might suppose that these new, patently non-prosecutorial functions of modern policing signaled a retrenchment from the prosecution principle. This would be a hasty conclusion. The acceptance of these functions in general does not imply that it has become legitimate to use arrests for these purposes. Indeed, judicial treatment of the community caretaking functions suggests that unless explicitly authorized by statute, arrests for caretaking purposes are the exception, not the norm. State and federal courts are divided on the scope of the community caretaking exception

190. Florida v. Royer, 460 U.S. 491, 499 (1983).

191. Kolender v. Lawson, 461 U.S. 352, 363 n.2 (1983) (J. Brennan, concurring) (emphasis added).

192. See, e.g., Wayne R. LaFave, "Street Encounters" and the Constitution: Terry, Sibron, Peters, and Beyond, 67 MiCH. L. REV. 39, 61-62 (1968) (detailing common uses of Terry stops).

193. See, e.g., Cady v. Dombrowski, 413 U.S. 433, 441 (1973) ("Local police officers ... engage in what, for want of a better term, may be described as community caretaking functions, totally divorced from the detection, investigation, or acquisition of evidence relating to the violation of a criminal statute."); United States v. Rideau, 949 F.2d 718, 720 (5th Cir. 1991), opinion rev'd on reh'g on other grounds, 969 F.2d 1572 (5th Cir. 1992) (officers must "“aid individuals who are in danger of physical harm,' 'assist those who cannot care for themselves,' and 'provide other services on an emergency basis"” (quoting I ABA Standards for Criminal Justice, Standard $\S 1-2.2$ at 31-32 (2d ed. 1980))). 
from the warrant and probable cause requirements. ${ }^{194}$ However, when courts do uphold seizures of persons for community caretaking purposes without relying on a legislative grant of authority, they anchor their opinions in Terry, implicitly incorporating its division of labor between arrests and lesser seizures.

In the course of community caretaking, courts recognize, "a police officer may have occasion to seize a person ... in order to ensure the safety of the public and/or the individual, regardless of any suspected criminal activity." 195 If courts readily held that community caretaking could serve as the primary justification for a full custodial arrest, in the absence of any statutory authority that would signal a significant erosion of the prosecution principle. However, seizures of persons upheld by courts for this purpose have been brief in duration, comparable to the investigative stop addressed in Terry. ${ }^{196}$ Although some authorities suggest that community caretaking may justify arrests, ${ }^{197}$ a closer examination reveals that cases purportedly justifying arrests on the basis of community caretaking are in fact dealing with temporary seizures. ${ }^{198}$ For example, a seizure of a juvenile found in an isolated area at night "for the brief time it took the officers to call his mother," 199 a brief stop of a "man... standing in the middle of the road and possibly intoxicated," $" 200$ a "brief" detention of a potentially intoxicated driver to

194. See, e.g., Sutterfield v. City of Milwaukee, 751 F.3d 542, 556 (7th Cir. 2014) (courts are "divided on the question of whether the community caretaker exception applies outside of the automobile context").

195. United States v. King, 990 F.2d 1552, 1560 (10th Cir. 1993).

196. The primary distinction between a brief seizure as in Terry and a full arrest is temporal duration, although the "scope" of the intrusion may also matter. See LAFAVE, supra note 16, at $\S$ 9.2(f).

197. See e.g., Goldsmith v. Snohomish Cnty., 558 F. Supp. 2d 1140, 1152 (W.D. Wash. 2008) (claiming that some circuits "have held that the 'community caretaking' function applies to arrests as well as searches").

198. E.g., the cases cited in Goldsmith v. Snohomish Cnty., in support for this claim all dealt with temporary seizures: Rideau, 949 F.2d at 719 (at issue is a "brief detention"); Winters v. Adams, 254 F.3d 758, 766 (8th Cir. 2001) (at issue is the authority to "briefly detain"); King, 990 F.2d at 1561 (at issue is whether defendant could be "briefly detained"). In Goldsmith itself, although the court described the seizure as an "arrest," it was explicit that at issue was a "brief" arrest "for the sole purpose of enabling paramedics to render necessary medical aid" to the arrestee. $558 \mathrm{~F}$. Supp. $2 \mathrm{~d}$ at 1152 . Moreover, the court misleadingly defined an arrest as a generic seizure, which applies to both a Terry-level seizure and a full arrest, without distinguishing the two. $558 \mathrm{~F}$. Supp. $2 \mathrm{~d}$ at 1151 ("An arrest occurs when, considering all the circumstances, a reasonable person would not feel free to leave.").

199. State v. Acrey, 148 Wash. 2d 738, 753 (2003) (quoting State v. Acrey, 110 Wash. App. 796-70 (Wash. Ct. App. 2002)).

200. Rideau, 949 F.2d at 720 . 
investigate his competence to drive $\mathrm{e}^{201}$ or a driver presenting another hazard to advise him thereof, ${ }^{202}$ are examples of the lawful exercises of the community caretaking.

Significantly, courts are explicit that the police power to seize individuals for "non-investigatory" purposes is rooted in the rationale of Terry and reasonableness analysis. Although it dealt with suspicion of criminal activity, courts have read the decision as extending to "“[e]ncounters [that] are initiated by the police for a wide variety of purposes." 203 Absence of criminal suspicion, as one court explains, "does not render such a seizure unreasonable per se as Terry only requires 'specific and articulable facts which ... reasonably warrant [an] intrusion' into the individual's liberty." "204 To ascertain whether a seizure is reasonable, the court resorts to "essentially the Terry test, but applied in a community caretaker setting.", 205 As in Terry, "the governmental interest in ... ensuring the public safety," for example, "is sufficiently important to outweigh the relatively minor intrusions ...."206 Accordingly, whether at issue is "a Terry or [a] community caretaking stop," it "justifies "no more than a brief [seizure and] interrogation.",207 By contrast, there is no room for reasonableness balancing with respect

201. Winters, 254 F.3d at $762,766$.

202. King, 990 F.2d at 1560-61 (holding that the officer "was justified in approaching Defendants' car and could have briefly detained Defendants in order to inform [him] of the hazardous conditions and to advise him to cease honking"); Ullom v. Miller, 227 W. Va. 1, 13 (2010) (trooper's "initial encounter with Ms. Ullom was properly admissible pursuant herein to the 'community caretaker doctrine' exception... [until he] was assured that Ms. Ullom was not in actual need of emergency aid, [at which point] his caretaking duties were over and any further detention ... would have constituted an unreasonable seizure").

203. Rideau, 969 F.2d at 1574 (quoting Terry, 392 U.S. at 13); see also Winters, 254 F.3d at 763-64 ("The Court simply cannot conclude that the strictures of Terry and its progeny compel" its limitation to suspicion of criminal wrongdoing).

204. King, 990 F.2d at 1560-61 ("Whether the seizure of a person by a police officer acting in his or her noninvestigatory capacity is reasonable depends on whether it is based on specific articulable facts and requires a reviewing court to balance the governmental interest... and the individual's interest in being free from arbitrary government interference" (citing United States v. Brignoni-Ponce, 422 U.S. 873, 878 (1975); Terry, 392 U.S. at 21)); see also Debra Livingston, Police, Community Caretaking, and the Fourth Amendment, 1998 U. CHI. LEGAL F. 261, 300 (1998) ("The Court's decision in Cady... provides support for using a reasonableness approach in assessing community caretaking intrusions.").

205. State v. Anderson, 417 N.W.2d 411, 414 (Wis. Ct. App. 1987).

206. King, 990 F.2d at 1560-61. Some of the detentions upheld as an exercise of community caretaking were likely longer than the brief detention in Terry; however, as with investigative detentions, although these "must be temporary and last no longer than is necessary," their duration and scope "will vary to some extent with the particular facts and circumstances of each case." Florida v. Royer, 460 U.S. 491, 500 (1983).

207. Shields v. Tracy, No. CIVS031614DFL-PAN, 2005 WL 1490300, at *5 (E.D. Cal. June 21, 2005) (citing United States v. Robertson, 833 F.2d 777, 780 (9th Cir. 1987)). 
to custodial arrests, for which "the requisite 'balancing' has been performed in centuries of precedent and is embodied in ... probable cause." 208

For exceptional situations - namely, to prevent suicide or restrain certain mentally ill individuals - custodial arrests, or detentions tantamount to arrests, have been historically recognized as appropriate. ${ }^{209}$ However, this should not be taken as a sign of abandonment of the prosecution principle in the face of uniquely modern realities. The authority to arrest one "who is so insane as to be dangerous to himself or others," without judicial authorization, is as old as the authority to arrest felons. ${ }^{210}$ Moreover, arrests of the mentally ill or suicidal individuals have become regulated by statute. ${ }^{211}$ Courts that uphold arrests for these purposes are recognizing an affirmative grant of authority by the legislature, rather than rejecting the prosecution principle. ${ }^{212}$

In sum, unless otherwise authorized by statute, ${ }^{213}$ courts have tended to view community caretaking and other non-investigative purposes as on the Terry side of the division of labor, justifying only "lesser government intrusions into an individual's liberty."214

\section{Prosecution Principle as Guide for Discretion}

Terry and its extended progeny deal with the explicit, official purposes advanced by the police to justify seizures. But the normative force of the prosecution principle has also led courts to disapprove of

208. Dunaway v. New York, 442 U.S. 200, 214 (1979).

209. Monday v. Oullette, 118 F.3d 1099, 1102 (6th Cir. 1997) (citing cases across circuits to the same effect).

210. D. A. Cox, Annotation, Right, Without Judicial Proceeding, to Arrest and Detain One Who Is, or Is Suspected of Being, Mentally Deranged, 92 A.L.R.2d 570, at I.2. (Originally published in 1963).

211. Id. at III.9. ("Many jurisdictions have adopted statutes dealing in varying degrees with the arrest and confinement of the insane and mentally incompetent.").

212. See, e.g., Monday, 118 F.3d at 1103 (arrest to prevent suicide did not violate the Fourth Amendment or the state's law providing for such seizures).

213. Some courts decline to extend the community caretaking justification beyond the automobile context recognized in Cady without an affirmative statutory recognition of that authority. E.g., State v. Bridewell, 759 P.2d 1054, 1059 (Or. 1988) ("There is no generic "community caretaking function.' Whether law enforcement officers have specific functions is a matter of statutory law.”); Sivik v. Driver \& Motor Vehicle Servs. Div., 231 P.3d 1177, 1179 (Or. Ct. App. 2010) ("The community caretaking statute is not an exception to the warrant requirement. It is the statutory expression of the well-settled precept that the actions of law enforcement officers, like all other government actors' actions, must be traceable to some grant of authority from a politically accountable body." (citations omitted)).

214. United States v. King, 990 F.2d 1552, 1557 (10th Cir. 1993). 
ulterior motives - that is, hidden purposes police harbor when they make arrests that are objectively backed by probable cause. The aspiration of the prosecution principle in this regard can be understood as the minimization of "pretextual" arrests. ${ }^{215}$

\section{The Problem of Pretextual Arrests}

Several jurisprudential features reflect the special status of arrests in the arsenal of law enforcement. One can consent to a search, which allows the police access to otherwise protected interests without requisite legal justification, implying that police can search for a broader set of purposes than a well-founded expectation of evidence. ${ }^{216}$ One can also consent to a temporary seizure of oneself, which transforms a seizure into a consensual encounter that requires no suspicion. But one cannot consent to one's own formal custodial arrest without probable cause. One could, of course, consent to come to the station; ${ }^{217}$ ultimately, however, if police wish to effectuate a formal arrest, consent will not make it lawful without probable cause. Likewise, the interests implicated by searches, seizures of property, and even brief seizures of persons, are subject to intrusion as a result of third-party consent. ${ }^{218}$ By contrast, a third party's consent does not vitiate the requirement that an arrest be backed by probable cause. ${ }^{219}$

215. Pretext has been variously defined by courts and commentators. Sometimes, it is defined in terms of a specific subset of ulterior motives: "[A] pretextual arrest occurs when the police employ an arrest based on probable cause as a device to investigate or search for evidence of an unrelated offense for which probable cause is lacking." United States v. Trigg, 878 F.2d 1037, 1039 (7th Cir. 1989) (emphasis added), abrogated in part by Virginia v. Moore, 553 U.S. 164 (2008). Other times, it is defined in terms of any ulterior motives: "[A] so-called 'pretext' arrest" occurs when "an officer has probable cause to make an arrest because the officer has observed a violation, albeit a minor one for which the officer probably would not have made an arrest had there not existed some motivation beyond the observed offense." United States v. Scopo, 19 F.3d 777, 785 (2d Cir. 1994) (Newman, J., concurring) (emphasis added). For the purposes of this discussion, I adopt the latter, broader conception of pretext.

216. See generally WAyne R. LAFAVE et AL., 2 Criminal Procedure $\S 3.10$ (a) (3d ed. 2000).

217. E.g., Vance v. State, 2011 Ark. 243 (2011) (appellant was not seized because his visit to the station was found to be voluntarily or consensual).

218. See generally LAFAVE ET AL., supra note 216, at $\S 3.10$ (d)

219. For example, in United States v. Woodrum, 202 F.3d 1, 10 (1st Cir. 2000), the court held that a "passenger may be briefly detained" as a result of the taxi driver's consent to the stop. The court emphasized that the stop was reasonable because it was a "modest intrusion on passengers' liberty" and cautioned that "this does not mean that a taxicab passenger assumes the risk of every type of seizure." Id. at 11-12. 
These features seem to require a closer relationship between the "hypothecated" 220 reasons that justify arrests and the actual purposes pursued by police. That means that pretext is a bigger normative problem for arrests than for other police activities of constitutional significance. ${ }^{21}$ Thus, a variety of doctrinal vehicles have historically been deployed by the courts in attempts to constrain pretextual arrests. The vagueness doctrine and the now mostly abandoned "pretext doctrine" under the Fourth Amendment constituted such attempts. This jurisprudence is familiar ground; here I aim only to bring out the ways in which it evoked the prosecution principle as the standard relative to which police conduct is assessed.

The Supreme Court's invalidation on vagueness grounds of laws criminalizing vagrancy, loitering, and breaches of peace since the 1970s revealed the Court's disapproval of pretextual arrests. ${ }^{222}$ Vague laws are constitutionally objectionable in part for notice reasons, and in part on account of unfettered enforcement discretion. ${ }^{223}$ As Debra Livingston recounts, critics cited evidence that vagrancy statutes were used "to detain classes of people during conventions [and] elections ...; to break strikes; to 'round up' ostensible suspects ... when a crime had been committed," 224 as well as "against participants in peaceful sit-ins and civil rights demonstrations in the South." 25 And vague laws enabled police to harass people selectively based on race and class. ${ }^{226}$

220. Scott v. United States, 436 U.S. 128, 138 (1978).

221. With the possible exception of entry into the home, which courts also regard as requiring heightened protection. See, e.g., Sutterfield v. City of Milwaukee, 751 F.3d 542, 556 (7th Cir. 2014) (citing circuits which have refused to extend the community caretaking exception to searches of the home).

222. The challenges to these broad and indefinite prohibitions were partly prompted by scholarly criticism of the discriminatory misuses of discretion enabled by the laws. See Debra Livingston, Police Discretion and the Quality of Life in Public Places: Courts, Communities, and the New Policing, 97 Colum. L. REv. 551, 557-58 (1997).

223. Kolender v. Lawson, 461 U.S. 352, 357-58 (1983) ("Although the doctrine focuses both on actual notice to citizens and arbitrary enforcement, we have recognized recently that the more important aspect... [is] 'the requirement that a legislature establish minimal guidelines to govern law enforcement." (citation omitted)). For an account of the link between vagueness and discriminatory use of discretion, see John Calvin Jeffries, Jr., Legality, Vagueness, and the Construction of Penal Statutes, 71 VA. L. REV. 189, 214-18 (1985).

224. Livingston, supra note 222, at 596.

225. Id. at 598 .

226. See, e.g., William O. Douglas, Vagrancy and Arrest on Suspicion, 70 YALE L.J. 1, 13 (1960) ("The persons arrested on 'suspicion' are not the sons of bankers, industrialists, lawyers, or other professional people. They, like the people accused of vagrancy, come from other strata of society, or from minority groups who are not sufficiently vocal to protect themselves."). 
In Papachristou ${ }^{227}$ and Kolender, ${ }^{228}$ the Court echoed these concerns. Justice Douglas's opinion in Papachristou contrasted American arrest authority with Russia's, writing that arrests "on suspicion," "for investigation," or on basis of "past" or "future criminality" are "foreign to our system." 229 That included arrests made because the police suspect a person of a particular other crime; arrests made to pursue "general law enforcement objectives of investigating and preventing unspecified crimes"; ${ }^{230}$ and arrests made to nip crime "in the bud."231 "States may not authorize the arrest and criminal prosecution of an individual" under vague statutes for the ulterior purposes of "facilitat[ing] the general law enforcement objectives of investigating and preventing unspecified crimes.",232 Moreover, vague laws "encourage arbitrary and discriminatory enforcement." $" 233$ Selectively focusing the power of arrest on "particular groups deemed to merit their displeasure"234 or pursuing "personal predilections" 235 is presented by the Court as a clear misuse of the discretionary arrest power. ${ }^{236}$

Although the Court does not use the term, an objectionable feature of such arrests is their pretextual nature. In Justice Douglas's words, "[a] vagrancy prosecution may be merely the cloak for a conviction which could not be obtained on the real but undisclosed grounds for the

227. Papachristou v. City of Jacksonville, 405 U.S. 156, 158 (1972) (invalidating a Jacksonville ordinance criminalizing the status of "rogues and vagabonds," "common drunkards," "pilferers," "common railers and brawlers," and "habitual loafers," among many others).

228. Kolender involved a challenge to a statute that "requires persons who loiter or wander on the streets to provide a 'credible and reliable' identification and to account for their presence when requested by a peace officer under circumstances that would justify a stop under the standards of Terry v. Ohio." 461 U.S. at 352.

229. Papachristou, 405 U.S. at 168-69.

230. Kolender, 461 U.S. at 362 (Brennan, J., concurring).

231. Papachristou, 405 U.S. at 171.

232. Kolender, 461 U.S. at 362 (Brennan, J., concurring).

233. Id. at 357; see also Coates v. City of Cincinnati, 402 U.S. 611, 611, 616 (1971) (invalidating a law making it criminal for "three or more persons to assemble" and "conduct themselves in a manner annoying to persons passing by" because it is "an obvious invitation to discriminatory enforcement against those whose association together is "annoying' because their ideas, their lifestyle, or their physical appearance is resented by the majority of their fellow citizens.").

234. Kolender, 461 U.S. at 360.

235. Id. at 357-60 (citations omitted).

236. See also Winters v. New York, 333 U.S. 507, 540 (1948) (Frankfurter, J., dissenting) (identifying the problem with the vagrancy laws in terms of the ability of the police to focus on "men... who are vaguely undesirable in the[ir] eyes," but not "chargeable with any particular offense."). 
arrest." 237 The pretext afforded by vagrancy laws happens to be particularly flimsy and slippery due to the lack of "ascertainable standards of guilt." ${ }^{238}$ However, one must suspect strongly that the "real," illegitimate grounds for arrests surveyed by the Court would be objectionable even if the pretext were stronger, such as that provided by a non-vague law. Indeed, according to scholars such as Livingston, "the Court's judgment in Papachristou was not about vagueness at all," but was primarily an indictment of the purposes to which police put the vagrancy law. ${ }^{239}$ And, as it turns out, the unfettered-discretion-based objections to vague laws apply to specific laws as well: as several scholars have argued, police can and do act for all the same improper reasons when the criminal laws are specific, but broad and overlapping. $^{240}$

\section{The Fourth Amendment and the Prosecution Principle}

If the vagueness cases convey disapproval of covert ulterior motives, one might think that modern Fourth Amendment law has embraced such motives and abandoned the prosecution principle. ${ }^{241}$ Over the past two decades or so, it became increasingly clear that arbitrariness and improper motives will rarely run afoul of the Fourth Amendment. In Whren, the Supreme Court confirmed that an "officer's motive" does not "invalidate[] objectively justifiable behavior under the Fourth Amendment." ${ }^{242}$ In Atwater, the Court upheld police authority to arrest

237. Papachristou v. City of Jacksonville, 405 U.S. 156, 169-70 (1972).

238. Id. at 165 .

239. Livingston, supra note 222, at 604-05; see also David Thacher, Order Maintenance Policing, in The OXford HandBook OF POLICE AND POlicing 122, 127 (Michael Reisig and Robert Kane, eds., 2014) (arguing that "one motivation" for striking down vagrancy laws "was precisely to rein in the pretextual use of order maintenance authority.").

240. E.g., William J. Stuntz, Unequal Justice, 121 HARV. L. REV. 1969, 1978 (2008) ("Legislators can define broad crimes as specifically as narrow ones, and thereby create as much enforcement discretion as they wish without violating the void-for-vagueness doctrine"); Thacher, supra note 239, at 123 ("[P]retextual uses of public order law continue today, as many cities encourage police to enforce public drinking and loitering rules not out of any intrinsic concern about the behaviors they regulate but to give police more opportunity to search for guns and fugitives.").

241. See, e.g., Tracey Maclin, What Can Fourth Amendment Doctrine Learn from Vagueness Doctrine?, 3 U. PA. J. CONST. L. 398, 401 (2001) (comparing vagueness and Fourth Amendment jurisprudence, and concluding that "the Court is clearly of two minds regarding the Constitution's tolerance for police discretion").

242. Whren v. United States, 517 U.S. 806, 812 (1996). Even before the Supreme Court made explicit that Whren applies to arrests, as well as a traffic stop in Arkansas v. Sullivan, 532 U.S. 769 (2001), federal courts have understood it to apply broadly. See, e.g., United States v. Clarke, 110 F.3d 612, 613-14 (8th Cir. 1997) ("Although Whren specifically concerned a traffic stop, we believe 
for any criminal offense, no matter how minor. ${ }^{243}$ And in Devenpeck $v$. Alford, the Court rejected the rule that "the offense establishing probable cause must be 'closely related' to, and based on the same conduct as, the offense identified by the arresting officer at the time of arrest." 244 These cases make it plain that whatever vitality the prosecution principle retains, its violation has no Fourth Amendment consequences.

In advance of these cases however, lower courts implicitly invoked the aspiration of the prosecution principle. Courts "plumb[ed] the minds" of police for "impure plots," 245 identifying circumstances when "improper,"246 "impermissible," ${ }^{247}$ and "illegitimate motives," ${ }^{248}$ or "invalid purpose[s]" or "subterfuge"249 vitiate an otherwise lawful action. Courts that adopted some pretext doctrine concluded that "[a]n arrest ostensibly for one purpose but in reality for the primary purpose of furthering an ulterior goal is unreasonable." ${ }^{250}$ Accordingly, courts sought to craft standards to weed out the arrests most influenced by these ulterior considerations. Most commonly, police were pursuing investigative aims relating to crimes other than those that justified the seizure, including hunting for evidence, ${ }^{251}$ seeking to question the suspect, ${ }^{252}$ or acting on a vague suspicion of criminality. ${ }^{253}$ Courts have disapproved of pretextual seizures executed to identify immigration violators. ${ }^{254}$ And courts have described a variety of considerations as improper: relying on race, ethnicity or a race-based profile, ${ }^{255}$ focusing

\footnotetext{
that its principle is applicable to all police activities for which probable cause is required."); see also Scott v. United States, 436 U.S. 128 (1978); United States v. Robinson, 414 U.S. 218, 228 (1973).

243. Atwater v. City of Lago Vista, 532 U.S. 318, 354 (2001).

244. Devenpeck v. Alford, 543 U.S. 146, 153 (2004).

245. Massachusetts v. Painten, 389 U.S. 560, 565 (1968).

246. See, e.g., United States v. Smith, 799 F.2d 704, 708-09 (11th Cir. 1986); Marquart v. Comm'r. Internal Revenue, No. 99-70046, 2000 U.S. App. LEXIS 9955, at *3-4 (9th Cir. May 9, 2000); State v. Olson, 482 N.W.2d 212, 214 (Minn. 1992).

247. United States v. Uriostegui, 420 F. Supp. 2d 1260, 1262 (M.D. Ala. 2006).

248. See, e.g., People v. Hill, 929 P.2d 735, 740 (Col. 1996).

249. Taglavore v. United States, 291 F.2d 262, 266 (9th Cir. 1961).

250. Warren v. City of Lincoln, Neb., 816 F.2d 1254, 1257-58 (8th Cir.1987), on reh'g, 864 F.2d 1436 (8th Cir. 1989).

251. See United States v. Smith, 802 F.2d 1119, 1124 (9th Cir. 1986) (citing Taglavore, 291 F.2d at 265); United States v. Keller, 499 F. Supp. 415, 417 (N.D. Ill. 1980).

252. Warren, 816 F.2d at 1257; United States v. Valdez, 931 F.2d 1448, 1451 (11th Cir. 1991).

253. See, e.g., United States v. Guzman, 864 F.2d 1512, 1515 (10th Cir. 1988), overruled by United States v. Botero-Ospina, 71 F.3d 783 (10th Cir. 1995); United States v. Miller, 821 F.2d 546 (11th Cir. 1987).

254. E.g., United States v. Cruz, 581 F.2d 535, 539, 541 (5th Cir. 1978), overruled by United States v. Causey, 834 F.2d 1179 (5th Cir. 1987).

255. United States v. Reeves, 798 F. Supp. 1459, 1463-64 (E.D. Wash. 1992), aff'd, 6 F.3d 660
} 
on generally "suspicious" people, people with an "unorthodox appearance," or "out-of-state license plates." ${ }^{256}$ All these cases convey a clear sense that courts disapproved of arrests on bases unrelated to the interest in charging arrestees for the behavior that provided probable cause. And while courts do not always treat arrests as different from lesser seizures, a few courts have suggested that the case for constraining pretextual action is more compelling for arrests than for lesser intrusions. $^{257}$

Likewise, pre-Devenpeck cases explained the need for the "related offense" limitation on valid arrests to discourage "sham arrests" ${ }^{258}$ made on the same improper grounds. Allowing officers to retrospectively find probable cause would "permit an arrest that was a sham or fraud at the outset, really unrelated to the crime for which probable cause to arrest was actually present to be retroactively validated." 259

Mixed motives are surely the rule, rather than the exception. In view of this, courts have sought only to mitigate, rather than wholly root out, the influence of improper motives. Thus, courts have targeted those instances where improper reasons dominated over proper ones: where, for example, the improper motivation was "primary purpose," 260 or instances where the arrest would not be made "but for" the improper motivation. ${ }^{261}$ In other words, the arrest was not a misuse of discretion

(9th Cir. 1993); State v. Lopez, 831 P.2d 1040, 1046 (Utah Ct. App. 1992), aff'd in part and vacated in part, 873 P.2d 1127 (Utah 1994); State v. Arroyo, 796 P.2d 684, 688 n.3 (Utah 1990).

256. E.g., State v. Lopez, 831 P.2d 1040, 1046 (Utah Ct. App. 1992); see also United States v. Scopo, 19 F.3d 777, 785-86 (2d Cir. 1994) (Newman, J., concurring) (declining to adopt a robust pretext doctrine, but noting that using pretext to "harass members of groups" on the basis of "race or ethnic origin, or simply appearances that some police officers do not like, such as young men with long hair, heavy jewelry, and flashy clothing" is "impermissible").

257. See, e.g., State v. Sullivan, 348 Ark. 647, 652 n.1 (2002) ("Our cases have not equated pretextual stops with pretextual arrests due to the different level of police intrusion involved.... The intrusiveness of an arrest warrants inquiry into an officer's subjective intentions."); Fertig v. State, 146 P.3d 492, 501 (Wyo. 2006) (accepting Whren for purposes of traffic stops, but noting "a significant distinction between investigative detentions and arrests").

258. Biddle v. Martin, 992 F.2d 673, 676-77 (7th Cir. 1993) ("[The related offense rule] strike[s] a balance which allows the arresting officer to choose which crime she will charge without having to charge every single offense sustainable on the facts, and yet does not 'open [ ] the door to the 'extrapolation' of offenses in an effort to justify a sham arrest." (citation omitted)).

259. United States v. Atkinson, 450 F.2d 835, 838 (5th Cir. 1971).

260. United States v. Reeves, 798 F. Supp. 1459, 1464 (E.D. Wash. 1992), aff'd, 6 F.3d 660 (9th Cir. 1993); see also United States v. Smith, 802 F.2d 1119, 1124 (9th Cir. 1986) ("whether an arrest is a mere pretext to search turns on the motivation or primary purpose of the arresting officers").

261. E.g., State v. Holmes, 256 So. 2d 32, 34 (Fla. Dist. Ct. App. 1971), opinion adopted, 273 So. $2 \mathrm{~d} 753$ (Fla. 1972) ("The real evil . . is not that the arrest is a pretext for the search, but that the arrest is one which would not have been made but for the motive of the arresting officer."); Diggs v. State, 345 So. 2d 815 (Fla. App. 1977) (question is "whether the arrest was one which would not 
insofar as it is made primarily for the right reasons. Significantly, even courts that upheld actions taken in part for some ulterior motive did not go so far as to actually justify police actions as a normative matter. For example, one court adopting a Whren-like objective approach explained that "an arrest . . . is lawful even if the officer making the arrest . . . based his or her action on the wrong ground or had an improper motive."262 Judges were not willing to concede, in other words, that every lawful arrest represented a proper use of discretion.

The Whren and Atwater decisions were met with a storm of criticism. $^{263}$ Some scholars argue that these decisions are bad law. ${ }^{264}$ The critics may well have the better argument. But there is little reason to think that the Supreme Court discarded the normative underpinnings of the principles it rejected as a doctrinal matter. This line of cases cannot be fairly read to say that it is a matter of indifference how the discretionary authority to arrest is exercised.

The Supreme Court's decisions must be evaluated against a background assumption that there is a difference between "the abstract propriety of the police conduct" ${ }^{265}$ and the propriety of applying a particular constitutionally-based remedy. Even as these cases affirmed broad police discretion, they conveyed disapproval of the seizures at issue there. The Court described the arrest in Atwater as "foolish," a "pointless indignity," and "gratuitous humiliation[] imposed by a police officer who was (at best) exercising extremely poor judgment."

have been made but for some other [ulterior] motive of the arresting officer."); United States v. Smith, 799 F.2d 704, 710 (11th Cir. 1986) (a seizure "was unreasonable not because the officer secretly hoped to find evidence of a greater offense, but because it was clear that an officer would have been uninterested in pursuing the lesser offense absent that hope.").

262. State v. Olson, 482 N.W.2d 212, 214 (Minn. 1992) (citation omitted); see also United States v. Roberson, 6 F.3d 1088, 1092 (5th Cir. 1993) ("while we do not applaud what appears to be a common practice of some law enforcement officers to use technical violations as a cover for exploring for more serious violations, we may look no further than the court's finding that Trooper Washington had a legitimate basis for stopping the van. We thus must conclude that the stop did not violate the fourth amendment.").

263. See, e.g., Harris, supra note 37, at 549; Maclin, supra note 241.

264. Critics argue that at least for subsets of arrests, probable cause itself is an insufficient constraint against the abuse of authority. See Joshua Bowers, Probable Cause, Constitutional Reasonableness, and the Unrecognized Point of a "Pointless Indignity", 66 STAN. L. REV. 987, 992 (2014) (arrests ought to be reasonable in addition to backed by probable cause); Sekhon, supra note 38 (probable cause insufficient for crimes subject to "proactive policing"); Barbara C. Salken, The General Warrant of the Twentieth Century? A Fourth Amendment Solution to Unchecked Discretion to Arrest for Traffic Offenses, 62 TEMP. L. REV. 221, 224 (1989) (probable cause insufficient for traffic offenses).

265. Terry v. Ohio, 392 U.S. 1, 12 (1968).

266. Atwater v. City of Lago Vista, 532 U.S. 318, 346-47 (2001). 
the court acknowledges in Whren that even intentional enforcement on the basis of race would fall outside the Fourth Amendment's prohibitions. ${ }^{267}$ In Devenpeck, the Court does not deny that its holding protects arrests made by officers for "the wrong reason," 268 but claims that the contrary rule would not reduce the incidence of such "sham arrests." "269 As three Justices would have had the Court hold decades earlier, "we might wish that policemen would not act with impure plots in mind," but the presence of such plots is not "a sufficient basis for excluding [evidence], in the supposed service of the Fourth Amendment. ..."270 These are cases where practical considerations of efficacy and courts' limited capacity for discerning police motives ${ }^{271}$ trump the normative pull of the prosecution principle. ${ }^{272}$

Indeed, after Whren, many courts describe that case's holding as divorcing the illegitimacy of actual motives from legality, explaining that they "may not inquire into whether the officer's behavior had improper motives." "273 What they do not say is that any motive is normatively

267. Whren v. United States, 517 U.S. 806, 813 (1996) ("We of course agree with petitioners that the Constitution prohibits selective enforcement of the law based on considerations such as race. But the constitutional basis for objecting to intentionally discriminatory application of laws is the Equal Protection Clause, not the Fourth Amendment.").

268. Devenpeck v. Alford, 543 U.S. 146, 154 (2004).

269. Id. at 155 .

270. Massachusetts v. Painten, 389 U.S. 560, 565 (1968).

271. Sorting among the multitude of mixed motives behind police actions is not a task to be undertaken lightly. See, e.g., United States v. Guzman, 864 F.2d 1512, 1516 (10th Cir. 1988) (the concern about "unfettered police discretion" has to be balanced against the problem that "[a]n examination of a police officer's subjective intent in individual cases would unwisely involve the courts in unproductive inquiries... [since] courts cannot with any degree of regularity determine when there existed an improper motive that influenced the police conduct."'). The Devenpeck Court rejected the related offense limitation on another practical ground: it would not ensure that "officers will cease making sham arrests on the hope that such arrests will later be validated, but rather that officers will cease providing reasons for arrest" or "would simply give every reason for which probable cause could conceivably exist." 543 U.S. at 155.

272. Even as a proponent of the prosecution principle, LaFave observed that the fact of police arrests "for purposes other than the sole legitimate objective" does not mean that the answer is "to use the exclusionary rule as a blunderbuss." LaFave, supra note 192, at 62; see also Thomas R. Folk, The Case for Constitutional Constraints Upon the Power to Make Full Custody Arrests, 48 U. CIN. L. REV. 321, 330 (1979) ("[O]ne approach to th[e] [pretext] problem is to attack it head on ... [and] exclude evidence upon a showing that an arrest was only 'a pretext to search for evidence.' Given the difficulty of determining police motivation, however, the effectiveness of this solution is doubtful.").

273. See, e.g., United States v. Hudson, 100 F.3d 1409, 1415-16 (9th Cir. 1996) (Whren precluded inquiry "into whether the officer's behavior had improper motives"); Artiles v. Vitanza, No. 06-5427 (KSH), 2009 WL 2426259, at *12 (D.N.J. Aug. 6, 2009) (same); People v. Hill, 929 P.2d 735, 740 (Col. 1996) (same); see also Estate of Smith v. Marasco, 318 F.3d 497, 514 (3d Cir. 2003) ("Improper motive, however, is irrelevant to the question whether the objective facts available to the officers."). 
acceptable so long as there is an objective legally sufficient justification. Courts are occasionally explicit that adhering to Whren leaves police abuse of its authority without redress. In a case where an officer was almost certainly motivated by the desire to verify a driver's immigration status, the court stated that when "an officer's suspicion... is raised solely as a result of a driver's ethnicity or race ... Whren could enlist the judiciary as an accomplice... to race or ethnicity-based police actions... [which] would pose a serious challenge to our nation's claimed commitment to a blind, non-racial criminal justice system." 274 One would be hard-pressed to find an opinion, in which a court speaks with approval about the police's use of their discretion to make arrests for these common ulterior reasons. And, some state courts, undeterred by the practical difficulties of pretext doctrine, have explicitly rejected the Whren doctrine, and continue to screen out pretext arrests under their state constitutions' guarantee against unreasonable seizures. ${ }^{275}$ The aspiration of the prosecution principle - to minimize pretextual arreststhus remains discernible in judicial discourse.

\section{Collateral Incentives and the Significance of Explicit Statutory Authorization}

If the prosecution principle remains the dominant standard that defines what it means to use and misuse the discretion to arrest, then collateral incentives are unambiguously incentives to misuse that discretion. The Terry division of labor implies that arrests made explicitly and solely for these collateral purposes are inappropriate. And arrests made primarily for the sake of collateral benefits, even if explicitly for the proper purpose, differ little from those of which courts disapproved in vagueness and pretext cases.

Accepting this claim does not require an assumption that the prosecution principle is the eternal lodestar for arrests. It is, after all, not

274. United States v. Uriostegui, 420 F. Supp. 2d 1260, 1262-63 (M.D. Ala. 2006).

275. See, e.g., State v. Ochoa, 146 N.M. 32, 37, $44-45$ (N.M. Ct. App. 2009) (invalidating pretextual traffic stops under the state constitution); State v. Sullivan, 348 Ark. 647, 652 (2002) ("Unlike the United States Supreme Court, this court has considered pretextual arrests to be unreasonable for over twenty years"); State v. Ladson, 138 Wash. 2d 343, 358 (1999) ("Whren does not define or limit our rights under independent state constitutional safeguards."); State v. Heath, 929 A.2d 390, 402 (Del. Super. Ct. 2006) (rejecting Whren on state constitutional grounds); $c f$. Fertig v. State, 146 P.3d 492, 501 n.3 (Wyo. 2006) (accepting Whren for traffic stops, but noting "a significant distinction between investigative detentions and arrests," and disavowing "inten[t] to change what w[as] previously stated about pretextual arrests"). 
"the law." There is little reason to doubt that the democratic process may broaden the purposes, which the coercive power to arrest may serve, within constitutional limits. I suggest merely that the principle is the default in absence of explicit legislative authorization for pursuing other public aims by means of arrests. The question of which state actors have the authority to revise traditional common law principles limiting the use of state coercion may not have a simple answer. Nonetheless, the case for explicit, transparent revision by democratically accountable state legislatures - over the incidental byproducts of legislation or federal agency directives - is compelling. Federal agency policies that incidentally affect arrest decisions are particularly problematic. Policing and crime control are consistently identified as a paradigmatic example of "what is truly local," 276 both as a legal and practical matter. As Dan Richman points out, "[e]verybody knows to call the local police when reporting or complaining about... crime.",277 "With this responsibility comes at least the potential for some institutional accountability at the local level."278 As Rachel Harmon shows, federal programs that rely on local law enforcement distort the ordinary mechanisms for that accountability. ${ }^{279}$ While the creation of collateral incentives may not run afoul of the constitutional rules, it is certainly in tension with the federalist preference to leave the police power to state control. ${ }^{280}$ In tension with the incentives set up by Secure Communities, Oregon law, for example, prohibits state law enforcement from using agency "moneys, equipment or personnel for the purpose of detecting or apprehending persons whose only violation of law is that they are persons of foreign citizenship present in the United States in violation of federal immigration laws." 281 Some of the LEAs that express approval for automated immigration screening are in states whose political branches express opposition to the program. ${ }^{282}$ The fact that department-

276. United States v. Morrison, 529 U.S. 598, 618 (2000).

277. Daniel Richman, The Past, Present, and Future of Violent Crime Federalism, 34 CRIME \& JUST. 377, 378 (2006).

278. Id.

279. Rachel Harmon, Federal Public Safety Programs and the Real Costs of Policing (July 14, 2014) (unpublished manuscript) (on file with author).

280. See Morrison, 529 U.S. at 618 ("Indeed, we can think of no better example of the police power, which the Founders denied the National Government and reposed in the States, than the suppression of violent crime and vindication of its victims." (citations omitted)).

281. OR. REV. STAT. § 181.850 (2007).

282. For example, the Sheriff of Yates County, NY, a Board Member of the National Sheriffs' Association, signed on to the Association's approval of Secure Communities, see Nat'l Sheriffs' Ass'n, supra note 118, while Governor Cuomo has publicly opposed the program and sought 
level preferences are paramount in encouraging, tolerating, or disciplining individual officers' use of arrest discretion means that it is local, departmental preferences that will determine whether or not the state-level preference is reflected on the ground. ${ }^{283}$

State laws that obliquely affect the purposes for which arrests are made are also problematic, though perhaps less so than federal initiatives. Explicit legislative authorization may legitimately expand arrest authority to purposes beyond those justifying the arrest power as a matter of historical norms. As noted throughout, legislatures have indeed responded to the demands of modernity by authorizing arrests for purposes other than prosecution. Statutes authorize warrantless arrests of the mentally ill as well as to prevent suicide. ${ }^{284}$ Statutes authorize temporary preventive custody of intoxicated persons, sometimes specifying that such detentions shall not be deemed arrests. ${ }^{285}$ Federal and state laws authorize the arrest of material witnesses, if their testimony cannot be otherwise secured. ${ }^{286}$ In addition, legislatures can authorize arrest for conduct that previously could not be criminally prosecuted by creating new crimes. When many vagrancy and loitering laws were declared unconstitutional, legislatures were able to allow police to make effectively many of the same arrests by creating more specific public-order crimes. ${ }^{287}$ Such intentional and transparent legislative broadening of the purposes of arrests is plausibly the result of

unsuccessfully to keep New York from participation. See Letter from Mylan Denerstein, Counsel to Governor Cuomo, to John Sandweg, Counselor to Dep't of Homeland Sec. (June 1, 2011), http://www.governor.ny.gov/assets/Secure\%20Communities.pdf.

283. Indeed, much of the controversy surrounding Secure Communities hinges on its mandatory nature, as some states, as well as localities, resented federal interference with the fates of local noncitizen arrestees. See, e.g., Elise Foley, Obama Faces Growing Rebellion Against The Secure Communities Deportation Program, Huffington Post (Apr. 24, 2014, 4:59 PM), http://www.huffingtonpost.com/2014/04/24/secure-communities_n_5182876.html (describing some state and local measures to thwart Secure Communities).

284. E.g., TenN. CodE ANN. § 40-7-103 (West Supp. 2014) (arrest for suicide prevention); CAL. WELF. \& INST. CODE $\S 5150$ (West Supp. 2014) (authorizing taking into custody of a person who "as a result of a mental health disorder, is a danger to others, or to himself or herself, or gravely disabled" for "up to 72 hours" in a designated facility).

285. E.g., MASS. GEN. LAWS ANN. ch. 111B, § 8 (West 2003) (authorizing protective custody of intoxicated persons for up to 12 hours and noting that such persons "shall not be considered to have been arrested or to have been charged with any crime"); N.H. REV. STAT. ANN. § 172-B:3 (2014) (same for up to 24 hours, and stating that "protective custody under this section is not an arrest").

286. E.g., 18 U.S.C. § 3144 (2008); ME. REV. STAT. tit. 15, § 1104 (2003).

287. See City of Chicago v. Morales, 527 U.S. 41, 67 (1999) (O'Connor, J., concurring) (Although "[a]s the [gang loitering] ordinance comes to this Court, it is unconstitutionally vague," there "remain open to Chicago reasonable alternatives to combat the very real threat posed by gang intimidation" by means of more specific laws.). 
a conscious democratic decision to use arrests to advance new purposes. By contrast, instituting screening regimes that on their face disavow intentions to affect arrest decisions are not likely a result of a transparent deliberation about the legitimate uses of the arrest power. ${ }^{288}$ Collateral incentives are problematic, in short, because they commandeer all the coercive authority that police wield in ordinary arrests towards ends, for the sake of which a democratically-accountable body might not authorize the use of force.

\section{The PRACTICAL CONSEQUENCES OF COLlateral INCENTIVES}

Part III suggests that collateral incentives are problematic as a normative matter because they invite police to misuse the authority to arrest. The practical consequences of such incentives entail the distortion of arrest patterns. This Part turns from jurisprudential background principles to explore these consequences and flesh out the empirical expectations about the effects of collateral incentives on arrest patterns.

As the definition offered in Part II suggests, collateral incentives are incentives to arrest on bases unrelated to arrest quality, and should thus be expected to have an adverse effect on quality at least on some occasions. Moreover, collateral incentives could also be expected to have a redistributive effect on the pool of arrestees. Just as police may make more arrests of members of an identifiable demographic group perceived to exhibit higher rates of offending, ${ }^{289}$ they may be expected to "favor" the group that promises higher expected extrinsic benefits. ${ }^{290}$ As Albert Altschuler puts it with regard to statistical discrimination, "[a] trade-off between distributive justice and efficiency," which for arrests corresponds to arrest quality, "seems inescapable."291 Unlike "pure" statistical discrimination, however, collateral incentives do not "trade off" inequality for arrest quality or vice versa. Indeed, for a subset of arrests, they are likely to result in a compromise with respect to both. ${ }^{292}$

288. See supra notes 9-11 and accompanying text.

289. See supra notes 50-51.

290. See, e.g., Logan, supra note 15, at 1590 ("Trolling and trawling for DNA become even more problematic when one takes into account the demographic and geographic effects of arrests.").

291. Albert W. Alschuler, Racial Profiling and the Constitution, 2002 U. CHI. LEGAL F. 163, 167 (2002).

292. For an exposition that formalizes a similar intuition, see Brian Rowe, Discretion and Ulterior Motives in Traffic Stops: The Detection of Other Crimes and the Revenue from Tickets, BurEAU OF ECON.: FED. TRADE COMM'N (Apr. 2010), http://www-personal.umich.edu/ rowebr/ 
At the same time, the effects on arrest patterns are not uniform or unambiguous. Nor is the misuse of discretion that accompanies collateral incentives limited to the universe of cases where discretion is most commonly believed to be abused - petty offenses, for which arrests are made in the course of proactive street policing. The following sections explain that how precisely collateral incentives shape arrest patterns depends on whether law enforcers care about the intrinsic benefit of arrests at all, and on the underlying distribution of guilt for particular offenses in particular settings.

\section{A. Arrests Made for Extrinsic Benefits}

Collateral incentives have the most unambiguous effect on arrest quality and the composition of the arrestee pool for that subset of arrests, which would simply not be made for the intrinsic benefits of arrests alone. If police are intent on pursuing an extrinsic benefit, be it order maintenance or effecting a deportation, they have good reason to seize without probable cause and be "willing to forgo successful prosecution in the interest of serving some other goal." 293 Such arrests are welldocumented and discussed in scholarship and the media. ${ }^{294}$ For instance, accounts such as Adrian Schoolcraft's, the New York officer who secretly audio-recorded his precinct for months, show that supervisors tell officers to "haul someone in with the intent of voiding the arrest at the end of a shift," or "arrest citizens after having witnessed them doing nothing more than standing around, just to let them go a few hours later with no charges filed." ${ }^{295}$ Issa Kohler-Hausmann's research into New York misdemeanors shows "massively expanded arrests for low-level

pdfs/rowe_ulteriormotives_apr2010.pdf (employing a model of law enforcement to show that seemingly wasteful traffic stops, where no tickets are issued, are rationalized by "the ulterior motive of detecting other crimes").

293. Terry v. Ohio, 392 U.S. 1, 14 (1968).

294. See Alexandra Natapoff, Misdemeanors, 85 S. CAL. L. REv. 1313, 1348 (2012) (“[B]ulkurban policing crimes such as loitering, trespassing, disorderly conduct, and resisting arrest... are ... the kinds of offenses for which police often use high volume arrests to maintain street order or zero tolerance policies.... [S] uch arrests routinely occur without sufficient evidence to support conviction.").

295. Graham Rayman, The NYPD Tapes, Part 2, Village Voice (May 11, 2010), http://www.villagevoice.com/2010-05-11/news/nypd-tapes-part-2-bed-stuy/; see also Bielevicz v. Dubinon, 915 F.2d 845, 849 (3d Cir. 1990) ("it was common knowledge among officers that the charge of public drunkenness could be used to remove from the streets without probable cause a person who was not intoxicated .... [T] he charge was often used to defuse crowd control problems, to detain people found in areas of notorious drug use, to arrest women suspected of prostitution, and to punish anyone who defiantly quarreled with an officer."). 
crimes [since the 1990s] .. [which] did not translate into proportionately higher numbers or rates of misdemeanor convictions." ${ }^{296}$ Unlawful arrests for the sake of the collateral benefit have in fact been brought before the courts, ${ }^{297}$ and reported by practitioners. ${ }^{298}$ For instance, the DOJ investigation of the Maricopa County's Sheriff's Office (MCSO) under the notorious Sheriff Joe Arpaio found that, among other transgressions, MCSO deputies were found to "arrest Latino drivers ... without . . adequate cause" to enforce immigration law. ${ }^{299}$ While these sorts of arrests have been documented most commonly for petty crimes, there have been cases of arrests made for the sake of the collateral benefit for more serious crimes. ${ }^{300}$ In short, when police wholly discount the intrinsic benefits of arrests and pursue collateral benefits, the effect will be to both lower arrest quality and redistribute the pool of arrestees towards identifiable groups perceived more likely to deliver the latter benefit.

\section{B. Arrests for Common Offenses with Clear Probability of Guilt}

Even if police are not wholly indifferent to the core purpose of arrests, however, collateral incentives will affect decisions on the margins. Assume an officer who does value the intrinsic benefits of arrest. Suppose that officer's "arrest threshold" requires a 50\% chance of

296. Issa Kohler-Hausmann, Managerial Justice and Mass Misdemeanors, 66 STAN. L. REV. 611, 641-42 (2014).

297. E.g., United States v. Morales-Puerto, No. 06-30452, 2007 WL 1454953, at *1 (9th Cir. May 16, 2007) (defendant was arrested because police recognized his photo from a circulated noncriminal immigration warrant, and defendant was promptly handed over to ICE custody, and where "[t]he government no longer disputes that ... there was neither probable cause nor a warrant" for the arrest).

298. See Alex Stepick et al., False Promises: The Failure of Secure Communities in MiamiDade County, Research Inst. On Soc. \& ECON. Policy Ctr. FOR Labor RESEARCh \& StUdies, FLA. INT'L UNIV., 9 (Apr. 2013), http://d3n8a8pro7vhmx.cloudfront.net/aijustice/pages/283/ attachments/original/1390429692/False-Promises-The-Failure-of-Secure-Communities-in-MiamiDade-County.pdf?1390429692 (a public defender in Miami-Dade County reported the increase in arrests of Hispanics "for charges we would not normally see," such as "trespassing for sitting on a bus bench," and of which "many are dismissed outright").

299. Letter from Thomas E. Perez, Assistant U.S. Attorney Gen., to Bill Montgomery, Cnty. Attorney, Maricopa Cnty. (Dec. 15, 2011), http://www.justice.gov/crt/about/spl/documents/ mcso_findletter_12-15-11.pdf. The MCSO became involved in immigration enforcement before Secure Communities as part of a $287(\mathrm{~g})$ agreement, and contacting ICE on their own initiative.

300. See, e.g., United States v. Perez-Partida, 773 F. Supp. 2d 1054, 1068 (D.N.M. 2011) (defendant was illegally searched and arrested on cocaine and heroin possession charges after detective saw his Mexican driver's license, actions which were, as the court found, "in part motivated by an immigration-related purpose" because the detective knew defendant would be fingerprinted and his immigration status screened pursuant to current policy). 
legal guilt: that is, his decision rule is to make arrests only when he assess the probability of guilt at $50 \%$ or above, which makes the existence of probable cause reasonably likely.

With that officer in mind, consider a set of offenses, where offenders are common and signals of guilt are readily apparent. Most traffic violations are of this kind. It is commonplace to observe that a law enforcer who is so inclined would be able to stop and arrest just about any motorist for an observed violation, because violations are so common. In such contexts, the probability of guilt is distributed across the locally policed population (i.e., drivers on the road, people out in public in a patrolled area) as depicted in Figure 1. Some people display no signs of violating the law, but those who do, not only demonstrate some signals of guilt, but the signals are unambiguous and clearly over our hypothetical officer's arrest threshold (represented by the solid line).

In such settings, where sufficiently guilty targets are plentiful, police can effectively determine arrest rates and the total number of arrests. The expected intrinsic value and cost of such an arrest does not vary much across potential arrestees. ${ }^{301}$ An expectation of a positive extrinsic benefit thus endows an arrest with a higher value to the arresting officer. This has an effect of moving the officer's decision threshold for making an arrest to some probability of guilt below $50 \%$ (i.e., $50 \%$ - b, represented by the dotted line) for the sub-population for which the benefit is expected, since arrests of "less guilty" individuals are worth the same with the expected benefit as the arrests of the "more guilty" without it. And, this means that of two potential "equally guilty" suspects, the one who promises a collateral benefit would make for a higher value arrest.

301. That is, I presume for the sake of this discussion, that all "traffic offenses" are viewed as of equivalent seriousness or arrest-worthiness by law enforcers; this is clearly not true as a descriptive matter, but the inferences remain applicable if we instead imagine several categories of equivalent offenses. The equivalence of costs across all traffic offenses is a more realistic assumption in the sense that the officer need not expend more effort into investigating or effecting one arrest or another. 


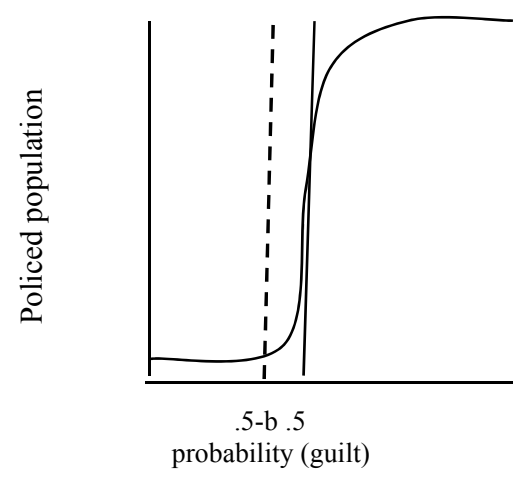

Figure 1. Probability of guilt across the locally policed population.

- officer's arrest threshold without collateral benefit

--- officer's arrest threshold with the collateral benefit

While no other class of violations is as common as traffic violations, all that is required for this decision environment is that offenders are numerous, easily found, and that signals of guilt be manifest. For instance, in areas where drug dealing is widespread, arrests for retail drug sale may present police with similar decisions. To be sure, observing a drug sale directly requires more effort from law enforcers than observing a traffic violation. The effort, however, is roughly the same across the many potential targets. Buy-bust tactics in a setting with many potential targets leaves police free choice of who to target, as Sekhon's account of narcotics policing in Seattle shows. ${ }^{302}$

Although some scholars express concern that common, petty crimes are "evidentiarily weak," 303 selective arrests for these kinds of common crimes need not be weaker than arrests made in the absence of an ulterior purpose. Because the rise in the probability of guilt is steep across the policed population, there are not a lot of suspects whose likelihood of guilt is in between the officer's original decision threshold and his

302. Sekhon, supra note 38, at 1200-03 (describing how the Seattle Police Department's enforcement policies produce disproportionately high rates of arrests of African-American sellers, relative to their likely share of all drug sellers in the city); see also Kohler-Hausmann, supra note 296, at 630 (listing a number of crimes such as drug possession and unlicensed vending of which "[t]he police can find as many instances . . . as they devote the time and resources to find").

303. Natapoff, supra note 294 , at 1334. 
extrinsic-benefit threshold. ${ }^{304}$ In this setting, collateral benefits allow police to make a higher value arrest at a fixed cost. The problem is as Sekhon puts it, "distinguishing among the guilty," 305 where degrees of guilt need not be traded off against collateral benefits. Thus, the predominant effect of collateral incentives for such offenses is to redistribute arrests towards groups expected to deliver the benefit.

There is some evidence that collateral incentives affected these sorts of arrests. The DOJ found, for instance, that Alamance County's Sheriff Terry Johnson directed officers "to arrest all Latinos who commit the traffic infraction of driving without a license," in order to "bring them into the Alamance County Jail to be run through immigration databases, rather than simply issuing them citations." "306 The Latinos so detained were as guilty as non-Latinos arrested for the same offense. The effect of collateral incentives is instead predominantly on relative groupspecific arrest rates. ${ }^{307}$

\section{Arrests for Offenses on Ambiguous Evidence}

For many ordinary offenses, however, manifestly guilty individuals are not as common, and the probability of guilt for a given offense declines across the policed population, as depicted in Figure 2. In many settings, the probability of guilt will be ambiguous, even if the offense itself is relatively common. Some such offenses are encountered in the course of proactive policing, while some come to the attention of the police through a citizen's complaint.

304. That is, the area under the probability-of-guilt curve between a $50 \%$ probability of guilt and some lower probability of guilt, $.5-\mathrm{b}$, which delivers the same benefit when combined with a chance to obtain the extrinsic benefit, is small.

305. Sekhon, supra note 38, at 1172.

306. Thomas E. Perez, United States' Investigation of the Alamance County Sheriff's Office, U.S. DEP'T OF JUSTICE, 6 (Sept. 18 2012), http://www.justice.gov/iso/opa/resources/ 171201291812462488198.pdf.

307. Latino drivers were arrested disproportionately often in Alamance County, as shown by the expert analysis ordered by the DOJ. See John H. MacDonald, Expert Report on The_Alamance County Sheriff's Office (Nov. 15, 2013), http://ncids.com/pd-core/wp-content/uploads/ 2013/05/Expert-Report-on-the-Alamance-County-Sheriffs-Department-John-M-MacDonald.pdf. 


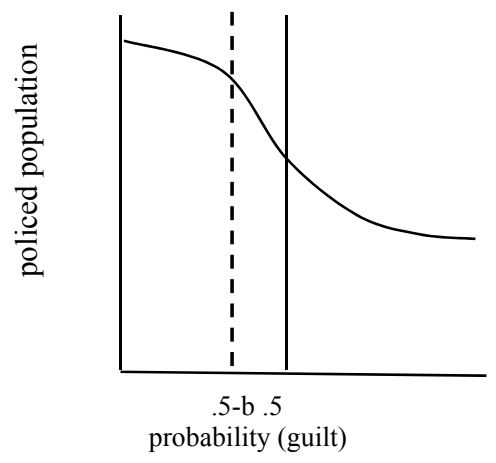

\section{Figure 2. Probability of guilt across the locally policed population.}

- officer's arrest threshold without collateral benefit

--- officer's arrest threshold with the collateral benefit

Consider this ordinary set of cases. Acting on an informant's report, police observe behavior consistent with a drug transaction, but do not directly observe drugs change hands. ${ }^{308}$ A call to the police reports a physical altercation between two neighbors; police arrive and question both men, each of whom blames the other for initiating the fight. ${ }^{309}$ A child makes an allegation of sexual assault against an adult, in the absence of physical evidence. ${ }^{310}$ A police officer asking an individual for identification is handed an unfamiliar identification card, where possession of a false document with intent to defraud is a criminal offense. $^{311}$ All of these cases may or may not support probable cause as

308. See, e.g., Moskos, supra note 32, at 130-35 (describing variations on these facts to demonstrate that arrests for which he, the arresting officer, believed he had probable cause, were declined for prosecution by the prosecutor).

309. For a similar case, see Sheehy v. Town of Plymouth, 191 F.3d 15, 17-18 (1st Cir. 1999).

310. Although victim complaints are said to establish probable cause, courts have noted that this is not so when there are reasons to doubt the veracity of the complaint. See, e.g., Mistretta v. Prokesch, 5 F. Supp. 2d 128, 133 (E.D.N.Y.1998). Cases where victim testimony is the main or sole evidence are not uncommon. See, e.g., Waters v. Clarke, No. 2:11CV00630, 2012 WL 4498916 (E.D. Va. July 3, 2012)

311. See Eagly, supra note 93, at 1183 ("Defense attorneys in Maricopa County[, AZ,] repeatedly described the same scenario: A noncitizen presents a Mexican consular identification card 
a matter of law, and a prosecutor may or may not choose to prosecute them.

In all these cases it is not immediately apparent that evidence puts the likelihood of guilt beyond the officer's arrest threshold. The expectation of a collateral benefit would make the officer more likely to make an arrest, because it would compensate for the possibility that the arrest turns out to be unlawful. Absent extrinsic benefits, an officer will make a judgment and arrest some but not other suspects. The effect of collateral incentives is again to move the officer's evidentiary threshold for arrests below his ordinary threshold (represented by the dotted line) for the sub-population for which the benefit is expected. In this setting, arresting on the basis of the collateral benefit allows police to make arrests of equal value as those of suspects above the arrest threshold at the same cost. By contrast with the offenses depicted in Figure 1, here there is a non-trivial number of suspects whose probability of guilt lies between the officer's original decision threshold and his extrinsic-benefit threshold, and who may be selected for arrests in the expectation of an extrinsic benefit. Thus, for this category of conduct, the effect of collateral incentives will be not only to increase relative arrest rates for groups promising the collateral benefit, but also to decrease the quality of arrests.

Reported case law documents instances where it seems highly likely that collateral incentives played a role in the decision to arrest on ambiguous signals of guilt. For example, in a case which the court characterized as a "close one" on the question of probable cause, ${ }^{312}$ detectives arrested a suspect for attempted delivery of a controlled substance. Detectives observed what they thought was drug-related contact in an area known for drug dealing, searched the defendant, and questioned a passenger in the car, who said she bought heroin from the defendant years earlier. Faced with ambiguous signals of guilt, detectives chose to arrest the defendant. One detective contacted the then-INS. The court found the evidence insufficient for probable cause, and determined that the arrest was "based at least in part on [the defendant's] race," used as an indicator of illegal presence in the

during questioning from the police only to be arrested for document fraud because the foreign document looks 'suspicious."”).

312. United States v. Ortiz-Hernandez, 427 F.3d 567, 575 (9th Cir. 2005) ("Although the facts make this call a close one, we cannot say that the district court clearly erred when it ruled that considering the totality of evidence," that "the evidence was insufficient to establish probable cause"). 
country. ${ }^{313}$ The court's perception was supported by the fact that the police did not arrest defendant's companion, "a non-Hispanic, who failed to signal a turn, was driving with a suspended license, and was an admitted heroin addict in possession of drug paraphernalia." 314

Published cases, where courts make confident conclusions about the officer's motivation for the arrest are not frequent. And legal challenges to such arrests are few and far between in the immigration screening context: if the officer was correct and the arrestee is placed in deportation proceedings, it will usually do him no good to challenge the arrest. ${ }^{315}$ Although courts may not see very many such cases, arrests made under similar conditions should be entirely expected for those law enforcers who value the collateral benefit.

\section{Arrests Requiring Investigative Effort}

When probable cause is not immediately apparent and the set of plausible suspects is small (or the suspect is unique), the arrest decision may be postponed until further investigation cements or dispels suspicion. The guilt probability curve for this set of crimes also declines across the policed population, and more steeply so (Figure 3), with even fewer suspects at the high probability-of-guilt end. Because guilt is not readily apparent, these cases require some investigation. Sometimes police focus on a single, identified perpetrator. But arrests are often made, and subsequently prosecuted, in cases without strong identifying information as to the suspect. ${ }^{316}$

313. United States v. Ortiz-Hernandez, 276 F. Supp. 2d 1113, 1117 (D. Or. 2003), aff'd in part, dismissed in part, 427 F.3d 567, 580 (9th Cir. 2005).

314. Id.; see also Puc-Ruiz v. Holder, 629 F.3d 771, 775-76 (8th Cir. 2010) (arrest of defendant on ambiguous evidence of violating a municipal alcohol ordinance, which was found to lack probable cause, was followed by police-initiated contact to ICE to verify defendant's immigration status).

315. See supra notes $94-97$ and accompanying text.

316. See Steven G. Brandl \& James Frank, The Relationship between Evidence, Detective Effort, and the Disposition of Burglary and Robbery Investigations, in THE POLICE IN AMERICA: ClASSIC AND CONTEMPORARY READINGS 300, 307 (Steven G. Brandl \& David E. Barlow, eds., 2004). 


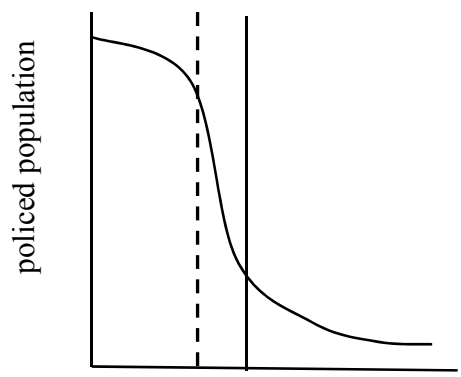

$.5-\mathrm{b} .5$

probability (guilt)

\section{Figure 3. Probability of guilt across the locally policed population.}

- officer's arrest threshold without collateral benefit

--- officer's arrest threshold with the collateral benefit

These kinds of arrests are typically made in the course of "reactive" policing. There is a measure of scholarly consensus that policing described as proactive or preventative is less constrained by the core constitutional limits on searches and seizures, but that these limits function better when it comes to reactive or investigative policing of serious crimes. ${ }^{317}$ Investigation-heavy felony arrests are thus frequently described as non-discretionary. ${ }^{318}$ Likewise, detectives involved in the kinds of serious crimes that require investigation are typically characterized as focused on convictions and more susceptible to legal

317. See, e.g., Eric J. Miller, Role-Based Policing: Restraining Police Conduct "Outside the Legitimate Investigative Sphere", 94 CAL. L. REV. 617, 621 (2006) ("The attempt to limit police authority through prospective constitutional (and other) norms that control the police's ability to search, seize, and interrogate suspects is properly confined to the police's investigative role. These limits do not work well to regulate the police's authority when engaged in upholding public order and preventing crime."); Wayne R. LaFave, The "Routine Traffic Stop" from Start to Finish: Too Much "Routine," Not Enough Fourth Amendment, 102 Mich. L. REv. 1843, 1852 (2004) ("When it comes to such common criminal offenses as burglary, theft, and assault, the quantum-of-evidence requirement for making a seizure itself serves as a reasonably effective means of ensuring that only those who should be apprehended are seized.").

318. E.g., Erik Luna, Principled Enforcement of Penal Codes, 4 BUFF. CRIM. L. REv. 515, 55152 (2000) ("If there is probable cause to believe that a suspect has committed a murder, for instance, the police will invariably arrest and the prosecutors will invariably charge."). 
controls. ${ }^{319}$ The proactive/reactive, or preventive/investigative dichotomy should not lead to the sanguine conclusion that collateral incentives will not affect this category of arrests.

For any given crime and any given suspect, police have the choice of arresting on existing evidence or continuing to investigate (i.e., incur higher costs) with the expectation of increasing the quality of the arrest. $^{320}$ Even detectives working serious cases decide how much effort to devote to a case, whether to soft-pedal, and when to stop investigation and make an arrest. ${ }^{321}$ In this context, setting the level of investigative effort on the basis of the collateral benefit allows police to make arrests of equal value as those of suspects above the arrest threshold at lower cost.

Reported cases document instances where it seems highly likely that collateral incentives presented by immigration screening affected investigative effort. In United States v. Bowley, ${ }^{322}$ a police sergeant was investigating a series of armed robberies. He received information from an informant that Bowley was involved in these and additional serious crimes. When in the course of his investigation, the sergeant and his partner learned that Bowley was likely illegally in the country, they arrested him, rather than continuing to investigate the crimes. ${ }^{323}$ The court later determined that while the police had reasonable suspicion with regard to Bowley's involvement in the robberies, it did not amount to probable cause. ${ }^{324}$ Bowley was suspected of a number of serious crimes, of the kind that most officers would presumably value highly and

319. E.g., Myron W. Orfield, Jr., Deterrence, Perjury, and the Heater Factor: An Exclusionary Rule in the Chicago Criminal Courts, 63 U. Colo. L. REV. 75, 86 (1992) ("The aim of specialized units such as homicide, burglary or narcotics is to obtain convictions. Officers are rated both formally and informally on their ability to achieve this goal," and have "strong incentives to stay within the bounds of the Fourth Amendment").

320. There is evidence that investigative effort increases the quality of arrests. See Brandl \& Frank, supra note 316 , at 306-07.

321. See, e.g., Steven G. Brandl, The Follow-up Investigation as a Decision Making Process: An Observational and Protocol Analysis, 9 J. POLICE \& CRIM. PSYCHOL. 20 (Oct. 1993). Former police officer's Adrian Schoolcraft's recordings of the NYPD's 81st Precinct, for example, demonstrates how detectives and officers seek to scuttle the fate of potentially serious crimes: they call the victim and question them closely on the details of their complaint, and asking intimidating questions about the victim's own veracity or criminal history. See also Graham Rayman, The NYPD Tapes: Inside Bed-Stuy's 81st Precinct, Village VoICE (May 4, 2010), http://www.villagevoice.com/2010-0504/news/the-nypd-tapes-inside-bed-stuy-s-81st-precinct/5/.

322. United States v. Bowley, No. CRIM. 2004/0169, 2005 WL 1398632 (D.V.I. June 8, 2005), rev'd and remanded, 435 F.3d 426 (3d Cir. 2006).

323. Id. at *1.

324. Id. at $* 2$. 
seek to clear. Nonetheless, once officers learned that he was likely deportable, they decided to arrest on what they must have realized was not clearly sufficient evidence: they were following a tip by an informant, whose veracity and basis of knowledge could not be taken for granted. ${ }^{325}$ Were Bowley a citizen, it seems likely that officers would continue his investigation before making an arrest.

While police probably value the intrinsic benefits of arrests for serious crimes that demand investigation, there is evidence that extralegal, irrelevant considerations influence investigative effort and arrest decisions even for these crimes. Studies show that extralegal factors such as victim's and offender's race affects how much investigative effort is put into clearing recorded crimes and whether an suspect is ultimately arrested. ${ }^{326}$ Studies likewise suggest that extralegal factors affect arrest quality: one study finds that arrests of Black suspects are dismissed more often than arrests of White suspects-not only for "discretionary" minor crimes, but also for serious violent crimes. ${ }^{327}$ If dismissal rates correlate with arrest quality, these results suggest that race influences arrest decisions beyond what is warranted by the evidence. It is then not unreasonable to think that collateral incentives could be as influential as other extralegal factors.

In sum, if we believe that officers maximize arrest value, faced with limited resources and numerical pressures, it should be expected that collateral incentives influence arrest decisions. These incentives introduce redistributive pressures across all arrests to which they attach that are unwarranted by the underlying offense rates. Furthermore, for three categories of arrests - those for which officers are indifferent to intrinsic value, those which involve ambiguous guilt, and those that call for investigative effort - these incentives conduce to lower arrest quality.

325. See id. at *1-2.

326. See, e.g., Aki Roberts \& Christopher J. Lyons, Victim-Offender Racial Dyads and Clearance of Lethal and Nonlethal Assault, 46 J. RES. CRIME \& DELINQ. 301, 312-13 (2009) (finding that homicides involving non-White offenders and White victims were most likely to be cleared, and those involving White offenders and non-White victims least likely); Lisa Stolzenberg et al., A Multilevel Test of Racial Threat Theory, 42 CRIMINOLOGY 673 (2004) (finding that violent crimes involving White victims and African-American offenders were most likely to be cleared by an arrest in segregated cities).

327. Tomic \& Hakes, supra note 52, at 135 (“dismissal rates are 1.4 and 2.4 percentage points higher [for Black arrestees for violent and high-discretion crimes, respectively], suggesting that at the margin, the charges against Blacks are more likely to be weak or false"). 


\section{E. The Problem of Systematic Evidence}

One might justifiably ask whether collateral incentives are likely to matter for more than the handful of cases offered to illustrate the plausibility of the expectations above. Although, as I argue, there are good reasons to expect collateral incentives to have real consequences, systematic evidence is indeed scarce. In part, this is because these screening regimes are sufficiently recent that a body of robust empirical research has not yet accumulated. ${ }^{328}$ A few studies are suggestive. An analysis of Irving, TX, found that arrests of Hispanics for petty offenses increased considerably after a pre-Secure Communities in-jail screening regime was implemented in the jurisdiction, which could not be reasonably explained by changes in lawless behavior by Hispanics. ${ }^{329}$ Another study analyzed a sample of deported immigrants identified through Secure Communities, finding that Latinos are overrepresented in the sample relative to their share in the estimated unauthorized immigrant population, and that the differences cannot be explained by their higher criminal activity. ${ }^{330}$ Yet another study examined the language used in traffic arrest reports before and after Davidson County, $\mathrm{TN}$, entered into a $287(\mathrm{~g})$ agreement with DHS, and found that country of origin, language, and immigration status were significantly more likely to occur in reports after the county implemented the immigrationenforcement partnership. As these factors are unrelated to probable cause, their presence signals greater law enforcement attention to immigration status, after such becomes relevant to post-arrest outcomes. $^{331}$ The experiences of Maricopa and Alamance Counties Sheriff's Offices noted above also suggest that access to immigration information mattered for those LEAs. ${ }^{332}$

More fundamentally, however, subjecting these expectations to empirical scrutiny will be a difficult task. As with anything that influences decisions at the margins, the effects of any one set of

328. Indeed, some of the DNA collection laws that have been passed, have not yet been implemented due to resource constraints. See Samuels et al., supra note 67, at 77.

329. Trevor Gardner II \& Aarti Kohli, The C.A.P. Effect: Racial Profiling in the ICE Criminal Alien Program, 2009 The Chief Justice EARL WarRen InSTIT. ON RACE, ETHNiCity \& Diversity 1,3-4, available at $\mathrm{http}: / / \mathrm{www}$. law.berkeley.edu/files/policybrief_irving_FINAL.pdf.

330. Kohli, et al., supra note 14 .

331. Katharine M. Donato \& Leslie Ann Rodríguez, Police Arrests in a Time of Uncertainty: The Impact of 287 (g) on Arrests in a New Immigrant Gateway, AM. BEHAV. ScIENTIST, 58(13), 1696-1722 (2014).

332. See supra notes 299 and 306 and accompanying text. 
collateral incentives may be too faint to be detected. Effects may be undiscernible, even if they are not substantively trivial. New collateral incentives layer on top of preexisting incentives, and signals that a suspect might deliver one collateral benefit may be correlated with a signal of another such benefit - and may reinforce extant demographic inequalities in enforcement. This makes consequences of any single policy innovation difficult to detect empirically in a way that allows an inference of a causal connection. For instance, incentives for pretextual enforcement actions and targeting of Latinos were already in place for some LEAs before the implementation of Secure Communities. While both earlier and later policy innovations may have influenced arrest decisions at the margins, the activation of the latter program might not trigger clearly discernible, substantial changes in arrest patterns. ${ }^{33}$ The accretion of collateral incentives has the potential to transform dramatically who is targeted for arrest and what legal guilt means, without our ability to notice the transformation at any particular point in time. Criminal procedure scholars, such as Stephanos Bibas and Eric Luna, advocate for transparency, as a way to keep police accountable. ${ }^{334}$ Unless transparency can elicit the ulterior motives with which law enforcers act, having access to the data of policing may still not allow us to detect "statistically insignificant" effects of gradual, multiple innovations. The potential impotence of transparency in this regard undermines the force of the Supreme Court's claim in Atwater that "failing" the normal constraints on arrest discretion discussed above, there is always "political accountability[] of most local lawmakers and law-enforcement officials." 335

333. See Elina Treyger et al., Immigration Enforcement, Policing and Crime: Evidence from the Secure Communities Program, 13 CRIMINOLOGY \& PUB. POL'Y 285, 312-13 (2014) (finding no effects on arrest rates of Whites (including Hispanics), following the activation of Secure Communities across over 300 metropolitan police departments, but concluding that the meaning of these results is ambiguous, because the marginal impact of an additional set of incentives to target Hispanic suspects on police departments with pre-existing incentives may be too faint to be detected statistically).

334. Erik Luna, Transparent Policing, 85 IOwA L. REV. 1107, 1108 (2000) ("Even harmful abuses of discretion can be dealt with through legal and political recourse - as long as the behavior is visible to the affected individual and the citizenry."); Stephanos Bibas, Transparency and Participation in Criminal Procedure, 81 N.Y.U. L. REV. 911, 917 (2006) ("Greater transparency ... facilitate[s] the monitoring of insiders by checking their self-interests and agency costs.").

335. Atwater v. City of Lago Vista, 532 U.S. 318, 353 (2001). 


\section{CONCLUSION}

Secure Communities and DNA collection laws are not the first collateral incentives attached to arrests, nor will they be the last. This Article put forth a normative and practical case against an uncritical embracing of such policy innovations. The concern about collateral incentives to arrests is a special case of more general concern about the way discretion is exercised, expressed by scholars such as David Sklansky and Eric Miller, among others. ${ }^{336}$ Sklansky worries about the rise of "ad hoc instrumentalism," which he defines as "a manner of thinking about law and legal institutions that downplays concerns about consistency and places little stock in formal legal categories, but instead sees legal rules and legal procedures simply as a set of interchangeable tools." ${ }^{337}$ Ad hoc instrumentalism describes a state of affairs whereby state agents choose, on an ad hoc basis, a legal tool at their disposal from a menu of criminal and civil sanctions, which they deem the most useful means of neutralizing a problematic person. Attaching collateral incentives to arrests invites police to adopt Sklansky's ad hoc instrumentalism when it comes to the most coercive tool at their disposal: an arrest may, depending on the officer's judgment, facilitate prosecution - or it may serve to deport a non-citizen, to solve a cold case, or to deter individuals from future criminal activity. Miller's proposal to institutionally separate investigative from preventative, or caretaking roles stems from similar concerns about the instrumental use by the police of low-level encounters meant for caretaking, to investigate and prosecute more serious crimes. ${ }^{338}$ Only an institutional separation, he argues, will remove the constant temptation by the police to "escalate" Terry-level encounters into more coercive encounters with serious penal consequences. $^{339}$ To put Miller's thesis in the terms employed in this article, there are no effective means to enforce the Terry division of labor between custodial arrests, intended to enable prosecution, and brief seizures, which may serve a host of non-prosecutorial purposes. For Sklansky, the fundamental problem with ad hoc instrumentalism is in its tension with the rule of law, and in its undermining of accountability.

336. David Alan Sklansky, Crime, Immigration, and Ad Hoc Instrumentalism, 15 NEw CRIM. L. REV. 157 (2012); Miller, supra note 317.

337. Sklansky, supra note 336, at 161.

338. Miller, supra note 317 , at 664 (observing that "[t]he central problem is that the police attempt to switch or conflate roles, from preventative policing of public order to investigative policing drug crime").

339. Id. 
For Miller, the practice of using preventative policing for investigative purposes undermines the legitimacy of the police, especially in minority communities. All of these concerns are implicated when collateral incentives transform arrests into vehicles for the attainment of goals other than criminal prosecution. The kind of pretextual enforcement that is facilitated by collateral incentives is in tension with rule-of-law ideals insofar as these dictate that state coercion should be exercised against individuals in accordance with stable rules and for transparent purposes: it licenses, in Sklansky's words, "a kind of petty tyranny." 340 Accountability is undermined when the purposes that arrests serve are incidentally broadened by laws and regulations not explicitly intended to alter the contours of the arrest power by a democratically accountable body. And the pretextual uses of arrests which collateral incentives invite will certainly do little to improve the perception of police legitimacy in the communities most liable to experience the practical consequences of these policies.

While it is a tall order to ask for a remaking of modern policing so as to root out ad hoc instrumentalism or separate the investigative and caretaking roles, it may be a slightly less tall one to ask for caution with regard to the use of the most coercive tool at police's disposal. This is especially so if the public policy goals achieved by attaching collateral incentives may be substantially furthered otherwise. State legislatures may not be able to explicitly broaden the purposes of arrests to encompass the two sets of interests discussed here. For instance, states are constitutionally precluded from authorizing arrests by simply criminalizing civil violations of the immigration laws. ${ }^{341}$ And a law that authorizes arrests or detentions only to collect DNA samples in absence of individualized suspicion would likely be unconstitutional. However, there are ample and adequate alternate means of advancing the same public goals. Notably, most, if not all, of the advantages of database screening regimes may be captured by maintaining screening and analysis of fingerprints and DNA at conviction, which ensures that state actors are committed to the prosecution of the crime of arrest by the screened individuals and lessens the distortion of arrest incentives. Indeed, all states have laws that mandate the collection of DNA from

340. Sklansky, supra note 336, at 210.

341. Arizona v. United States, 132 S. Ct. 2492, 2502 (2012) ("Even if a State may make violation of federal law a crime in some instances, it cannot do so in a field (like the field of alien registration) that has been occupied by federal law."). 
those convicted of certain crimes. ${ }^{342}$ The value-added of screening at arrest is to pick those individuals who will not be convicted of the crime of arrest, or will be convicted of a lesser crime not qualifying for collection, where the crime of arrest does qualify. This group of arrestees appears on their face to be the least valuable, least criminally prone, additions to the DNA databanks. ${ }^{343}$ Similarly, screening fingerprints against the DHS database at conviction-or, simply not releasing information discovered at arrest to local LEAs until conviction-would still substantially advance the goal of identifying criminal aliens. While post-conviction screening may fail to detect a few dangerous criminals, who happen to be arrested but not prosecuted, there is little evidence that their numbers are significant. ${ }^{344}$ Even if screening at conviction solves fewer cold cases or catches fewer deportable noncitizens, it should be clear that any incremental value added by on-arrest screening is no mere windfall to society that results in the course of police activities that would have occurred in any case. Whatever the incremental benefit provided by on-arrest screening, the diversion of arrests from their historic, primary purpose is too steep a price to pay for it.

342. "Forty eight states require the collection of DNA for any felony conviction and 42 states require the collection of samples for at least some misdemeanor convictions. New York and Wisconsin have the broadest convicted offender collection policies, taking samples from those convicted of all felonies and misdemeanors." NCSL, supra note 47.

343. See Samuels et al., supra note 67 , at 79 (explaining why it is difficult to quantify the additional benefits of collecting DNA from arrestees).

344. Judging by the criminal convictions of non-citizens removed prior and post- Secure Communities, the program did not significantly increase the detection of serious criminals. See Treyger et al., supra note 333, at 293-94 (reviewing evidence that "insofar as the phasing in of Secure Communities resulted in more criminal alien removals, the expansion is primarily among the less serious criminals"). 